\title{
Central America and El Salvador: The History of Telecommunication Services, Regulation, and the Digital Divide
}

by

\author{
Henry Guardado
}

A thesis submitted to the Faculty of Graduate and Postdoctoral Affairs in partial fulfillment of the requirements for the degree of

Master of Arts

in

Communication

Carleton University

Ottawa, Ontario

(C) 2015, Henry Guardado 


\begin{abstract}
This thesis examines how El Salvador has addressed the digital divide against its own aims and against those of other Central American countries - Costa Rica, Nicaragua, Guatemala, and Honduras. It does this by, first, exploring the historical development of telecommunication services in the region from the mid-1800s to 2013. Second, drawing on literature and data from each country, as well as the International Telecommunications Union (ITU) and the World Bank, it evaluates how government policies have addressed the divide by examining the uptake of fixed-line, mobile phone, and internet services in the region. The evidence shows that sector liberalization in the region has yielded mixed results: while mobile phone services have expanded, fixed-line and internet services remain largely under-developed. Ultimately, this thesis finds that weak policymaking in El Salvador and the rest of the Central American countrieswith the exception of Costa Rica—-have led to unfulfilled universal service goals.
\end{abstract}




\section{Acknowledgements}

This thesis would not have never taken flight without the support and guidance from many. First, I would like to thank my supervisor, Dwayne Winseck. His never-ending enthusiasm and passion for the political economy of communication factored heavily in my decision to enter this Masters program. Thank you, Dwayne, for your continuous support. I would also like to thank Merlyna Lim for lending her brilliant mind to my committee. A special mention goes out to the entire Communication Studies faculty for maintaining a closely-knit, warm learning environment.

Second, I would like to express my gratitude toward my colleagues, particularly those in MA1 and MA2. Your company, laughs, and countless rides back to Barrhaven (Leena and Alex) were appreciated during the busiest times of the year. I would also like to thank my colleagues at Health Canada for being flexible with my work schedule.

Third, I would like to thank my Barrhaven friends for putting up with my anti-social behaviour and for taking me outside of my "thesis-bubble" with stupid jokes when I needed it most. James, Ben, Erdit, Grouch, Jipson, Emma, Vanessa, Hillary, Breen - thank you. I would also like to thank those who took the time to read over this thesis and provided laughs along the way, including those at "Waffles R Stoopihd" (Sam, Windy, James, Bharath) and Courtney.

Lastly, I could not have done this without my family. I dedicate this thesis to my mom and dad who have supported me and have kept food in my fridge since day zero. I am lucky to have such hard-working and perseverant role models. Gracias por su apoyo. I would also like to thank my three brothers, David, Luis, and Alex, and my family in Ottawa, Melbourne, and Texas for their unending support and for keeping me sane throughout the last 12 months. Lastly, my gratitude goes out to my cousins in El Salvador who, despite being thousands of kilometres away, have been at my side throughout this year-long endeavor. Les quiero mucho. 


\section{Table of Contents}

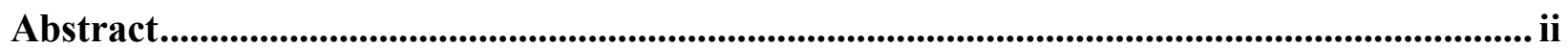

Acknowledgements ............................................................................................................................. iii

List of Tables .................................................................................................................................................. vi

1 Introduction: Why does the Digital Divide Matter?.................................................................. 1

1.1 Concepts: The Digital Divide, Universal Services, and Telecom Reform........................ 3

1.2 Research Methodology/Process ………………….................................................... 15

1.3 Organizational Framework of the Thesis …………................................................. 18

2 The State and Markets: The Shaping of Telecom Policies.................................................. 20

2.1 The Political Economy of Telecommunication: Competing Theoretical Approaches .. 21

2.2 Reasons to Regulate Telecommunication Markets ...................................................... 26

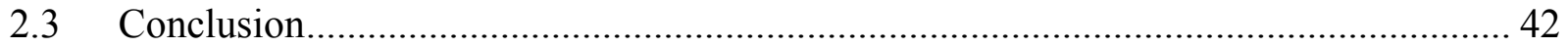

3 Central American Telecommunication: The Early Days of Military Rule ..................... 44

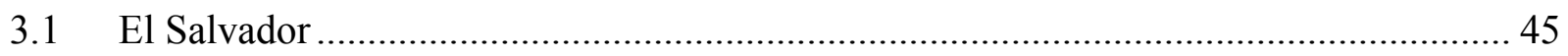

3.1.2 The Birth of ANTEL ………………………………………………………………....51

3.2 Guatemala

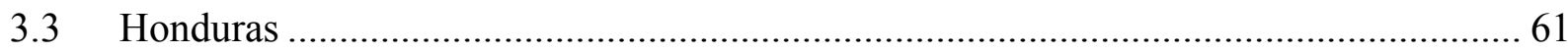

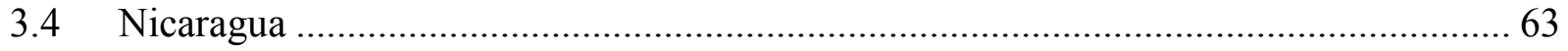

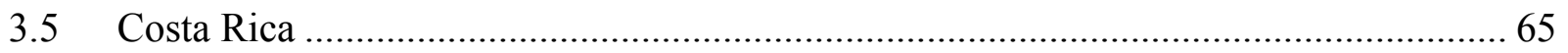

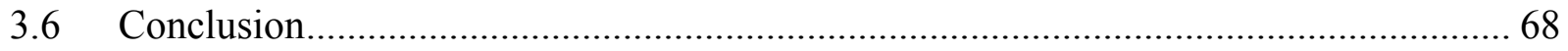

4 Telecommunication Policy Reform in Central America, 1979 - 2013: Change or Déjà Vu? 70

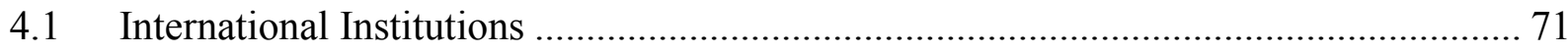

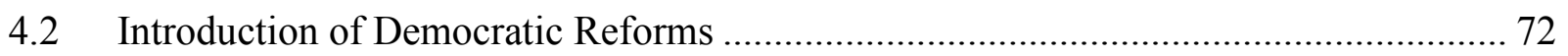




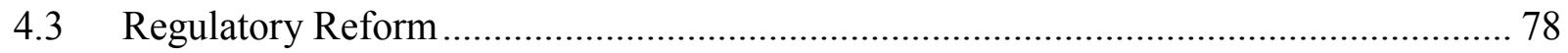

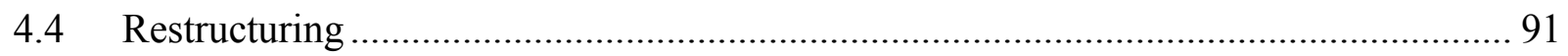

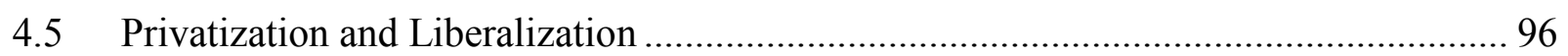

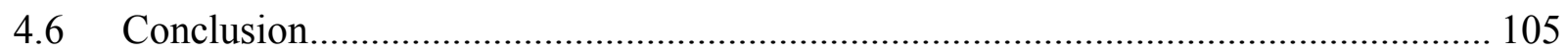

5 Spreading the Message: Universal Service Funds and Communication Services ...... 107

5.1 Universal Service Policies................................................................................. 108

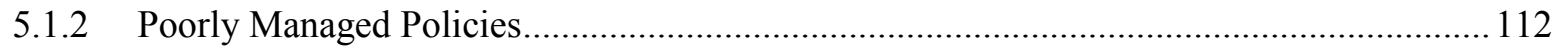

5.1.3 Costa Rica: Universal Service with Moderate Successes .............................................. 118

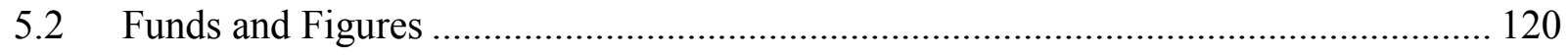

5.3 How Has El Salvador Done? ............................................................................. 129

6 Conclusion: Yesterday's Seeds, Today's Weeds .......................................................... 133

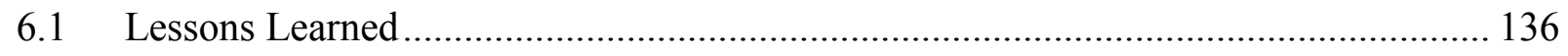

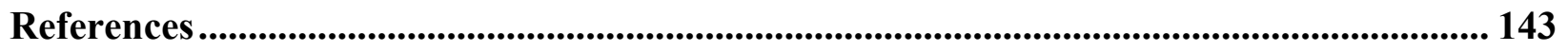




\section{List of Tables}

Table 1.1: Annual GDP per Capita (US Dollars) ....................................................... 6

Table 1.2: Prepaid Mobile Phone Phone - Price of a One-Minute Local Call (off-peak, off-

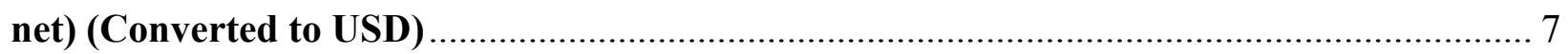

Table 1.3: Fixed (wired)-broadband monthly subscription charge (converted to USD)/

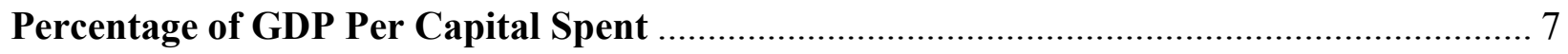

Table 1.4: Monthly subscription for residential telephone service (converted to USD)/

Percentage of GDP Per Capita Spent ............................................................................ 7

Table 2.1: GINI Coefficient by Country since 1990................................................ 31

Table 3.1: Estimated total number of Phones/Estimated phones per 100 people (1925) ..... 49

Table 3.2: Total Number of telephones/telephones per 100 people ................................ 50

Table 3.3: Total Number of Phone Lines/Phone Lines per 100 people............................. 55

Table 4.1: Annual Investments in Telecommunication Services (Million US Dollars) ........ 75

Table 4.2: Total Number of Phone Lines/ Phone Lines per 100 People............................. 76

Table 4.3: Fixed-line Subscriptions, Waiting lists, and Public Payphone Penetrations in

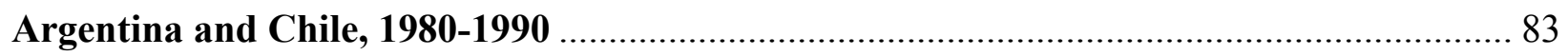

Table 4.4: Total Mobile Phone Subscriptions/ Mobile Phone Subscriptions per 100 People

Table 4.5: Central American Telecom Regulators and Year of Creation ......................... 91

Table 4.6: Dominant Telephone Operators in Central America ...................................... 98

Table 5.1: Creation of Universal Service Funds and Regulatory Bodies (Year) .............. 109

Table 5.2: Total amounts collected and disbursed (USD) ...................................... 111

Table 5.3: Universal Service Fund Targets .............................................................. 119 
Table 5.4: Fixed Telephone Subscriptions per 100 People

Table 5.5: Public Payphones per 1000 people 122

Table 5.6: Percentage of Mobile Services that are Prepaid 123

Table 5.7: Mobile Phones per 100 people 124

Table 5.8: Percentage of Individuals using the Internet 124

Table 5.9: Percentage of Households with Internet 125

Table 5.10: Fixed-broadband Subscriptions per 100 people 126

Table 5.11: Wireless-broadband subscriptions per 100 people 127

Table 5.12: Country IDI Rank in the World 128

Table 6.1: Summary of Findings . 141 


\section{Introduction: Why does the Digital Divide Matter?}

E-mailing through computers. Conference-calling through telephones. Texting through mobile phones. Beneath the motherboards and prices of each technology is a concept that has transcended space and time; one which does not require hardware or infrastructure:

communication. Communication, at its core, is the exchange of ideas which are comprised of the "information, knowledge, and culture [that] are central to human freedom and human development" (Benkler, 2006, p. 1). Telecommunication services facilitates this exchange. As telecommunication services have evolved, from the post office to the internet, so too have information and communication technologies (ICTs) which have allowed us to expand our social, political, and business networks.

However, behind the use and access to these technologies are much larger economic and political forces which affect their access. One could look to Central America, where in the mid1990s, after decades of state-owned telecommunication enterprises, telecommunication sectors undertook liberalization initiatives. For the Central American country of El Salvador, this has meant a political history comprised of an era of military dictatorship followed by a bumpy transition to democracy. Telecommunication services have been important in the development of both eras: in the former, networks were wholly owned by the military state which allowed it to pursue its own economic objectives while neglecting the social needs of its citizens. In the latter, democratic reforms paved the way for privatization and liberalization initiatives which were thought to bring wider access, better-quality services, and social and economic developments to the country. In both eras, the question of the access divide, later referred to as the "digital divide", existed in the backdrop, and whether or not more could be done to address it. 
Thus, this thesis addresses the following question: how has El Salvador's telecommunication regulator addressed the digital divide? And how successful has it been, against its own aims, relative to other Central American countries and in relation to international best practices?

El Salvador's telecommunication regulator, the Superintendencia General de Electricidad y Telecomunicaciones' (or SIGET) mission statement is "to encourage access and to guarantee use of public...telecommunication services for the population" (SIGET, 2009). For SIGET to fulfil this objective, it must tackle the notion of "digital divide." The "digital divide" is a term that has its origins in the United States' postal service (John, 2012), but which in the present day is broadly defined as "the inequality between people and places in access to and use of information and communication technologies [ICTs]" (Castree et al., 2013) or "the study of diffusion of innovations" (Hilbert, 2011). Underlining the definition is the issue of social marginalization.

This thesis contributes to the current body of literature in two ways. First, it outlines the history of telecommunication development in five Central American countries-Guatemala, Honduras, Nicaragua, Costa Rica, and El Salvador. Before these countries became independent states, they were joined together under the Federal Republic of Central America after having separated from the Spanish empire in 1821. Therefore, the history covered in this thesis includes the time period from after the federation's dissolution in 1838 (Bull, 1999) to where the most recent data is available, in 2013.

Second, while there is a large body of work that addresses the issue of the digital divide with respect to developing countries as a whole, there are few studies addressing it specifically in 
Central America, let alone El Salvador. Literature on "South American" and "Latin American" countries exists, but the countries of this thesis are either not covered well in the literature (or lack critical analysis) or are grouped in with more economically developed Latin American countries, such as Mexico and Argentina, when they are addressed. Thus, this thesis contributes to a small body of literature, composed of scholars such as Benedicte Bull (2005), Pedro Raventos (1998), and Brunilda Funes (2002). This thesis addresses this gap by focusing on the historical development of telecommunication services in El Salvador and the Central American region and how this has affected digital divide. Moreover, it analyzes what has been done to address such issues, by whom, and with what effects.

\subsection{Concepts: The Digital Divide, Universal Services, and Telecom Reform}

When confronted with the digital divide, analysts suggest that views are split with respect to measuring it, and whether, if it exists, anything should be done about it. I will outline these perspectives in this section.

Lisa Servon (2002) argues that the digital divide is an issue worthy of addressing and defines it as one encompassing three overarching themes: 1) the divide between those who have access to ICTs and those who do not, 2) the divide in ICT literacy, and 3) the kinds of available content for ICT usage. She suggests that five factors allow the divide to persist: 1) market forces, which make access to ICTs expensive, 2) unequal investment in infrastructure, as investments into high-quality infrastructures are lower in rural areas, 3) discrimination, as middle/upper class white men are more likely to have access than the rest of the population, 4) insufficient policy efforts, where policymakers lack an understanding of the issue, and 5) an overall lack of people's interest to access and create content (pp. 8-10). 
Martin Hilbert (2011) suggests that the digital divide has been understood by scholars as a concept that addresses: 1) the kinds of ICTs in question; 2) the choice of subject, or the legitimacy of the subject; 3) diverse attributes of the chosen subjects; and 4) levels of adoption (p. 715). He suggests that because the degree of the divide is different across countries, there is no universal definition of the "digital divide," but notes that policies should be made not by "reducing the heterogeneity in outlooks, but by better understanding and keeping track of communalities and differences among the priorities of diverse actors and their definitions" ( $p$. 733). His definition suggests that there is no "one size fits all" solution to the divide; policies and initiatives should be made on a country-by-country basis.

One policy solution put forward by scholars to bridge the divide are universal service initiatives. These can include either universal service policies or universal access policies. Universal service policies differ on a country-to-country basis as they are based on the needs of a population. Eli Noam (1994) writes that a universal service policy is designed to "spread telecommunications to most members of society, and to make available, directly or indirectly, the funds necessary" to fulfill this need. As ICTs have developed, so have scholars' opinions around universal services. Patrick Xavier (2008) provides a more recent definition, explaining that they "[refer] to the provision of telecommunications services to all households within a country, including those in rural and remote (high cost) locations" (p. 21). Peter Stern and David Townsend (2007) focus on the affordability aspect of universal service, writing that "absolute universal service is achieved when a given telecommunications service is affordable to $100 \%$ of individuals or households" (p. 8). Universal access policies are ones that "seek to guarantee access to telecommunications infrastructure, sometimes on a shared basis" (p. 21). Services under universal access policies are not required to be connected to a home. 
The literature on "universal service" suggests that the concept has its origins in the US postal system with the creation of The Post Office Act of 1792 which sought to make postal facilities available at affordable prices to all. The goal to bring 'intelligence to every man's doorstep' by facilitating the circulation of newspapers in the US (John, 2010, p. 19). The term, however, was first used in the context of telephony when Theodore Vail (who worked with Bell Telephone Company in the US) used it as a marketing tool to sell home telephones (King, 2011, p. 43). Its framework was later introduced in US legislation by way of the Telecommunications Act of 1934. The act created the Federal Communications Commission,

for the purpose of regulating interstate and foreign commerce in communication by wire and radio so as to make available, so far as possible, to all the people of the United States [...] a rapid, efficient, Nation-wide, and world-wide wire and radio communication service with adequate facilities at reasonable charges... (U.S. Code, 1934)

John King (2011) interprets this legislation as meaning that "everyone should have telephone service - that the service should be universal" (p. 46). Indeed, the literature generally shows this to be the interpretation that many scholars have adopted up until the present day. Established, more "official" universal service policies gained popularity during the mid-1990s; it was at this time when Latin American countries began introducing their own kinds (Hudson, 2010, p. 16).

Thus, there exist scholars who support the idea that the digital divide is an important social and communication policy concern, and that it needs to be redressed. These scholars suggest that it carries economic and social implications that affect social inclusion and participation. Raneta Lawson Mack (2002), for instance, argues that the digital divide merits study because of the increased use of technology in daily activities that spill over into 
professional life. For example, employers increasingly require employees to be familiar with computers and communication technologies (p. xvii). Some scholars such as Kirk St. Amant (2011), Anas Tawileh (2011), and Rachael Schwartz (1996) argue that bridging the divide is imperative for economic growth and for effective internal operation of countries' markets and governments in an increasingly globalised world.

Thus, there is a financial aspect to the digital divide. As access to ICTs and communication services promote economic development, so too do economic developments promote ICT access. This is a cyclical problem within the Central America because annual levels of income have been historically low. As Table 1.1 shows, average annual income for most countries has never exceeded US $\$ 4,000$.

Table 1.1: Annual GDP per Capita (US Dollars)

\begin{tabular}{|l|r|r|r|r|r|r|}
\hline Country Name & $\mathbf{1 9 9 0}$ & $\mathbf{1 9 9 5}$ & $\mathbf{2 0 0 0}$ & $\mathbf{2 0 0 5}$ & $\mathbf{2 0 1 0}$ & $\mathbf{2 0 1 3}$ \\
\hline Costa Rica & $2,404.85$ & $3,370.23$ & $4,058.04$ & $4,621.36$ & $7,773.18$ & $10,184.6$ \\
\hline El Salvador & 898.35 & $1,652.83$ & $2,204.15$ & $2,814.93$ & $3,444.45$ & $3,826.08$ \\
\hline Guatemala & 860.5 & $1,468.06$ & $1,721.72$ & $2,146.18$ & $2,882.38$ & $3,477.89$ \\
\hline Honduras & 621.75 & 699.4 & $1,139.51$ & $1,401.97$ & $2,078.32$ & $2,290.78$ \\
\hline Nicaragua & 243.95 & 888.61 & $1,001.25$ & $1,158.99$ & $1,535.19$ & $1,851.1$ \\
\hline
\end{tabular}

Source: World Bank (2015) World Development Indicators

Low income levels affect the accessibility to ICTs and services across the countries. For instance, As Table 1.2 shows, prices for basic prepaid mobile phone in recent years have been affordable, but there is a difference between the prices of pre-paid and post-paid services. A prepaid 500MB mobile handset would cost Hondurans 16 percent of their annual income in 2013 (ITU, 2014). Moreover, broadband internet services are among the most expensive services in the region. For instance, as shown in Table 1.3, Nicaraguans needed spend on average 11.6 percent of their annual income for fixed-line broadband subscriptions in 2013. Guatemalans 
Table 1.2: Prepaid Mobile Phone Phone - Price of a One-Minute Local Call (off-peak, off-net) (Converted to USD)

\begin{tabular}{|l|rr|r|r|r|r|r|}
\hline Country Name & $\mathbf{2 0 0 8}$ & $\mathbf{2 0 0 9}$ & $\mathbf{2 0 1 0}$ & $\mathbf{2 0 1 1}$ & $\mathbf{2 0 1 2}$ & $\mathbf{2 0 1 3}$ \\
\hline Nicaragua & 0.32 & 0.3 & 0.2 & 0.34 & 0.37 & 0.43 \\
\hline Guatemala & 0.07 & 0.11 & 0.11 & 0.11 & 0.27 & 0.3 \\
\hline El Salvador & 0.3 & 0.15 & 0.15 & 0.14 & 0.17 & 0.14 \\
\hline Honduras & & 0.17 & 0.14 & 0.14 & 0.17 & N/A & 0.14 \\
\hline Costa Rica & & 0.04 & 0.05 & 0.05 & 0.05 & 0.06 & 0.06 \\
\hline
\end{tabular}

Source: World Bank (2015) World Development Indicators; ITU (2014) World Telecommunications Indicators database

Table 1.3: Fixed (wired)-broadband monthly subscription charge (converted to USD)/ Percentage of GDP Per Capital Spent

\begin{tabular}{|l|r|r|r|r|r|r|}
\hline Country & \multicolumn{1}{|l|}{$\mathbf{2 0 0 8}$} & $\mathbf{2 0 0 9}$ & $\mathbf{2 0 1 0}$ & $\mathbf{2 0 1 1}$ & $\mathbf{2 0 1 2}$ & \multicolumn{2}{|c|}{ 2013 } \\
\hline Nicaragua & $24.6 / 19.7 \%$ & $26.11 / 21.47 \%$ & $27.34 / 21.37$ & $16.29 / 11.66 \%$ & $17.95 / 12.12 \%$ & $17.95 / 11.63 \%$ \\
\hline Guatemala & $37.54 / 15 \%$ & $37.35 / 15.63 \%$ & $34.16 / 14.22 \%$ & $28.68 / 9.88 \%$ & $20.86 / 7.49 \%$ & $28.03 / 9.67 \%$ \\
\hline Honduras & N/A & N/A & $18.96 / 10.94 \%$ & $16.72 / 8.81 \%$ & $16.93 / 8.68 \%$ & $13.94 / 7.3 \%$ \\
\hline El Salvador & $20.34 / 7 \%$ & $20.34 / 7.3 \%$ & $24.86 / 8.66 \%$ & $15.82 / 5.13 \%$ & $20.34 / 6.45 \%$ & $15.81 / 4.95 \%$ \\
\hline Costa Rica & $21.1 / 3.84 \%$ & $22.98 / 4.31 \%$ & $14.42 / 2.22 \%$ & $13.7 / 1.88 \%$ & $14.94 / 1.9 \%$ & $14.79 / 1.74 \%$ \\
\hline
\end{tabular}

Source: World Bank (2015) World Development Indicators; ITU (2014) World Telecommunications Indicators database

Table 1.4: Monthly subscription for residential telephone service (converted to USD)/ Percentage of GDP Per Capita Spent

\begin{tabular}{|l|r|r|r|r|r|r|}
\hline Country & \multicolumn{1}{|l|}{1996} & $\mathbf{2 0 0 0}$ & $\mathbf{2 0 0 8}$ & $\mathbf{2 0 1 2}$ & \multicolumn{2}{l|}{$\mathbf{2 0 1 3}$} \\
\hline Nicaragua & $2.54 / 3.36 \%$ & $4.16 / 4.5 \%$ & $3.75 / 4.18 \%$ & $3.17 / 2.54 \%$ & $5.9 / 3.98 \%$ & $5.9 / 3.82 \%$ \\
\hline El Salvador & $6.05 / 4.1 \%$ & $7.13 / 3.88 \%$ & $8.34 / 3.83 \%$ & $9.44 / 3.25 \%$ & $6.89 / 2.18 \%$ & $6.89 / 2.16 \%$ \\
\hline Guatemala & $4 / 3.1 \%$ & $0 / 0$ & $5.84 / 3.61 \%$ & $5.84 / 2.44 \%$ & $5.84 / 2.09 \%$ & $5.84 / 2.01 \%$ \\
\hline Honduras & $0.9 / 1.53 \%$ & $1.37 / 1.44 \%$ & $2.04 / 1.88 \%$ & N/A & N/A & $3.83 / 2 \%$ \\
\hline Costa Rica & $2.05 / 0.7 \%$ & $2.8 / .82 \%$ & $3.45 / .97 \%$ & $3.9 / .71 \%$ & $3.9 / .49 \%$ & $3.9 / 0.45 \%$ \\
\hline
\end{tabular}

Source: World Bank (2015) World Development Indicators; ITU (2014) World Telecommunications Indicators database 
would need to spend almost 10 per cent of theirs. Prices for older technologies on the other hand, i.e. fixed-line telephone service, decreased in all countries since telecom reform in 1996, the only exception to this was Nicaragua.

The reality is that the issue of affordability in terms of communication services may increase the divide. Some scholars argue that the social and political implications brought on by this are significant. For example, Leopoldina Fortunati and Anna Maria Manganelli (2011), who conducted a 2009 study to analyze the relationship between cell phone use and social participation in five European countries. They attribute the likelihood of social participation-the "taking part to a greater or lesser degree in the activities of voluntary associations, groups of interest or religious groups" (p. 274) — to frequent mobile phone usage. Moreover, they found that users were more likely to maintain relationships with friends and close relatives as well as create new ones outside of their social groups (ibid.). Mossberger et al. (2008) explore the social and political implications of internet access. They do this by studying internet use and political participation using three national postelection surveys by the Pew Internet and American Life Project (p. 78). They found that "the [i]nternet promotes voting as well as political knowledge, interest, and discussion (p. 87). Yochai Benkler (2006) explores how ICT users worked together to defend democratic values on two occasions during the 2004 US presidential elections and again when Diebold electoral voting machines were found to have flaws (pp. 212-272).

Many have suggested that ensuring access to ICTs can be done through the promotion of universal service initiatives. These include, but are not limited to, universal service funds and conditions for licensing (GSMA, 2007). Universal service funds are "tariffs designed to generate revenue...that could be then directed to subsidizing expansion or rates for services" in areas of need (Hudson, 2010, p. 16). Funds can be generated either by government or through portions of 
revenues generated by those within the sector (ibid.). Additionally, conditions for licensing can be set to ensure that service providers serve population segments that may otherwise not receive any services. We can look at Brazil for one such example: in 2007, when issuing licenses for 3G mobile services, the government "imposed more expansive coverage obligations than the obligations previously imposed on the first mobile licensees" so that "areas of low demand...were included as coverage obligations along with the more populous licences" (GSMA, 2007).

Some suggest that the use of mobile technology will lead to proper execution of universal service policies. The Groupe Speciale Mobile Association, or GSMA (2007), a group that represents the interests of mobile operators around the world, for example, suggests that a majority of current universal service obligations are not attainable as they are oriented to be "fixed-line" friendly. Instead, the group argues that obligations should revolve around wireless needs as the majority of people in developing countries rely on wireless communication devices for services. Some scholars, such as Schwartz (1996) and Tawileh (2011) echo this sentiment, arguing that policies should be geared more towards wireless services and less to fixed-line communication services.

There are also some who are critical toward the rollout of universal service funds and policies. They argue that initiatives fall short of their goals because of inadequate policymaking. For example, Hudson (2010) argues that while universal service funds in Latin America have helped with the development and accessibility of countries' telecommunications facilities, they carry significant problems, two of which stand out. First, funds are at times not properly allocated, or in other words, as Ewan Sutherland (2012) argues, there is corruption and misallocation of funds. Second, many countries' universal service policies are guided by vague 
definitions and goals, which consequently are not met (Hudson, 2010). Alleman et al. (2010) similarly argue that definitions of universal service policies are too vague, and that policies are continuously pushed by politicians and business elites/providers despite not being effectively executed.

Some, such as Hilbert (2009) suggests that trying to bridge the digital divide in Latin America through universal service funds is not realistic. Hilbert suggests that a more effective approach would be to roll out policies that encourage universal access instead of service. Such approaches have seen some success in the past: Arturo Kunigami (2009) writes that universal access programs implemented in Central and South America between 1995 and 2005 have improved the accessibility of communication services through the creation of telecentres and new payphones. However, he also observes that "universal service funds showed some limitations, especially in more complex projects," citing slow disbursement of funds to support universal service, subpar infrastructure, mismanagement of telecentres, lack of fund flexibility, and regulation that has not kept up with new ICTs.

At the same time that there are scholars who argue that the digital divide should be addressed, the literature suggests that opposing these perspectives are authors who see little need to address the "digital divide". Furthermore, they are also skeptical towards universal service initiatives. For example, Benjamin Compaine (2001) suggests that the divide is nothing more than a mere "gap" between early and late adopters of technology. For Compaine, the digital divide is an issue of whether access to ICTs should take precedence over other "essential" services, such as access to health care. He suggests that that the democratizing potential of ICTs has been overhyped, and that ICTs are more likely to be used for entertainment purposes rather than for political activism (p. 115). Instead of arguing over the definition of the divide, 
Compaine argues that we should question which services a society should prioritize as "necessities", and whether we should classify ICTs as such (p. 116). Moreover, he argues that enforcing legislation to close the divide may actually halt ICT development because technologies evolve faster than the rollout of universal adoption (p. 114).

Additionally, Compaine and Weinraub (2001) explore whether or not there is any historical justification for expanding the notion of universal phone services to newer information services. They argue that the term is not appropriate in the present day by suggesting that what matters is not access to ICTs per se, but the ability to be connected through information resources, such as through "[posting] the daily newspaper in a public place, either in the town centre or the public library" (p. 171). They suggest that there are four hurdles to implementing a solid universal service: economics (someone needs to pay for it), bad timing (it can take decades before it's clear which services are actually "necessary" for living), priority-setting (the question of whether the digital divide should take precedence over other services, like health care), and necessity (inexpensive ways to access communication services already exist) (pp. 166-167).

For the purpose of this thesis, I approach the digital divide as an issue concerning access. I do this specifically by stressing the importance of infrastructures because, simply put, without infrastructures, there can be no services. This is to follow Jeffery James's (2003) approach to the divide, which encompasses access to telephone and internet services (pp. 112-117). The available literature on El Salvador's telecom sector, as well as the rest of Central America's, is limited but informative. For historical information on the Central American telecom sectors, I draw on scholars who have written on the histories of telecommunication sectors in each country, such as Bull (2005), and Raventos (1998), as well as historical information provided by the regulatory bodies themselves. 
Other scholars have written on the case of El Salvador's telecommunication sector specifically. For example, Lemus and Villatoro Canales (2009) conducted a study of the digital divide in the country by using ITU and World Bank data to explore trends with respect to telecommunication services rollout. They also used data from El Salvador's statistical agency, the General-Directorate for Statistic and Censuses, or DIGESTYC, to observe social conditions in the country, such as level of education, and where these are determinants of ICT access and use. They argue that the country's telecom regulator, SIGET, has not adequately addressed the digital divide as there remains a disparity between those who have access to services and those who do not. For Lemus and Villatoro Canales, the divide is associated with social class as those who had more education and of higher income were more likely to have access to telecom services.

Similarly, Pedro Argumedo (2007) conducted a study of market competition and regulation in El Salvador for the United Nations Economic Commission for Latin America and the Caribbean (CEPAL). In his analysis, he outlines the reasons for privatization within the country and the evolution of pricing scheme for fixed and mobile phone, using data spanning from 1993 to 2005. He suggests that while the quality of competition of El Salvador's telecommunication sector has improved since 1993 and ranks high among those in the region, there remains issues that need addressing, including the overall regulatory framework of the country, as it has not adequately addressed issues regarding market competition (p. 62). At the time of his study, less than half of all homes had access to telecommunication services. There was also a lack of study or analysis by SIGET to find solutions to these problems (p. 11).

Finally, Brunilda Funes (2002) explores the role of international organizations in the development of telecom services in Central America. She suggests that through the privatization 
process, "the reality is that the full benefits of these technologies do not reach yet to the majority of people living in Central America" (p. 7). It is my intention to add to this work by comparing SIGET with the rest of Central America's regulators.

The literature reveals that most Central American telecom sectors were privatized within a relatively short time span in the 1990s and that most countries had operated under military dictatorships. El Salvador was no different. After having gone through a civil war throughout the 1980s and early 1990s, the literature illustrates that the country looked to bolster its economy and national infrastructures, with one of the latter being its telecommunication infrastructure.

Government operation of telecommunication services in the country is rooted in the 1800s, but were restructured under an "autonomous institution" in 1963 with the Administración Nacional de Telecomunicaciones (ANTEL) (Argumedo, 2007, p. 14). In 1975, a law was enacted that established ANTEL as the sole controller of radio spectrum and declared that all technologies under ANTEL's control to be "used in the public's interest". ANTEL maintained control of all telecommunication services until 1996 after the civil war (Argumedo, 2007, p. 7; SIGET, 2013). The civil war incurred heavy damages to the country's telecommunication infrastructure as communication lines and towers were considered high-value targets and often destroyed (SIGET, 2013). In an attempt to generate revenues and repair its infrastructure, the legislative assembly approved Decree no. 807, which paved the way for the creation of SIGET (Argumendo, 2007, p. 16). In 1998, SIGET was established as the country's telecommunication regulator. During this time, the federal government auctioned off both the country's wireless services, CTE, and fixed-line services, Intel S.A. Both services were sold to foreign investors (ibid.). 
In short, El Salvador's case for privatization was based on the assumption that it would generate quick revenues and wide service distribution. But is this always the case? Scholars such as Jorge Hitsherich and Juan Roldan Perea (2007), William Melody (1995), Eugenio Rivera (2008), Bjorn Wellenius (2000), and Benedicte Bull (2005) have differing opinions on the effectiveness of markets to address issues surrounding the digital divide, in addition to the degree that regulatory bodies should interfere with their operations. Analysts have suggested that where there is limited access to telecommunication services, as is the case most notably in developing countries (Melody, 1995, pp. 249-250), there is a strong role for governments to play. However, this role is mostly one of a policymaker and regulator, rather than as a telecommunication service provider.

This role would be put to the test. In the 1980s and 1990s, many developing countries privatized their telecommunication companies for two main reasons. One was to stimulate economic growth (Bull, 2005, p. 21; Petrazzini, 1996, p. 31; Mody and Tsui, 1995, p. 179; Mosco, 2006, p. 177). Another was to increase the competition within the sector by limiting government control of telecommunication markets (Petrazzini, 1996, p.42; Bull, 2005, p. 19). However, some scholars argue that privatization has not adequately addressed the latter assumption because of inadequate policymaking (Rivera, 2008, p. 93; Bauer, 1995; Wellenius, 2000; Casanueva-Reguart,2013); as such, the poorest segments of the population have been ignored when discussing the digital divide and universal service initiatives (Hitsherich and Roldan Perea, 2007). Moreover, there remains an existing power relation between government and private sector elites (Bull, 2005, p. 1). These factors may have actually widened the divide in developing countries instead of bridging it. 


\section{$1.2 \quad$ Research Methodology/Process}

The research method for this project is a comparative analysis of the five Central American countries: El Salvador, Nicaragua, Guatemala, Costa Rica, and Honduras. These countries were picked because of, first, as previously stated, their historical linkage. Second, I hope to contribute to underdeveloped body of research on the Central American digital divide and telecommunication policies, one that Funes (2002) and Bull (2005) have written on. While my thesis covers a time frame ranging from the mid-1800s to 2013 , the central focus of my

analysis (chapter 5) will cover the years spanning 1996 to 2013. This is the time period in which most Central American telecom sectors were privatised. As such, this will allow me to compare the success that regulators and states have had in addressing the digital divide before and after sectors have been privatized.

The history of telecommunication services is closely tied with politics. Therefore, along with scholars who have written on the telecommunication sectors themselves, this thesis will draw on scholars who have written on the political histories of Central American countries. These include scholars such as Phillip Williams and Knut Walter (1997), George Black (1984), and Monica Rankin (2012). Additionally, this thesis will explore the influential role that international financial institutions played in the development of services in the region by drawing on World Bank documents.

For historical information of the sectors, I draw on scholars who have studied the region's sectors such as Alejandra Herrera (1996), Pedro Raventos (1997), and Benedicte Bull (2005). Additionally, I also draw on scholars who have conducted studies of the sectors for CEPAL, such as Pedro Argumedo (2007), Carmen Urizar (2007), and Marlon Tabora (2007). For information on universal service policies, I draw on scholars who have studied Universal 
Services in the region such as Stern and Townsend (2007). Additionally, I draw on universal service policy documents and the ITU for data concerning fixed-line, wireless, and internet distribution in the region. I will analyze the uptake and distribution of these communication media to follow Jeffery James' (2003) recommendation that universal services should encompass telephone and internet access (pp. 112-117). These sources illustrate the historical development of telecom regulatory bodies as well as the relationship between the regulatory bodies with the state and the private sector. Scholarly sources were obtained through the Carleton library and, in some cases, such as with ITU data and universal service policies, through the agencies themselves.

However, there lie weaknesses and limitations in these sources. Because Central America's early history is one filled with military dictatorships, obtaining reliable, consistent empirical data on the region's early telecommunication networks is difficult. There is one source in particular from which this thesis could have benefitted from, AT\&T's Telephone Statistics of the World ${ }^{l}$, as it is known as reliable source for telecom data in the early twentieth century. However, their archives are located in New Jersey and San Antonio and are only accessible inperson, by appointment. Travelling to either city was not possible for this thesis because of time and financial constraints. Any subsequent research relating to early Central American telecommunication history should consider this source. Early ITU data was also consulted but these focused more on developed and larger countries of the early $20^{\text {th }}$ Century.

Additionally, sources tend to focus on the digital divide in either 1) the South American countries of Latin America (such as Chile and Argentina), or 2) the larger of the Latin American

${ }^{1}$ AT\&T released its first publication in 1910. It was later renamed The World's Telephones and published from 1912-1914, 1919-1940, and 1946-1992. 
countries (Mexico, Brazil). To find information on Central American telecom regulators specifically, I look to the regulators themselves as well as international institutions, like CEPAL, the ITU, and World Bank. I will be drawing from journals that have published works on the digital divide in Central America, including Telecommunications Policy, The Quarterly Review of Economics and Finance, Intermedia, Info, as well as edited collections from Rivera (2008), Hernan Galperin (2007), and Noam (1996).

I will use primary data sets from the International Telecommunication Union (ITU) and The World Bank data indicators. These organizations collect data from different telecom sectors around the world. The World Bank also provides data sources that are not strictly telecomrelated, such as GDP per capita and measurements for education level. This is important because as stated earlier in this proposal, there are scholars who have suggested that the digital divide transcends the issue of access to telecommunication services, and that there exist links to levels of education and income.

These data sets will help determine if other factors have played a role in the divide in the region, such as an income divide or an education divide. The ITU data sources I will rely on include various issues of "Measuring the Information society" (2009-2014) and "The World Telecommunication/ICT indicators" (2014a). Both publications include data on a country-bycountry basis for internet and telephone access. I will be analyzing data that include figures of wire line telephone access, wireless access, and internet access from 1990 until 2013. 


\subsection{Organizational Framework of the Thesis}

This introduction chapter has provided a literature review on the concepts of the digital divide and universal service policies. These concepts underpin the rest of my thesis, which is broken into four chapters, and a conclusion.

Chapter two will provide an overview of theoretical perspectives that are appropriate to this thesis, including the theory of the state. It will draw on scholars such as Vincent Mosco, J.P. Sinha, Johannes Bauer, Bjorn Wellenius, and Petros Iosifidis for this discussion and emphasize how these scholars and theories of the state help us to understand the two main policy approaches that have had the greatest impact on telecommunications development and universal service and digital divide policies in Central America: privatization and liberalization of services.

In Chapter 3, I explore the early history of telecommunication in Central America with a particular focus on El Salvador, a time spanning from 1841 to 1979, just as El Salvador fell into Civil War. Central America's early telecommunication history is comprised of state-owned networks, low level of access, and much like in its reform-era, international investments. Additionally, this chapter explores the region's early political history; in doing so, it illustrates how military dictatorships used telecommunication services to accomplish state goals while ignoring the social needs of their populations.

Chapter 4 follows this with an overview of the privatization, liberalization, and reformation processes of the countries' telecommunication sectors. This will also draw on scholars who have written about telecommunication reform in the area, but will focus on the time frame of 1979 to 2013 so that it covers the time period of when telecommunications privatization was in full-swing. It will explore the arguments that have suggested that telecom reform was 
needed in the area as well as arguments that are against this claim. It will also explore the significance of foreign investment into the telecom sector, particularly those made by multinational telecom conglomerates, such as Telefonica, America Movil, and Millicom.

I will follow this in chapter 5 by using empirical data drawn from the ITU and the World Bank, as well as Universal Service policies from each country to assess how each country has addressed access to fixed-line telephone services, wireless telephone services, and internet services from 1996 until 2013. I will discuss the trends in service distribution and what they suggest for the future. Additionally, I will use this chapter to compare El Salvador with the rest of the countries by analyzing what El Salvador has done similarly or differently from the rest of the Central America. It will also act as an evaluation to see if the country has adequately addressed the digital divide compared to other countries.

Chapter 6 will provide a conclusion which will draw the ideas and arguments presented in this thesis together. 


\section{The State and Markets: The Shaping of Telecom Policies}

A distinction is often made between economic and social regulation. Analytically, this is fuzzy at best, as any economic regulation has social implications and any social regulation economic consequences (Bauer, 2010, p. 154).

Johannes Bauer's quote above reminds us that, especially in the realm of telecoms and the internet, markets do not act independently of regulation, nor is regulation developed without a keen eye to the interests of the market and particular competitors within it. States, markets, technology and competing views of the public interest are intertwined and how they are settled is a matter of power and politics. As such, the study of telecommunication and the digital divide fall within the domain of political economy. Therefore, this chapter examines theories of the political economy of telecommunications, with a specific focus on regulation and public policy goals related to the digital divide.

Examination of the state helps us understand the power dynamics and forces behind the policies that shape the development of and access to telecommunications services. Some have approached the relationship between states and markets with skepticism, as if they could exist independently of one another in a "perfect world". Others see the state playing the role of the "honest broker" adjudicating between rival interest groups and their respective claims.

Vincent Mosco (1989) argues that markets and states are never completely independent of one another. Each needs the other to accomplish social and economic objectives. When put in the context of telecommunications, and in the context of the right to communicate (as suggested in Article 19 of the UN Declaration of Human Rights) (McIver et al., 2003), this dynamic strongly influences whether policies to enhance people's access to telephone and internet 
services will be adopted and, if they are, what form they will take. Indeed, the dynamic between markets and states is especially evident in relation to telecoms services for these reasons and because, as noted below, telecommunication markets are rarely competitive and are closely tied to the state in relation to matters of national security and law enforcement.

In this chapter, I discuss the development of telecommunications in Central America to illustrate the historically tight knit relationship between the state and telecommunications. I also discuss that, despite early ideas in the 1980s and 1990s suggested that liberalization and privatization would lead to the role of the state in telecommunications being replaced by markets and private companies, the state has never completely withdrawn from markets. Rather, it changed the manner in which it intervenes. At the same time the role of markets and private companies has expanded. I also draw on the works of various scholars who have examined the changing role of the state in telecoms in developing countries within the context of privatization and liberalization over the last three decades (Bauer, 1995, 2010; Melody, 1995; Petrazzini, 1993; Sinha, 1995), as well as those who have offered general theories of telecommunications regulation, the role of the state, and markets. In terms of the latter, I emphasize three theoretical perspectives drawn from a broadly political economic approach — the pluralist, managerial and the class analysis perspective-drawn from Vincent Mosco's work (1988) to indicate how scholars have thought about and explained the roles that states play in addressing telecommunications and internet related issues.

\subsection{The Political Economy of Telecommunication: Competing Theoretical Approaches}

Regulation emphasizes that markets are important but also imperfect. Desirable goals and values that need to be pursued will not likely be satisfactorily obtained through markets alone. States use regulation to address social claims "by taking into account the views of those whose 
lack of market power would give them little voice in a pure market structure" (Mosco, 1988, p.

111). According to Mosco, regulation is not simply something that governments "do" to markets. Instead, regulation comes in multiple forms and can arise not solely from the role of the state in markets but also from marketplace competition and from experts. As he observes, private competition is a form of governance as well, one in which social claims are addressed primarily by the market (ibid.). Although a considerable amount of decision-making power is given to those within the market under the norm of private competition, the market itself "is not a selfcreating and self-sustaining mechanism" (ibid.). As such, two questions need to be kept in mind: who creates the market, and who benefits and suffers from whatever arrangements are adopted? (ibid.)

Expertise constitutes yet another, third form of regulation, one that is often operationalized through either expert boards or within state-created regulatory arenas (ibid.). Unlike regulation and private competition, expert boards are comprised of "groups of people whose right to governance is based on socially defined expertise" (ibid.). Expertise as a form of regulation is based on the idea that complex issues require specialized and independent knowledge that is not widely held by citizens at large. It is often in short-supply within specific markets because experts are often hired to represent the interest of competing companies. Thus, the question is how to organize experts in a way that they can function independently of such vested interests and that helps to reduce the "demand overload" of competing social claims raised by various interest groups that markets are ill-suited to handle. Expert boards can exist at different levels of the government, and this form of governance has been praised for its efficiency in dealing with social claims (ibid.). 
The fourth form of governance, corporatism, gives authority to "individuals who represent specific components of the economic division of labor [sic], particularly different sectors of business" (p. 112). Corporatism represents social claims in economic terms, and may also manage them more efficiently because "it vests authority directly in a body that reflects what the state defines as legitimate" (ibid.). Unlike other organizations or forms of governance which are governed by constitutional powers, a corporatist arrangement of power is rarely defined. This allows for "organized formlessness," or "the informal contact and extralegal activities that enable decision-makers to deal rapidly with changing conditions without attracting the publicity that comes with formal governmental action" (ibid.).

Understanding the balance between these various mechanisms for raising and settling social claims depends on the theoretical perspective that one adopts. Mosco identifies three such perspectives: the pluralist, managerial, and class-based, Marxist analysis. The pluralist approach sees the state as "one among numerous organizations... around which sets of interest coalitions focus their attention to meet their needs" (pp. 113-114). From this view, power is situational and operates under specific circumstances in relation to specific issues rather than being systemic and governed by overarching interests or values (p. 113). In addition, from the pluralist view, the politics of telecommunications and internet policy are bounded and delimited by a legal and organizational structure, and backstopped by the widespread acceptance of common values (p. 114). The state acts as an overseer of a market and society in general. There is no single, dominant voice on any specific issues or across issues, but rather competing interests and priorities that shift over time and across policy issue domains. The state does not intervene to pursue its own goals or to unilaterally impose solutions. Instead, it relies extensively on competition within markets, experts and rival social or interest groups who engage in a battle 
of ideas in a bid to convince the state that their "political clout is substantial and that [they conform] to the dominant value preference of the day better than [other] competitors" (ibid.). Pluralists see deregulation and privatization as consequences of shifting values and changes in technology (ibid.).

In the managerial perspective, the driving force behind the politics of regulation is not competing interest groups but rather "the need to manage the growing complexity brought about by technological change and the division of labor [sic]" that results in deregulation (p. 116). From this view, changes in communications technologies have blurred the lines between previously separate sectors of the communications industries - telecommunication, broadcasting, print and computing - upon which markets, regulatory regimes and legal frameworks had been built in the past. This has made it harder to distinguish what is regulable and what is not, and under which legal umbrella governments should act when they must. For example, Mosco writes that the regulation of AT\&T and the non-regulation of IBM in the US depended on the nature of each company's technology. AT\&T provided telephones (regulated) while IBM provided computers (non-regulated) (ibid.). The introduction of microelectronics-like microprocessors found in cell phones — and the entrance of outside players into telecommunications ("computer firms enter telecommunications and vice versa,") (ibid.) have made it difficult to maintain the "functional distinction" between technologies, further adding to the complexity of regulation (ibid.). Indeed, as the FCC in the US and the CRTC in Canada have shown, "it is difficult, if not impossible" to categorize these new technologies and services under old regulatory categories (ibid.). With no formal regulatory structure, those with more market power are able to resist challenges put forth by weaker players (pp. 116-117). The long-term reliance on the deregulated market to manage itself becomes problematic. While it may help solve short-term problems, the 
end result could lead to a variety of unwanted problems, including concentration of power (ibid.). Seen from this view, regulation is a technical problem in search of a technical solution, one that can be provided best by experts with highly specialized knowledge of the technologies, markets and law rather than by competing groups who have their own interests. The managerial approach also has the benefit of reducing political pressure and the number and range of claims on the state and regulatory and policy process. This is because whatever claims are made are funnelled through the channels of expertise rather than society at large.

In the class analysis perspective, regulation is neither situational nor a function of either experts or rival interest groups, but structural and systemic (p. 117). The class perspective takes two forms. Under the first, the state is seen as the "vehicle for maintaining class power without appearing to do so" and operates by "mobilizing and reproducing active consent of nondominant classes through moral, political, and ideological means" (p. 118). In other words, the state is the tool of particular capitalists, for example, large telecommunications firms. Under this view, the state represents particular class interests and helps to control and diffuse class antagonisms before they turn into outright conflicts (ibid.). One way it does this is by presenting itself as the public embodiment "of the people as nation" by denying the existence of class conflict (pp. 118119). In a second version of Marxist theories of the state, the state is not the tool of individual capitalists but rather functions as the "ideal collective capitalist" promoting the general interest of capitalism as a whole and promoting conditions necessary for the continued expansion of capital accumulation. Mosco argues that it fulfills this role by

providing and maintaining a productive infrastructure, creating and enforcing a legal order that makes markets and commodity exchange possible, regulating conflicts between capital and labor [sic], and promoting the total national capital in world markets (ibid.). 
Mosco (2006) discusses how these goals are pursued through four broader types of state intervention and market regulation: commercialization, where public service standards and other related standards are replaced by market regulation; liberalization, where the state regulates to expand the number of participants in the market; privatization, where the state "literally sells off a state enterprise" such as a telecommunication provider; and internationalization, where governments create regional or global organizations for their benefit (pp. 176-178). In each case, the state plays a fundamental role in expanding the market and, thus, the terrain of capital accumulation, while refraining from directly entering markets and, thereby, remaining dependent on revenue surpluses generated by private businesses. In other words, the state is the instrument of capital and is subordinate to it. As the following section will show, states and markets cannot operate by themselves to carry out initiatives, and importantly, states must rely on markets to carry out public policy goals, such as addressing the digital divide.

\subsection{Reasons to Regulate Telecommunication Markets}

Telecommunication markets seldom meet the vision of being truly competitive, but instead are often monopolistic or oligopolistic in nature. As Johannes Bauer (1995) writes, this is a problem because monopolies and oligopolies "do not meet the conditions of productive or allocative efficiency" (p. 269). In other words, they tend to lack innovation and the drive to bring about widespread access to services at reasonable prices. Drawing on the Austrian political economist Joseph Schumpeter, Bauer argues that a telecommunications market should have no less than four players to sustain "healthy competition", otherwise strong incentives for "open or tacit collusion" exist (p. 269).

Privatization processes that swept across Central and South America during the late 1980s and mid-1990s resulted in the widespread investment by foreign telecom providers 
(Petrazzini, 1993, p. 54). It also led to market monopolization and oligopolization within the region. In terms of providing services, privatization has succeeded to varying degrees; for instance, it has factored into the popularity of mobile phone use within the region, but has not been able to drastically increase home internet access (ITU, 2014b, pp. 242-243).

As Wellenius (2000) and Casanueva-Reguart (2013) state, governments rushed to privatise telecom sectors under the logic that privatization would lead to better services and wider access. While privatization and liberalization were promoted at the outset in Latin America as essentially substituting markets for the role of the state altogether, reality has played out differently. Instead, it has become increasingly clear to intelligent observers that without an adequate regulatory framework, privatization and liberalization on their own seldom deliver the benefits their advocates have claimed. As a result, there has been an increasing interest in the development of adequate regulation to ensure that, first, telecoms markets develop in ways that maximize the possibility of competition while also, second, recognizing that certain goals, such as universal service, will not be met by the market alone. Moreover, Johannes Bauer (2010) observes that the role of the state needs to be reconsidered in the post 2008-financial crisis world as "there is renewed acknowledgement that under certain conditions the state may be the appropriate organization to pursue public policy" (p. 162).

Telecommunications regulation has developed differently in different countries and regions of the world. Bauer argues that the development of telecommunications regulation has been an evolutionary process comprised of three stages: “1) monopoly regulation; 2) transition from monopoly to a more open market structure; and 3) regulatory intervention in unevenly competitive markets" (Bauer, 2010, p. 154). This model is derived from the histories of US and 
European regulation; in the US, the transition from the second phase to the third took almost fifty years, while in Europe, it took just over twenty (p. 155).

Throughout the $20^{\text {th }}$ century, network operators were thought to be natural monopolies, but recent times have revealed that monopolies at the network level do not necessarily mean monopolies of resource or service markets. Canadian and American telecommunications were "historically dominated by investor-owned, regulated service providers" (p. 152). Canada nationalized its overseas public-message telegraph services after World War II into the Canadian Overseas Telecommunications Corporation (eventually becoming Teleglobe) (ibid.; Harvey, 2003, p. 41). Most of the crown corporations created after the Second World War, however, were subsequently privatized in the late 1980s and early 1990s (Bauer, 2010, p. 152). In the US, the state briefly nationalized its telephone system in 1918, but this has mostly been seen as a monumental failure. Novertheless, the US has continued to support telecommunications by designing networks, such as ARPANET, the predecessor to the World Wide Web (ibid.). Bauer writes that, more recently, states have worked with municipal governments to establish wireless networks. This can be interpreted as a renewed "renaissance" of the state due to the "disappointment of overly optimistic expectations" of competitive markets (p. 153).

For most of the twentieth century (up until the 1990s), almost all EU-15 countries operated state-owned telecommunication systems (the exceptions were Italy and Spain) (p. 150). Unlike in North America, prior to the 1980s, European countries did not have separate regulatory agencies such as the FCC in the US or the CRTC in Canada. Nonetheless, they regulated telecommunications either through the ministerial level under which the state-owned telecommunications companies operated, or directly via the Post Telegraph and Telephone authorities, as such telecommunications providers were known. The result, however, was 
simultaneously bureaucratic lethargy, politicization and a lack of competition. National fragmentation was another outcome and one that impeded attempts to integrate the European market. This eventually resulted in the European Council and European Parliament taking steps "to harmonize national policies, to liberalize national and trans-European markets and to introduce transparent regulation" in the 1980s (ibid.). European states maintained ownership after these initiatives were introduced until the 1990s.

Petros Iosifidis (2011) argues that telecommunications have been conceptualized as public goods and thus regulated as such and in the "public's interest". While there is no standard definition of the public interest, regulatory efforts were legitimated on the grounds that they were essential to ensuring that telecommunication was available and affordable (p. 45). In other words, the public interest stipulated that services were available to people and that they were affordable. Drawing on Robert Horwitz, Iosifides also argues that certain infrastructure industries have historically been thought to have served the "public's interest" more than others. "Infrastructures industries" are important because they underpin the economy, as well as law enforcement, access to other public services, national security, government functions, and society in general. Infrastructure industries include "transportation, telecommunications, energy utilities, and systems of currency exchange" (p. 46). Telecommunications infrastructure has also been regulated through "common carrier" laws, laws which oblige carriers to allow "nondiscriminatory... access to its service at reasonable prices" (ibid.). Lastly, building infrastructure is expensive. The state has been perceived as one of the only entities capable of gathering the necessary capital for the "high level of fixed costs" required for building and maintaining telecommunications networks. This is important for providing services to citizens (J.P. Singh, 1999, p. 35). Like other major infrastructure projects, they have also been "seen as prestigious 
enough for direct state intervention" (ibid.). In other words, the public interest has also been conveniently linked to political considerations.

One way in which the state promotes communication as a public service initiative is through the promotion of universal service initiatives. Communication, including information access, sharing, and dissemination, is important for fostering socioeconomic development. Heather Hudson (1997) argues that to foster socioeconomic development, states must ensure that telecommunication services are accessible to its entire population (p. 80). Since providers in a competitive market have little economic incentive to serve everyone, the states intervene by the way of universal service or access initiatives. For developing countries, this means achieving universal access to basic communication services (i.e. telephones), universal service reliability, universal access to emergency services, and adequate pricing schemes (pp. 81-82). Policymakers support universality by ensuring that, first, the availability of the widest range of services exists; second, that there is no major price disparity among services; third, that connectivity is guaranteed among citizens; and fourth, that policies are flexible enough to be applied to new technologies (pp. 82- 83). Universal services are one way in which the state serves the public interest regarding communication services.

Latin American telecommunication services have not been nearly as developed as those of North America and Europe. This has contributed to the region's digital divide. However, the digital divide has also persisted because it is a microcosm of a larger issue within Latin America: the income divide. Indeed, as Evridiki Tsounta and Anayochukwu Osueke (2014) note, the richest households in Latin America earn twenty-five times more than the poorest ones (p. 11). 
This income disparity affects household expenditure on ICTs. Hilbert (2011) argues that "affordability is the key attribute of interest to track and bridge the digital divide" (p. 724); while wealthy citizens are able to spend income on ICT services, most Latin Americans lack access to services because they cannot afford them (p. 761). Indeed, Table 1.1 in the introduction chapter and Table 2.1 below, which shows compares the GINI coefficient ${ }^{2}$ of this thesis' five countries of study, illustrate this. Income inequality persists at very high levels even in 2013 . None of the countries can be classified as close to "equal" by any means.

Table 2.1: GINI Coefficient by Country since 1990

\begin{tabular}{|c|c|c|c|c|c|c|}
\hline Country Name & 1990 & 1995 & 2000 & 2005 & 2010 & 2013 \\
\hline Honduras & .57 & .55 & $\mathrm{~N} / \mathrm{A}$ & .59 & .53 & .57 \\
\hline Guatemala & $\mathrm{N} / \mathrm{A}$ & $\mathrm{N} / \mathrm{A}$ & .54 & $\mathrm{~N} / \mathrm{A}$ & $\mathrm{N} / \mathrm{A}$ & .55 \\
\hline Costa Rica & .45 & .45 & .47 & .47 & .48 & .50 \\
\hline El Salvador & $\mathrm{N} / \mathrm{A}$ & .49 & .52 & .47 & .44 & .48 \\
\hline Nicaragua & $\mathrm{N} / \mathrm{A}$ & $\mathrm{N} / \mathrm{A}$ & N/A & .40 & $\mathrm{~N} / \mathrm{A}$ & .40 \\
\hline
\end{tabular}

Source: UNDP (2013); World Bank (2015) World Development Indicators

This is despite the fact that Latin American states were "pioneers in the implementation of universal access programs" (Mariscal and Galperin, 2007, p. 8). As Gover Barja and BjornSoren Gigler (2007) write, because Latin America is "a region with high levels of social and economic inequalities and low levels of economic and human development" (p. 15), policies aimed at promoting telecom markets should work in conjunction with "pro-poor policies", policies aimed at improving social conditions for the poor and combatting social inequality. However, even if the digital divide presents an important issue for countries, it may not be a priority issue for governments, certain powerful social groups, or telecommunications

\footnotetext{
2 The GINI coefficient, which measures the level of income distribution of a country. A value of 0 represents "absolute equality". A value of 100 represents "absolute inequality” (World Bank, 2013).
} 
companies. Other social or political issues (such as health care or education) might also be given priority over ICT access (p. 19). Nevertheless, Barja and Gigler argue that access to ICTs plays a role in the

essential conditions for [social] development, as they affect every dimension of life. Likewise, [the digital divide] may only be one dimension of poverty, but [it] affects all other dimensions. For that reason its effective reduction is interdependent on the other dimensions (p. 16).

For the most part, the countries of this study have addressed the income divide with limited success. Barcena (2011) notes that household income has remained "heavily skewed" since 2002, as although countries have established policies to tackle the income divide, "the average per capita income of households in the upper 10 percent is about 17 times that of the poorest 40 percent, a slight improvement over 2002, when it was 20 times higher” (p. 20). In addressing the digital divide, most countries of this study have adopted universal service policies (at the time of writing, the only country to not is Honduras) (Kunigami, 2009; ITU, 2014). As noted above, while mobile phone use has proliferated in the region, broadband remains accessible to only a minority of the population.

Telecommunications have been crucial to the development of Latin American countries. Bull (2005) argues that this is the case for three reasons. First, state-owned companies assisted in centralizing state power as they helped the state communicate with the "hinterlands" (p. 35). Second, telecommunication companies "formed part of the coercive apparatuses of many states," and have been linked to surveillance and institutions such as the military (ibid.). Third, stateowned companies acted as a source for employment and helped to establish telecommunication infrastructures in key political communities (ibid.). They also served a charismatic function, 
given that the "establishment of state-owned companies was closely tied to nationalism and antiimperialism" (ibid.). In terms of social justice, state ownership was usually justified by being a "more powerful method of redistributing income than more conventional methods of taxation and government expenditure in developing countries" (ibid.). Such conditions prevailed until the late-1980s. However, while the tide has begun to turn in favour of privatization, competition, and increased foreign investment since then, J.P. Singh (1999) writes that in developing countries, "service enhancement, liberalization, and privatization [have been] piecemeal, slow, and capricious" (p. 37).

For Nikhil Sinha (1995), market reform in developing states is part of a larger picture of regulatory reform. Moreover, reflecting the historical lessons above, there is no universal, "blueprint", or institutional framework that will work for every market (p. 290). Rather, the effectiveness of regulation relies on, first, "the reform of the telecommunications sectors as a whole and the development of sector policies" and the "relationship between political institutions and the dominant political ideology" (ibid.). Second, rules and laws that structure the sector must be able to provide stability to the reform process. Third, "safeguarding institutions like the judiciary and, most importantly, the regulatory agencies and instruments developed to oversee and enforce the reform process" are essential (ibid.). These "safeguarding" institutions are important, as Melody (1995) argues, because privatization alone does not achieve policy goals. Privatization "must be carefully assessed in relation to other changes, particularly to government structure and market structure" (p. 259) to meet policy objectives. The keys to reform rely on "a clear separation of operational management, regulatory and policymaking functions" (ibid.).

Overall, competition and greater reliance on the market is premised on the idea that such an approach will help to achieve "up-to-date production and service delivery at reasonable 
prices" while protecting consumers and the public interest (p. 255). Competition is seen as a "vehicle to promote efficiency and facilitate the extension of universal service in some circumstances" (Bauer, 1995, p. 258). Arguments for the turn to markets and competition are also the strongest when public ownership fails (Bauer, p. 258). Some also argue that this renders the role of public ownership and government regulation obsolete.

After an early period of what might be called market fundamentalism, the reform of telecommunications came to be seen as a three part process of privatization, liberalization, and regulation. Ben Petrazzini (1993) writes that privatization became a global pattern in the 1980s, with the liberalization of telecom services following thereafter (p. 51). Furthermore, he argues that the timing of privatization affects liberalization: when competition precedes privatization, opposition to privatization is weak, "coming mainly from managers and employees of the national carrier" (p. 51). Because the state retains ownership of services, "the success of liberalization is tied to the political strength of the administration and its ability to overcome resistance within the state in order to enforce policy" (pp. 51-52). On the other hand, when privatization and liberalization happen at the same time, one of two outcomes occurs: "(1) domestic opposition to reform is co-opted, dismantled, or shielded at an early stage, or (2) the opposition succeeds in blocking and cancelling reform initiatives" (p. 52). Additionally, the introduction of private investors into the sector jeopardizes the success of liberalization because of conflicting interests: the state may strive for competition, but investors may be in search of establishing monopolies (ibid.). Even more importantly, Petrazzini argues, liberalization "is much more dependent on the condition and prospects of the country's domestic economy" than privatization is (ibid.). 
Developing privatized sectors also rely on foreign investment for sector development as developing states usually lack necessary capital (p. 53). Here, the state's bargaining power depends on certain factors, "such as the degree of the government's centralized control over reform negotiations and the number of firms competing for investment" (p. 54). A more politically and economically stable state is more likely to gain investor confidence (ibid.). Moreover, pressures from international institutions on the state, specifically, lending institutions such as the International Monetary Fund and the World Bank, affect policy-making. In advanced stages of privatization, these help shape the final regulatory framework and determine the openness of markets (Petrazzini, 1995, p. 58). Groups such as these provide states with the needed capital and expertise all the while pressing governments for reform, but also support privatization by working with local governments (p. 59). States with less political and economic stability are more likely to have policies and reforms influenced by these international actors (ibid.; Hills, 2007, pp. 149-174).

By the 1990s, commentators began to agree that the "idealized model of competitive markets" with respect to telecommunications is unlikely to fulfill policy goals (Bauer, 1995, p. 268; Melody, 1995; Petrazzini, 1995). Without regulation, Melody states, "a gentleman's" competition rather than real competition is what is most likely to develop (ibid.). As a result, good policies and adequate regulation need to be adopted to achieve objectives that would not otherwise be achieved. As Bauer (2010) argues, the state needs to assist the market when it faces "weaknesses and deficiencies of an unregulated market economy" (p. 159). It can assist in two ways. One is by attempting to "enhance the competitiveness of firms and sectors... to facilitate their adaptation to changing policies" and by pursuing goals through industrial policies (ibid.). He also argues that most European states have adopted the former approach through European- 
wide research and development programs and with individual nation-states initiating their own internet rollout programs. Second, the state can intervene through industrial policies, such as the US did by funding the development of ARPANET through the US Department of National Defence (ibid.).

Nikhil Sinha (1995) also agrees that without an adequate regulatory and policy framework, markets for telecommunications will not develop properly and the potential benefits of both markets and access to services will be lost. He argues that states have three choices when it comes to establishing an institutional framework for telecommunications: first, a free market, second, a market that is built on hierarchies (similar to bureaucracies), and third, a version that is a hybrid of markets and hierarchies (p. 289). Two sets of prevalent governance problems inevitably lead to the latter, he argues: first, once privatized, telecommunication services are often exploited by private monopolies in much the same way that they had been when they were government-owned; second, the close link between telecommunications and "national security interests and the protection of social goals like social equity" means that reliance solely on free markets is not realistic (p. 288). Regulation is unavoidable, and thus, it is the balance between markets and states that are at issue, not the simplistic dichotomy between markets versus states, as some imagine. In short, the state's role does not disappear with market competition but rather is transformed into that of the "enabling" state (see below), and, as Sinha (1995) states, "what matters is not [the state's] right to intervene but how it intervenes" (p. 293).

J.P. Singh (1999) argues that in developing countries, the state's manoeuvrability in this regard hinges on a "window of opportunity" to shape public policies before public interest groups are able to offer their input. However, these windows do not last very long and therefore mean that regulatory reforms must be put into place swiftly. Despite this, developing and 
dysfunctional states are able to exercise manoeuvrability by "[commanding] vast bureaucratic machineries" (p. 44).

How a state acts also depends on what kind of state it is. In this regard, Singh usefully distinguishes between three types of states: the catalytic state, the dysfunctional state, and the predatory state. The catalytic state plays a major role in shaping "future preferences...of powerful special interests... resulting in fast, comprehensive, and demand-led restructuring” ( $p$. 42). This kind of state is similar to what others, such as Iosifidis (2011) refers to as the "enabling state" (p. 115). In telecom regulation, its role is not eliminated, he argues, as it becomes a "key actor in media policy formulation and enforcement" (p. 117). Others, like Mody and Tsui (1995) have conceptualized the state in similar terms, arguing that its responsibility consists of "guiding, advising, encouraging, and subsidizing national capital towards ... profitable chains of production and distribution to cut across old political...boundaries" (p. 284). As an enabling state, the state facilitates the participation of market players.

The second type, found most commonly in developing countries, is the dysfunctional state, in which the state is either both a) inefficiently guided and dominated by a few interest groups, or b) is filled with "myriad of micro- and macro- level pressure" (p. 42). The state has "limited manoeuvrability," (ibid.) which leads to it being easily influenced by sectional and narrow interest groups.

Third, a state can be predatory, where it has little accountability or degree of manoeuvrability and "seldom meets user demands or takes any developmental initiatives" ( $p$. 43). The predator state is characterized by high levels of corruption and bribery. Ewan Sutherland (2012) writes that bribes can take many forms, ranging from "cash in bags and cases" 
to "shares in a corporation" (p. 6). This is often done to reduce revenues received by the state while increasing consumer prices, all the while ensuring "privatization of incumbent operators...issuing of licenses...regulation of prices and interconnection rates...importation of equipment...and approval for the siting of equipment" (ibid.). Moreover, "corruption on a grand scale requires money laundering to disguise the origins of its illegal sources, making the proceeds of crime appear legitimate" (p. 7). This is confirmed by the World Bank, which estimates that bribes in the world's poorest countries range from a total of US\$20-40 billion a year, "equivalent to the GDP of the 12 poorest countries" (p. 6). It is unsure how much is directly related to telecommunication sectors, but state officials who have been connected to bribery with telecom companies include state officials in Benin and former Prime Minister of Thailand, Thaksin Shinawatra (p. 7). Even with crackdowns, it is difficult to detect bribery when it happens (ibid.).

During the processes of liberalization or privatization in Latin America, states faced numerous challenges, one of which was remaining autonomous from non-state actors. This is important because it is widely accepted that regulatory bodies perform better when they are independent from the state or any "executive branch of government" (Bauer, 2010, p. 157). Autonomous regulators are the least susceptible to capture, either by the industry or governments (ibid.). Bauer argues that, ultimately, regulation falls on a spectrum ranging from regulation in the public interest to regulation that benefits special interest groups. In countries where there has been a growth in the number of stakeholders but no shielding for either Congress or the regulator from the pleadings of such stakeholders, the result has been gridlock and an inability to implement much needed policies and regulatory reforms (ibid.). 
The degree of the state's autonomy depends on the "historical genesis" of the state (Petrazzini, 1993 p. 46). This can unfold in two ways: first, the state can rise from "major social dislocations" (revolutions, political conflicts), which "tend to gain and maintain high degrees of insulation from societal demands" (ibid.). Second, the state can rise from "progressive transformation of the political and social system" in which they are more likely to give into societal pressures (ibid.). Central American states unfolded with the former approach. Autonomy also depends on the issue being politicized because the state may achieve greater autonomy on certain issues but not others. This is because "the vulnerability of certain areas to social pressures varies according to the kind of policies the government intends to implement and the actors involved" (p. 48). Telecommunications, for example, was traditionally an area where policymaking was left up to "bureaucrats and regulators," but this changed when "the mere consideration of privatization...moved telecom policy-making to the forefront of public concern" (ibid). Moreover, "political influence" over telecommunication policy in less developed countries has tended to be concentrated around groups comprised of business elites. This values their voices over others, thereby reinforcing inequality in society as a whole because business elite groups tend to be larger and wealthier. Singh (1999) writes that

historically, national telecommunications monopolies found it easy to favor [sic] these specialized groups "because state enterprises are ultimately controlled by politicians and government can more easily compensate public enterprises for the costs of accommodating these powerful interest groups" (p. 36).

In the context of liberalization and privatization, the interests of local and foreign business communities shifts from being not only interested in telecommunications users but also to those of being the new owners of recently privatized companies or of being new competitors 
entering liberalized markets. These business interests, quite rationally, will seek to minimize competition, essentially hoping to replace state-owned monopolies with privately-owned ones. Public interest groups, on the other hand, will pursue various social welfare goals and values, but businesses will typically oppose such matters on the grounds that they are not the proper purview of markets. Petrazzini (1993) argues that in the developing state, the struggle for autonomy is dictated by two economic functions: capital accumulation and redistribution (p. 45). Policies that focus on access, for instance, will likely be resisted from business groups who seek to maximize capital accumulation and profits. On the other hand, policies that promote capital accumulation over universal service goals will likely draw pressures from "politically powerful actors...who may have benefited from the redistributive functions of the welfare state" (p. 46). As a result, there will be significant pressure on the state to act in ways that will favour one set of claims over the other, and this will raise the problem of maintaining the state's autonomy amidst these competing pressures (ibid.).

Given these realities, several observers argue that "cohesive", and "centralized" states are necessary to successfully privatize telecommunications companies, to ensure that effective competition emerges, and to establish adequate policies and regulatory frameworks (Petrazzini, 1993, p. 49; Bull, 2005, pp. 31-32). Ultimately, a unified state where officials and bureaucrats see eye-to-eye on issues has a better chance of implementing reform policies than a fragmented one (Petrazzini, 1993, p. 51) However, privatization threatens state cohesion as it reduces state officials' economic and political power in addressing issues. When such cases arise, the effectiveness of the top leader(s) in managing competing groups determines the effectiveness of policy implementation (ibid.). This happens often, because privatization implies a "reduction of the bureaucratic control over the economy... which leads to disagreement and resistance among 
state constituents that, in turn, tend to be an important factor in the program's success or failure" (ibid.).

Similarly, Bull (2005) argues that a cohesive, centralized state is able to pursue its own interests because it is able to "penetrate the territory over which it is supposed to rule" and to implement policies to govern it (p. 32). These states eventually develop institutions "according to their own dynamic" without pressure from social forces. Those that are able to remain autonomous in economic and political issues are more likely to foster economic growth and development (ibid.). Centralized states have strong, autonomous state apparatuses that may set the agenda for ideas such as market privatization and liberalization (ibid.). On the other hand, states with less autonomy are more likely to be influenced by non-state elites when facing issues such as reform, and are thus prone to state capture, or even corruption (pp. 32-33).

Autonomy from external pressures also ensures that the state appears legitimate to the public. Drawing on Weberian concepts, Bull (2005) argues that state legitimacy is the foundation of "state dominance," which can take one of three forms: "legal-rational dominance' based on impersonal rule, 'traditional dominance' based on the belief in the sacred character of immemorial traditions, or 'charismatic dominance' based on the prestige of a person because of his extraordinary qualities" (p. 33). Bull argues that the state dominance commonly seen in Latin America is a mix of legal-rational dominance and "neo-patrimonialism," a kind of traditional dominance. Neo-patrimonialism "seeks to reduce the autonomy of...followers by generating ties of loyalty and dependence, commonly through complex patron-client linkages" (ibid.). It blurs the roles of public and private actors within the government (ibid.). In Latin America, this type of rule has traditions that are found in caudillismo, or "strong-man rule," which carries elements 
of "charismatic dominance" that portray the president (or head of state) as a charismatic, strong leader (ibid.).

However, Weberian concepts fail to distinguish between "the legitimacy of the state, the regimes governing it, or groups dominating it" because they imply that the ruler and other actors are one in the same (p. 34). Thus, Bull discusses two further concepts of legitimacy: democratic legitimacy and consequential forms of legitimacy. Democratic legitimacy refers to the state expressing the will of the population, and despite democratic values clashing with business ideals, it is "in general...the most legitimate regime form across Latin America" (ibid). Consequential forms of legitimacy refers to two kinds of legitimacy: "developmental legitimacy (legitimacy based on solving what are commonly viewed as problems), and distributional legitimacy (legitimacy based on counteracting...inequalities and elitism)" (ibid.). In short, both address the failure of democracy, specifically, when it "does not contribute to solving...problems, and [when] it does nothing to break the dominance of elites" (ibid.). As most Latin American states strive for democratic legitimacy, "what is... threatened is the legitimacy of political elites", not democracy (ibid.). At the same time, the state must also be mindful to appear legitimate to its public.

\subsection{Conclusion}

In this chapter, I have discussed how states and markets rely on each other to meet social and economic objectives. Moreover, by focusing on the relationship between Latin American telecommunication markets and the state, I have discussed how states rely on markets to carry out policies meant to address the digital divide, such as universal service initiatives. 
I have drawn on Mosco to discuss three political economic perspectives which explain how the state settles social claims: the pluralist, managerial, and class perspectives. For the most part, Central American states have adopted a class perspective. A few themes underscore this point: first, there is an economic-divide within the region which is a driving force behind the digital divide. Second, Central American states have acted as enablers of capitalism through liberalization and privatization processes of telecommunication markets, and in doing so, have missed opportunities to adopt adequate universal service policies. Third, Central American states have historically been ruled by oligarchical, caudillismo leaders that have privileged certain social groups while marginalizing others. Moreover, they have used infrastructures in their efforts to become centralized. In doing so, they have struggled to remain autonomous and have been prone to corruption.

In the following chapter, I will provide a historical account of how Central American states approached telecommunication services in the early years of the region in the region. As will be seen, the state has acted with a "class" mentality that has affected the rollout of telecom services, which at the same time has widened the digital divide. 


\section{Central American Telecommunication: The Early Days of Military Rule}

The need for a legitimate, strong government becomes obvious when public service needs arise, such as when infrastructures and networks require attention. For instance, Marcos Dias (2012) writes on Australia's Broadband Strategy and outlines its potential social benefits. The premise behind Australia's strategy is to bridge the division between those who have access to broadband services in the country and those who do not. The social benefits of the plan are numerous, as broadband access plays a role in obtaining "health, education, teleworking, economic opportunities, and access to government services". Key to bringing these services is the state's willingness to support infrastructural development to meet social needs when called upon. The early Salvadorian state, and for that matter, all Central American states, failed in this regard. Instead of developing telecommunication services to fulfill social objectives, it used services to fulfill military and economic objectives.

This chapter discusses the early history of telecommunication in Central America. The first part of the chapter focuses on El Salvador, where I map out the early history of the Salvadorian state and telecommunications from the mid-1800s to 1979. Second, I provide brief discussions of the early telecommunication history of the remaining four countries in Central America - Guatemala, Honduras, Nicaragua, and Costa Rica—from the beginning of their services to just before they were privatized. Three prominent themes emerge in the preprivatization history of telecommunications: first, repressive dictatorships played to the needs of social and economic elites. As the chapter shows, telecommunication in El Salvador and Central America has long been closely tied to the state through dictatorships and military functions and the consequences of such relationships have been significant and enduring. Second, Central 
American countries have relied heavily on foreign investments from private companies, such as the American-owned United Fruit Company (UFCO) and the World Bank to develop networks. Third, poor quality of services have plagued the region.

Central America's early political history is characterized by dictatorship; as Bull (2005) writes, Central American states "believed in a powerful central state that could intervene to promote authoritarian states...to produce openness, freedom and prosperity" (p. 39). While they may have been goals that states sought to meet, dictatorships seldom promoted openness, freedom, or prosperity. As I will discuss, more often than not, these authoritarian states were highly repressive and neglected to implement public policies that would benefit its citizens.

\subsection{El Salvador}

El Salvador's early history is characterized by political instability, repressive military dictatorships, and a reliance on foreign investments to carry out developmental projects. In the 1880 s, as it looked to adopt liberal economic policies, the country dealt with various internal conflicts between liberals and conservatives. The country's external conflicts were equally as destabilizing: between 1841 and 1890, El Salvador had fought with Guatemala five times, Honduras four times, and Nicaragua once. Additionally, it experienced thirteen military coups (White, 2009, p. 57). Given these events, early governments repeatedly made national security a top policy objective, and as such, passed eight laws between 1825 and 1911 which expanded and refined police powers and security structures (ibid.). In doing so, the state grew repressive and the military's power grew stronger. As White writes, "military legislation increasingly expanded, with 30 legal stipulations providing for a more professionalized military between 1839 and 1858 alone" (ibid.). 
El Salvador's liberal-dictator rule began with Francisco Duenas in 1871. Leaders like Duenas felt that economic development was crucial to state development, and as such, focused on building infrastructures that promoted trade (e.g. roads and railways) and attracting foreign investment (White, 2008, p. 69). Telecommunication lines were among these infrastructures, and early on, were developed with the help of foreign actors. On April 26, 1870, with equipment provided by the American company J. H Bunnel \& Co., the country's first telegraph line was built to connect the country's capital, San Salvador, with the Port of La Libertad, a shipping port along the country's pacific coast (Amill, 1947, p. 75). In subsequent years, telegraph lines became commonplace among larger cities, and by 1923, there were 235 telegraph offices across the country (ibid.). By 1879, all five Central American countries in this study-Guatemala, Honduras, Nicaragua, Costa Rica, and El Salvador — were connected by an overhead telegraph line that ran from San Juan del Sur in Mexico to San Jose in Costa Rica. The line was built by a foreign actor, the India Rubber, Gutta Percha and Telegraph Co. (a British company), and operated by the Central and South American Telegraph company, a company founded by the American "father of the cable business between the Americas", James Scrysmer (Huurdeman, 2003, pp. 128, 138; Telegraph Journal and Electric Review, 1882, p. 301).

Telephony soon followed. On November 5, 1887, a phone line connecting the nation's capital and the city of Santa Ana was opened to the general public. The line was considered essential to "the entrepreneurial spirit and progressive spirit" of the government, as well as an asset for "commerce and public use in general" (Diario Oficial Num. 259, 1887)—at 25 cents a minute, it was cheaper to use than the country's telegraph line (ibid.). By 1922, the service had grown to 238 telephone offices (Amill, 1947, p. 76). Telecommunication services would become 
a government monopoly operated by the Telecommunications Bureau of the Ministry of the Interior established in 1937 (p. 75; Lundell 1954, p. 11).

As telecommunication lines developed, so did the class divisions within the country. Because El Salvador was still in its "formative years", state functions tended to serve elite and military interests rather than the majority, peasant-class, population. This unequal balance between the state, elites, and the poor would often lead to violent clashes between the peasant class and elites, and between elites and other elites. Moreover, between 1841 and 1898, fiftyeight different political and military figures became head of state, either through coups or elections (White, 2008, p. 71). The final coup of 1898 held a "real and symbolic importance as a forecast of the coming change in the functioning of politics in El Salvador" as it marked the beginning of initiatives which aimed for state centralization (Ching, 2014, p. 173). The period from 1913 to 1926 was marked by initiatives towards this end with the creation of roads, railways, banks, and security forces to protect property and to enforce vagrancy laws (p. 174). Communication infrastructure was primarily used to promote these initiatives. Particularly at this time, the country had transformed itself into an agro-export based economy, and the state did whatever it could to take advantage of rising coffee prices on the world market. The state allocated "the developed infrastructures" of the country to assist in coffee production, including its communication infrastructure (Salazar, 1987, p. 27). As a result, the country experienced "unprecedented amounts of wealth... [which] gave the country both the means and the motivation to increase the size and powers of the state" (Ching, 2014, p. 174).

Dictatorships dominated the country's political and social landscape for much of the first half of the $20^{\text {th }}$ century. For instance, El Salvador's first radio station went on the air on March 1, 1926 under the call sign of AQM - an acronym of the president's name at the time, Alfonso 
Quinonez Molina (Benitez, 2014, p. 124). Dictatorship was briefly interrupted during a period of democracy from 1927 to 1931. This is because in August 1926, while Molina was serving his final presidential term allowed by the country's constitution, he sought to rewrite the constitution to allow him to serve an additional term. However, fearing that this would be frowned upon by the US (which the country depended on heavily for foreign investments), he turned to and supported the candidacy of his vice president and Minister of War, Pio Romero Bosque. An election was held in which Bosque ran unopposed, and he was subsequently named President of the Republic (Ching, 2014, p. 209).

However, Bosque surprised many military officials and elites through his intentions to rid the country of its clientelistic, dictator ways. Instead, Bosque looked to implement democratic reforms as he wanted to create a "genuine democracy" (ibid.). Such reforms included keeping the military in check by appointing and demoting officers of various positions (p. 233). While this was looked upon favourably by the US, it was met with concern and dissatisfaction among El Salvador's elites (p. 209). Near the end of his term, in 1931, a presidential election was called in which Arutro Araujo came out victorious. However, Araujo's presidency—and consequently, the democratic reforms introduced by Bosque — ended ten months after his election in December 1931. Araujo's vice president, General Maximaliano Hernandez Martinez, staged a military coup and overthrew Araujo. Martinez became the new President of the Republic and carried out the remainder of Araujo's presidency (a term lasting until 1935) and then went on to serve two additional terms, first from 1935 to 1939, and then from 1939 until he was forced from office in 1944 (p. 246). Although military dictatorship was nothing new to the country, Martinez's dictatorship was new in the sense that he was "a ranking officer in a professionalizing, centralizing army [that] was in charge of the government" (ibid.). Additionally, "several of his 
high-ranking counterparts held key offices" (ibid.). This meant that state politics and military affairs were now intertwined.

The military's grasp of the country grew throughout Martinez's dictatorship. It went as far as drafting a new constitution in 1939 which "gave the state an unprecedented role in controlling the economy, communication, and the media" and made for repressive living conditions (Salazar, 1987, p. 54). Article 56 of the constitution gave the state the exclusive rights to operate postal, telegraph, telephone, and radio services. Moreover, Article 106.12 dictated that the state was responsible for maintaining, improving, and expanding phone services (El Salvador Government, 1939). However, state ownership did little to improve telephone density within the country. As Table 3.1 shows, while El Salvador had more telephones than its neighbouring countries, it had far less than other North or South American countries.

Table 3.1: Estimated total number of Phones/Estimated phones per 100 people (1925)

\begin{tabular}{|l|l|}
\hline Country & Number of phones (1925) \\
\hline USA & $13000000-20000000 / 14.45$ \\
\hline Canada & $1143000 / 12.3$ \\
\hline Argentina & $100000-300000 /$ N.A \\
\hline Mexico & $50000-100000 / 0.5$ \\
\hline Uruguay & $10000-50000 /$ N.A \\
\hline El Salvador & $\mathbf{2 5 0 0 - 5 0 0 0 / 0 . 2 5}$ \\
\hline Honduras & $1000-2500 / 0.25$ \\
\hline Costa Rica & $1000-2500 / 1.6$ \\
\hline Guatemala & $1000-2500 / 0.1$ \\
\hline Nicaragua & N.A \\
\hline
\end{tabular}

Source: Huurdeman (2003, pp. 233-235) (based on data from Bell System Technical Journal and Archiv für Post und Telegraphie) Statscan (n. d.) Estimated population of Canada, 1605 to present; Mitchell (2007) International Historical Statistics, $6^{\text {th }}$ Edition.

\footnotetext{
${ }^{3}$ Because exact population statistics were difficult to find, "Telephones per 100 people" are estimates. This figure was calculated by taking the estimated number of phone lines and dividing it by the estimated total population. Some figures could not be estimated because of large gaps between years of available data.
} 
By the middle of the 1940s, the country's economy was slowing and faced massive amounts of external debt (Amill, 1947, p. 17). Exports had slowed during the Second World War and the government continuously spent on its military while neglecting other sectors (Salazar, 1987, p. 55). An outdated telecommunication system did not help its cause: by 1946, El Salvador's telegraph and telephone systems were old and a mix of old and new parts. By 1948, only 5,256 telephone lines were in use to service its two million people, amounting to virtually 0 phone lines per 100 people (Amill, 1947, p. 81). In comparison to other Latin American countries around this time, Uruguay had 60,398 lines for its 2.3 million people (0.02 lines per 100 people) while Argentina had 533,328 lines to serve its 16.1 million people ( 0.03 lines per 100 people) (ITU, 1949). The US had just over 43 million telephones for its population of under 151 million inhabitants (0.28 lines per 100 people) (Huurdeman, 2003, p. 233, US Census Bureau).

Moreover, the access issue was not exclusively a Salvadorian one but one prevalent across Central America. In 1955, the region had a far lower telephone density level than other South American and North American countries. This is illustrated in Table 3.2.

Table 3.2: Total Number of telephones/telephones per 100 people

\begin{tabular}{|l|l|}
\hline Country/Region & $\mathbf{1 9 5 5}$ \\
\hline USA & $52806000 / 30.89$ \\
\hline Canada & $3857000 / 24.51$ \\
\hline Argentina & $1080000 / 5.7$ \\
\hline Central America & $\mathbf{4 8 8 0 0 0 / 3 . 4 8}$ \\
\hline Mexico & $349000 / 1.06$ \\
\hline Uruguay & $109000 / 4.59$ \\
\hline
\end{tabular}

Source: Chapuis and Joel (2003, p. 279) (Data is based on AT\&T Telephone Statistics of the World); UN World Population Prospects (n. d.).

Additionally, and as an indicator of the under-development of the service and pent up social demand, 600,000 people had been put on a waiting list for telephone services in El 
Salvador (Huudeman, 2003, p. 557). The amount of people who were waiting for telephone service was "larger than the number of subscribers served", causing "wait times of up to 16 years" (ibid.). The state looked for ways to dig itself out, and thus, looked to restructuring its telecommunication system.

\subsubsection{The Birth of ANTEL}

By 1950, El Salvador, along with the rest of Central America, had entered "a new historical economic period" where it looked to "loosen its dependence on fluctuating prices of international agro-exporters" (Salazar, 1987, p. 61). At the same time, El Salvador, along with the other five Central American countries, were in need of updated telephone systems as their current systems were antiquated and severely lacking connectivity. Indeed, a report from the World Bank in 1954 wrote on the country's telecommunication system, saying that "most of the equipment is extremely old, and in some cases, antiquated and useless" (World Bank, 1954, pp. 15-16).

After years of financing its military and neglecting its infrastructures, Post-World War Two El Salvador saw telephony as imperative to the country's economic and social development initiatives; as a World Bank (1972) report states, "for the development of national resources and to provide a rapid, reliable means of exchanging information between the producers, ports and San Salvador...adequate telecommunication services are essential” (p. 2). Thus, the lack of service distribution and outdated technology caused the government great concern. The Telecommunications Bureau of the Ministry of Interior, however, could not expand or modernize the national telephone network because it lacked the staff and the substantial amount of capital needed for the task (World Bank, 1963, p. 2). 
President Julio Adalberto Carballo decided to address this matter. Under his presidency, the state restructured its national telecommunication system. In 1963, Decree no. 370, The Law of National Administration of Telecommunication Services, was passed, thereby creating the National Administration of Telecommunication Services, or ANTEL, an autonomous institution to oversee all "telecommunication services", including "telephone networks, telegraph, radiotelephones, radiotelegraph, etc.; as well as their management, installations, and services" (Decree no. 370, 1962, Chapter 1.2). ANTEL was put in charge of overseeing and managing telephone facilities, subterranean communication cables, above-ground telephone wires, telegraph wires, radio transmitters, radio relays, teleprinters, and "whatever innovation that may contribute to telecommunication services". The law stated that ANTEL was not only a part of the country's economic development plan, but also a means to promote public service initiatives.

While ANTEL was in charge of overseeing telecommunication services, in cases where it could not provide suitable long distance services, it allowed "private users to obtain licenses from the government on an annual basis to operate point-to-point HF radio systems" (World Bank, 1972, p. 2). Access to these services was divided as services were provided via a microwave system in larger, urban cities while smaller, "less important towns" were connected via “open-wire lines with carrier systems" (p. 3).

There were a number factors which motivated the creation of ANTEL. The state saw that it was its responsibility to create an economic development strategy. This strategy meant that telephone services would be imperative in fulfilling economic initiatives. As such the state wanted to create an autonomous institution to manage the services because it was to receive much needed external aid from the World Bank to further develop the system, but only on the 
condition that an Autonomous Institution was created to serve the public interest (Decree no. 370, 1962).

However, the degree of ANTEL's autonomy was questionable as it maintained close ties to central state agencies. ANTEL's executive board, or “directive junta”, was comprised of thirteen members: the president of ANTEL who was appointed by the president of El Salvador and given a four year term; one director and one alternative director each for the Ministry of Culture and Communication, Ministry of Interior Affairs, Ministry of National Security and Defence, and the Ministry of Treasury and Economy; one director and one alternate director chosen by the national private banks, and one director and one alternate director chosen by the "agricultural, industrial, and commercial associations or organizations established in the country" (Chapter 3, Article 6A-B). The terms of the directors varied by director-type: those who were chosen by the Ministry of Internal Affairs and Treasury served three years, those chosen by the national banks served for two, and those chosen by the industries and association served one.

The initiative to reconstruct the telecom sector was ambitious. It was also one which required a heavy amount of capital that the country did not have. Since El Salvador was a country that relied heavily on agricultural exports (World Bank, 1972, p. 2), it remained at the mercy of international markets. For instance, imports and exports had slowed during the Second World War (Amill, 1947, p. 13). The price of coffee then peaked in 1957, but fell in the years leading up to ANTEL's creation (World Bank, 1962, p. 6).

Thus, foreign help proved to be crucial for ANTEL to meet its goals. In 1962, before introducing the ANTEL law, the country approached the World Bank in search of a loan. The World Bank entertained the idea, and representatives from the organization visited the country twice - once in later in the year, in March/April, to conduct an initial review of the 
Telecommunications Bureau of the Ministry of Interior, and again in February/March of 1963 "to review the engineering aspects of the project and the organization and financing plan of ANTEL" (p. 1). Later that year, and upon further review, the World Bank agreed to loan the government US\$9.5 million over the span of 32 semi-annual payments, from 1968 to 1983 , "to increase the local telephone exchange capacity and to improve [the country's] long distance service" (World Bank, 1972, p. 1). El Salvador was to expand its network to 26,000 telephone lines, cables, line networks, and long distance facilities for inter-urban connections (World Bank, 1962, p. 3).

Resources would be allocated specifically to the country's largest city centres-San Salvador, Santa Ana, and San Miguel — and would also be used to install a microwave radio system that would "connect the three cities and several smaller city centres in the country" (p. 4). From 1967 to 1970, the growth of total connected lines ranged from four to seventeen percent annually (p. 2). By 1971, thirty-five local automatic exchanges had been created with 28,434 telephone lines in service. Its telegraph service had grown considerably as it was now comprised of 200 lines with 130 subscribers (pp. 2-3). However, as Table 3.3 shows, while the system had expanded in the country, it lagged behind other Central American countries. Moreover, it lagged behind some Latin American countries such as Mexico and Argentina, as well as more developed ones.

In 1971, and in the face of increasing demand, the country looked to further expand, update, and develop its telephone system. However, as was the case nine years earlier, the initiative was one which required capital the country did not have. ANTEL had run into financial problems. In 1967, fluctuations in copper prices caused price escalations in cable contracts and a change in ANTEL's billing procedure led to many unpaid bills. Additionally, ANTEL lacked a 
Table 3.3: Total Number of Phone Lines/Phone Lines per 100 people

\begin{tabular}{|c|c|c|c|c|c|}
\hline & 1960 & 1965 & 1970 & 1975 & 1980 \\
\hline$\overline{\text { USA }}$ & $49,269,000 / 26.43$ & $58,289,000 / 29.2$ & $69,039,000 / 32.9$ & $80,515,000 / 36.7$ & $94,282,000 / 41$ \\
\hline Canada & $4,987,502 / 27.85$ & $5,269,000 / 26.75$ & $6,514,000 / 30.4$ & $8,278,000 / 35.8$ & $9,979,000 / 40.95$ \\
\hline France & $2,193,711 / 4.8$ & $3,065,000 / 6$ & $4,268,000 / 8.4$ & $7,099,000 / 13.4$ & $15,898,000 / 29.5$ \\
\hline Sweden & $2,089,300 / 27.9$ & $2,927,000 / 37.8$ & $3,603,000 / 44.8$ & $4,209,000 / 51.4$ & $4,820,000 / 58$ \\
\hline Mexico & $338,450 / 0.9$ & $494,946 / 1.1$ & $858,796 / 1.6$ & $1,644,499 / 2.65$ & $2,699,732 / 3.85$ \\
\hline Argentina & $914,656 / 4.45$ & $1,100,000 / 4.95$ & $1,287,000 / 5.35$ & $1,651,000 / 6.3$ & $1,879,000 / 6.7$ \\
\hline Costa Rica & $10,000 / 0.75$ & $20,000 / 1.25$ & $40,000 / 2.2$ & $81,000 / 3.95$ & $157,400 / 6.70$ \\
\hline Guatemala & $17,821 / 0.4$ & $24,306 / 0.5$ & $37,871 / 0.7$ & $47,583 / 0.75$ & $82,975 / 1.2$ \\
\hline El Salvador & $\mathrm{N} / \mathrm{A}$ & $12,200 / 0.4$ & $28,700 / 0.75$ & $48,100 / 1.1$ & $68,833 / 1.5$ \\
\hline Nicaragua & $\mathrm{N} / \mathrm{A}$ & $\mathrm{N} / \mathrm{A}$ & $17,000 / 0.7$ & $21,947 / 0.8$ & $30,827 / 0.95$ \\
\hline Honduras & $\mathrm{N} / \mathrm{A}$ & $\mathrm{N} / \mathrm{A}$ & $\mathrm{N} / \mathrm{A}$ & $17,003 / 0.55$ & $28,944 / 0.8$ \\
\hline
\end{tabular}

Source: World Bank (2015) World Development Indicators 
chief engineer, support staff, and had a "pending settlement of overdue accounts with suppliers" (World bank, 1972, p. 1). Thus, ANTEL looked again for external aid.

Despite the decrease in military spending, militarism continued to play a prominent role in ANTEL's operations and management. Throughout the existence of ANTEL, the state considered the military to have specific communication needs separate from the publics', and as such, established separate telecommunication facilities (World Bank, 1973, p. 2). Moreover, the 1960s saw a "lack of opportunities for younger, highly trained officers" to move into higher positions of the government because of low turnover rates in these positions. This led younger officers to be appointed to lower-ranking positions within the government and other public administration offices, such as ANTEL's board of directors (Williams and Walter, 1997, p. 94). Discontent with his presidency, a military-civilian junta overthrew President Romero in 1979 but continued to place military officers in ANTEL (p. 118). Appointment to ANTEL provided an "important source for additional income for 'deserving' officers" (p. 117). However, the country's political environment had reached a boiling point. After years of dictatorship, leftist groups were frustrated with political and economic instability and the repressive regimes that had dominated the country throughout its history. A civil war broke out at the end of the 1970s, and this would have important ramifications for the future of Salvadorian telecommunication.

With El Salvador's early history mapped out, I now turn to a discussion of the remaining four countries of this study. As will be discussed, the state has played a prominent role in each of their telecommunication systems development.

\subsection{Guatemala}

Telegraph lines were first seen in Guatemala in 1867 (Clegern, 1994, p. 48). As in El Salvador, early Guatemalan leaders sought economic development through centralization 
methods and repression. These included using the country's constitution to promote its agroexport industry and coffee oligarchies. In 1879, under Article 20 of its constitution, the state guaranteed freedom of industry while at the same time allowing state intervention on an ad hoc basis, such as securing "labor [sic], providing credits and establishing infrastructure and communications" (Bull, 2005, p. 93). Consequently, this produced monopolies within many sectors and oligarchies in numerous industries (ibid.). These initiatives attracted foreign investment into the country, and these would prove to be important for the development of telecommunication systems (p. 40). For instance, foreigners were invited to invest in the country's telephone services which, at the time, were managed by Compañia de Telefonos de Guatemala, a Guatemalan company created with German capital (ibid.; Russell, 1998, p. 45).

Guatemala underwent two long dictatorships in the first half of the twentieth century, first under Cabrera from 1898 to 1920, and then under Jorge Ubico from 1931 to 1944. Both supported initiatives for state centralization and methods to repress labour groups (Bull, 2005, p. 40). Cabrera was overthrown in 1920. In his place was a new liberal oligarch, Carlos Herrera, whose short presidency (lasting from 1920 to 1921) strengthened "the drive towards national controls of infrastructure" (ibid.). This included the creation of a new constitution in 1921 which established that "the State reserve the attributes of the postal services, the telegraph, radio telegraph, air navigation, [and] issuing of currency" (ibid.). Foreign investors continued to play a role in the country's systems, such as US-owned All American Cables Incorporated, which began operations of international telecommunication lines in 1925. In 1927, the first automatic telephones were put into service as the result of a contract with German-owned AEG. This created 2,000 phone lines with the possibility of extension to 6,000 (p. 41; Russell, 1998, p. 45). While Herrera was able to establish these important services, under his rule, the oligarchy fell 
into "political chaos that ended with the takeover by a junta dominated by military personnel" (Bull, 2005, p. 41). After "turbulent years of various military governments", Jorge Ubico, a member of the oligarchy with a military background, and "a firm admirer of Hitler's Third Reich”, became the country's leader in 1931 (Black, 1984, p. 12.). Militarization increased under his rule; for instance, he appointed military personnel to control postal services, telegraph, and radio facilities (ibid., Bull, 2005, p. 41).

Ubico was quick to construct telephone and telegraph facilities: by 1940, "the network encompassed every department of the republic with only two departments containing less than five telegraph offices" (Bull, 2005, p. 41). Ubico looked to "extend his power and control" over his newly established communication program as he was aware of the political implications that stemmed from "instant communication", but he soon realized that his endeavours were limited by state income as previous governments refused to increase taxes and accept foreign loans. (ibid.). He soon sought foreign help: the UFCO, through its subsidiary Tropical Radio and Telegraph Company (TRT), became a prominent owner in telecom infrastructure not only in Guatemala, but most of the Central American region (Drale, 2010).

By now, worker groups which included teachers, public sector employees, and industrial workers, were growing frustrated with the state. They felt that it was highly repressive; for instance, the state outlawed unions and worker strikes and deemed them "communist" or "subversive" (Black, 1984, p. 86). This culminated in a series of uprisings in 1939, and in 1944, Ubico turned over control of the country to a military junta, ushering in the era of General Federico Ponce. Ponce was later replaced by an interim junta, and in December of that year, the junta called an election where Juan Jose Arevalo, a university professor, was elected "overwhelmingly" (Bull, 2005, p. 43). Under Arevalo, a new constitution was drafted to 
decentralize most government services; however, it maintained its grasp on telecommunication. In January of 1945, "the Congress decreed the control of the telegraph, cables and radio communications" but left them foreign-owned (ibid.). The state remained as the operator of these services.

Arevalo's social reforms alienated elites. The oligarchies decided to, yet again, dispose of their leader, and Arevalo was replaced by Captain Jacobo Arbenz (ibid.). Arbenz was a "clearly nationalistic" leader who prioritized Guatemala's economic reforms over its social reforms (ibid; Simon, 1987, p. 21). As such, he spearheaded a campaign against foreign-owned monopolies in "key economic sectors" such as transportation and hydroelectricity (Bull, 2005, p. 43). Although these reforms were motivated by recommendations by the World Bank, many within the oligarchy and the US government saw Arbenz as a Soviet sympathizer (Simon, 1987, p. 21). Soon the US would embark on a propaganda campaign portraying Arbenz as a communist, and in 1954, Arbenz stepped down from the presidency (Drale, 2010). Highly influenced by the US, the oligarchy established Castillo Armas as the country's president (ibid.; Simon, 1987, p. 21).

Foreign aid was prominent in Guatemala. For instance, the US supported Armas and provided aid in the total of US\$61.8 million between 1954 and 1957 (Bull, 2005, p. 44). This, along with the World Bank and the Inter-American Development Bank, would help finance its telecommunication infrastructure (Black, 1984, p. 18). However, Armas' tenure as president would not last very long, as in 1957, he was assassinated (ibid.). Miguel Ydigoras Fuentes was elected as president, led the country to an economic recession, and was subsequently replaced by Enrique Peralta Azurdia in 1963 following a military coup. In 1964, Azurdia established the Presidential Intelligence agency, which created a Regional Telecommunication Centre "linking the National Police, Treasury Guard, Detective Corps, Government Ministry, the Presidential 
House, and the Military Communication Centre" (Bull, 2005, p. 45). This happened as the government's concession with the TRT to operate international telephone lines expired (ibid.). Taking advantage of the expired concession, Azurdia nationalized international services into "Guatel International" on January 26, 1966. (Russell, 1998, p. 45). In March of that year, his administration passed the "Law of Radio Communication" (Decree no. 433, 1966). The law centralized the management of radio spectrum to the Ministry of Communications and Public Works (ibid.). Azurdia also appointed many business elites to various commissions, resulting in increased government spending on telecommunications, which by now was comprised of more than 24,000 phone lines (Bull, 2005, p. 46; World Bank, 2015).

By 1967, the government looked to "carry out a national telecommunication expansion program" and sought aid from the World Bank (World Bank, 1971, p. 3). By now, telecommunication services were operated by three entities: Empresa Guatemalteca de Telecominicaciones Internacionales (what was formerly TRT), which managed international services, the General Directorate of Telephones, which managed local telephone services, and Postal and Telegraph Directorate (DGCT), which managed domestic telegraph service (World Bank, 1971, p. 6) The World Bank recommended that the government merge the three entities to improve overall efficacy. The merger created Guatel, the country's new, state-run telecommunication provider which was overseen by the Ministry of Communication and Public Works (p. ii, 11). Its board consisted of the Minister of Governance, the Minister of Foreign Relations, and two additional members appointed by the President (p. 11).

In subsequent years, Guatel became a main source of state income. It also increased the total number of telephone lines in the country from 47,583 in 1975 to 82,975 in 1978 (World Bank, 1986; 2015). However, political and economic instability in the 1970s forced foreign 
investors to leave the country, leaving the government scrambling for foreign capital (Black, 1984, p. 170). While at first wary of Guatemala's human rights record, the Carter administration in the US (and later Reagan) and the World Bank would assist Guatemala in a loan for the development of a rural phone network totalling \$182 million in 1982 (p. 160).

\subsection{Honduras}

Telegraph lines were first introduced in Honduras in 1880 and were used to connect "the country's most important towns and many smaller villages" (Leonard, 2011, p. 45). These also connected the country with the US and Europe (ibid.). Development of telecommunications, however, depended heavily on foreign investment; specifically, American banana farmers. Between 1905 and 1920, UFCO banana farming operations underwent expansion in the country (p. 131). As the UFCO grew, so did its political clout - throughout the 1920s, UFCO became one of many "state substitutes" which constructed infrastructure, banks, schools, and public buildings. During Lopez Guiterrez’s presidency, the company also “obtained a 60-years concession for the development of railroads and docks," and, more importantly, "a monopoly concession to operate the telegraph and telephone services through its subsidiary, TRT" (Bull, 2005, p. 132). TRT, together with AT\&T, would "offer the first commercial radio telephone service in Central America” in 1932 (Drale, 2010).

A number of civil wars unfolded in the country in the following twenty years. This helped create "a weak state and a weak private sector" throughout the 1930s (Bull, 2005, p. 133). UFCO took this opportunity to exercise its political and economic muscle. In 1932, the company loaned money to Tiburcio Carias which helped him win the country's presidency. However, UFCO later felt that the Carias government intervened too frequently in its operations (p. 132), so, together with the US State Department and Honduran elites, they deposed of Carias, whom 
they viewed as “a threat to the country's fragile political consensus, and an obstacle to modernization" (p. 133). In the following years, the country's leadership was comprised of a USbacked military junta and governments which "sanctioned state intervention in the economy" while establishing Autonomous Institutions (p. 135). Similarly to Costa Rica (discussed below), this increased the number of state employees but also raised the national debt (ibid.). These moves also alienated private businesses.

Lopez Arellano, part of a civil-military junta from 1963 to 1971, sought to reform certain sectors of the state in order to stimulate economic development. However, by 1975, his plans were jeopardized because of unexpected economic difficulties, including damages incurred by Hurricane Fifi in 1974 to the banana plantations, homes, and essential infrastructures (Leonard, 2011, pp. 154-155). An internal coup ousted Lopez as president in 1975. His replacement, Melgar Castro, enforced military rule (p. 55) all the while implementing a national development program inspired by Guatemala's "national security doctrine” (Bull, 2005, p. 138). His plan included nationalizing infrastructures and "the property and functions previously held by banana companies” (p. 139). As such, UFCO's concessions to operate telecommunication lines were terminated.

This paved way for two institutions to manage telecommunication lines: the Honduran Telecommunication Enterprise, or Hondutel, in 1976, and the Ministry of Communications, Public Works and Transport, to whom Hondutel answered (Decree 341, Chapter 5, Article 14). Hondutel was put under heavy military control, employing members of the military while providing free services to armed forces (Bull, 2005, p. 141). It was also seen as an envious institution to run, as "the position as a manager of Hondutel was seen as one carrying a high degree of prestige, and to obtain it was considered a "reward"' (p. 141). As such, from 1978 to 
1994, Hondutel saw 12 managers, none of whom "had any particular knowledge of the telecommunication sector, but ran it as a national security institution" (ibid.). Throughout this period, Honduras continued to experience social and economic crises as well as difficulties acquiring capital from foreign bodies to carry out projects.

\subsection{Nicaragua}

Nicaragua's telecommunication sector, when compared to other Central American countries, was a late bloomer. Similar to other Central American countries, Nicaragua's early telecommunication services had close ties with military. From 1944 to 1971 services were managed by the Directorate-General of Communication (DGC), an administrative department of the Ministry of Defence (Herrera, 1998, p. 53). During Anastasio Somoza Debayle's presidency in the mid-1970s, telecommunication services were merged into a newly formed state PTT called the Directorate-General of Telecommunications and Postal Services (DGTC). Management of the DGTC remained relatively unchanged in the face of a civil war and new governments - such as the 1979 Sandinistas National Liberation Front, which the US had a strong disliking tobecause "it was, after all, already owned and controlled by the state" (ibid.).

However, as the US' prominence in Central America grew in the 1970s and 1980s (Bull, 2005, p. 42), the Nicaraguan government, like other Central American governments, became dependant on US foreign aid to carry out development initiatives. The US was against the Sandinista military junta and "was directly responsible for blocking over $\$ 164$ million in bilateral and multilateral credits to Nicaragua" (Ricciardi, 1991, p. 253). This, along with a civil war, was detrimental to the country's development initiatives. From 1980 to 1989, the country struggled with a destabilized, hyper-inflated economy, which saw the GDP per capita decline an 
average of five per cent a year and caused the country’s external debt to rise to $\$ 3$ billion by 1982 (Herrera, 1998, p. 52; Ricciardi, 1991, p. 253).

In an effort to stimulate development, the Sandanistas replaced the DGTC with the Nicaraguan Institute of Postal Services and Telecommunication, or TELCOR, in June 1982. TELCOR inherited the duties of the DGTC, and while it operated as a state monopoly, it was, more importantly, not necessarily dependant on state funding as it was allowed to acquire private capital so long as it benefited Nicaragua (Decree no. 1053, 1982, Article 3G). TELCOR's management was comprised of an executive body made up of three military junta appointees who had "the legal right to direct, coordinate, control, and monitor" TELCOR's activities (Articles 5 and 6). However, TELCOR's regulatory framework was weak; Herrera (1998) writes that it had no way of setting rates, it failed to address possible challenges posed by new technologies, and it failed to address issues relating to the interconnection of domestic networks (p. 54).

Soon, TELCOR became one of Nicaragua's main sources of foreign income because, being the country's only telecommunication provider (Decree no. 1053, 1982, Article 3), it had a large stake in international calls to and from the country (Herrera, 1998, p. 53). Because the Sandinistas were still facing a trade embargo imposed by the US, the government relied heavily on TELCOR's revenues to carry out development initiatives. However, the trade embargo also prevented TELCOR from buying "modern equipment on the international market", thereby resulting in the "passing by" of "technological changes spreading through the industry elsewhere in the world" (ibid.). As a result, its services were not up to par with more developed parts of the world. 
By the end of 1993, TELCOR's telephone network consisted of 66,810 lines and 1.5 telephone lines per 100 people (World Bank, 2015). However, distribution of the service was as unequal as it was concentrated in the state capital: 63 percent of the total lines installed in the country were in Managua with a density of 5.2 lines per 100 people, while the rest of the country had only a density of 0.7 lines per 100 people (Herrera, 1998, p. 54). TELCOR addressed this inequality in 1991 with "a policy of diversification of equipment suppliers" before the onset of digital lines. In 1993, 58,000 digital lines were installed (ibid.).

\subsection{Costa Rica}

Politically speaking, Costa Rica is an outlier in Central America. Unlike its neighbouring countries, Costa Rica's early governments opted for more equitable land distribution rather than repressive class-politics (Ordonez, 2009, p. 17). It also experimented with democratic governance as early as 1889 (Bull, 2005, p. 84). However, the country has had its fair share of farmers and elites who not only derived "their economic, political and social power...from control over land, but also from control over coffee processing, credit, and commerce" (p. 83). Additionally, even though Costa Rica has never been ruled by a military junta, it did have an oligarchical government system. Unlike other countries, though, the oligarchical government opted to stimulate economic development through market regulation instead of depending on cheap labour and coercive actions (p. 84). Additionally, the class-based relationship between the private elite and the poorer public was not a typical one: private elites not only looked after their own interests, but they also established institutions aimed at generating overall economic growth and welfare for the country (ibid.). In 1848, the country's first telegraph line was built and connected Cartago with San Jose (Rankin, 2012, p. 63). 
In 1948, a Jose Figueres-led military revolt made Figueres the president of Costa Rica. The junta sent the previous oligarchs into exile and introduced social reforms (Rankin, 2012, pp. 117-118). In 1948, a new constitution gave "Autonomous Institutes" a "high degree of autonomy from the executive powers" (Bull, 2005, p. 87). One of these institutes was the Costa Rican Electricity Institute (ICE), created on April 8, 1949. It had a public service function, as it looked to "carry out a coordinated program of electrification of the country" (World Bank, 1963b, p. 1). Unlike other Central American countries, its board was comprised of private and state representatives, as well as various other civil society organizations (Bull, 2005, p. 48). By 1949, Costa Rica had undergone multiple social reforms, including "the abolition of the army [and] the establishment of extensive social security and public health systems" (Ordonez, 2009, p. 21). As Ordonez argues, these reforms were important for the country's economic future as they "marked a dynamic period of three decades in which Costa Rica almost quadrupled its national income and per-capita indicators" (ibid.).

During his second presidential term in 1953, Figueres put strong emphasis on the development of national energy sources through ICE (Rankin, 2012, p. 122). In 1961, his close friend Fransisco Orlich became president, and although more conservative than Figueres, Orlich continued the country's developmentalist policies, and "among his main accomplishments was the continued development of a national plan of electrification and telecommunications" (Bull, 2005, p. 89). Olrich gave ICE the "responsibility of providing telecommunication services in Costa Rica" in 1958 (World Bank, 1963, p. 1). Additionally, the government amended the constitution which prohibited it from gaining profits collected from ICE, stating that "the institute should not be considered a source of generation of funds for the government" (Bull, 2005, p. 87). 
However, in the early 1960s, Costa Rica faced a service shortage as it had only 10,000 active telephone lines in the country, about 0.74 lines per 100 people, and were "badly overloaded and obsolete" (World Bank, 1963b, p. 4; 2015). They were all located in the nation's capital, San Jose, and were owned by a foreign investor: The National Energy and Light Company (CNFL), a subsidiary of General Electric-owned EBASCO. To address the service shortage, the Legislative Assembly passed legislation in 1963 which merged the infrastructure operated by CNFL with ICE. This gave ICE a "constitutional monopoly on owning and operating telecommunication infrastructure" in Costa Rica (Bull, 2005 p. 89). ICE subsequently started plans to expand the telephone network across the country and, like the other Central American countries, sought help from the World Bank (World Bank, 1963b).

However, in the following years, "a large part of the population was still marginalized", which resulted in the state to interject in ICE's operations (Bull, 2005, p. 91). For instance, in 1970, Figueres, who was now serving a third presidential term, proposed measures to reduce ICE's autonomy by restructuring its board of members. Thereafter it came to consist of "four members of the current government and three from the opposition party" (p. 93). In 1974, the Law of Executive Presidents no. 5507 established a new position of "Executive President to the Government". ICE was now comprised of an "executive president, a general manager and two dub-directors, one for the electricity part and one for the telecommunication part" (p. 95). However, increased state activities in autonomous bodies, such as ICE, came at a cost, as the country had reached a debt crisis by 1980 (Rankin, 2012, p. 137). The state looked to the World Bank for financial help, but the World Bank pressured Costa Rica to separate ICE's telecommunications and electricity operations for two reasons. First, it would allow the World Bank to differentiate where loans made to ICE were allocated, and second, with the looming 
possibility of telecom privatization, it would allow the World Bank to determine whether or not to continue aiding telecom development (World Bank, 1983, p. 14). In total, by 1980, The World Bank had made Costa Rica five loans to help assist in telecommunication development (p. 2).

\subsection{Conclusion}

To conclude, the early history of telecommunications in El Salvador and Central America is defined by three overarching themes: first, the prominence of liberal, military dictatorships allowed states to operate telephone networks. This allowed governments to further their grasp across countries through promoting agro-exports; in the case of El Salvador, it became a coffeeexporting power house in its early years. Therefore, these dictatorships served the interest of business and social elites more often than the publics'.

Secondly, and as a consequence, because states failed to maintain their networks, governments in the region relied heavily on external aid, either from private companies such as UFCO or international institutions such as the World Bank, to upgrade and develop their networks. The reliance on the latter would be instrumental in the creation of autonomous institutions (such as ANTEL in El Salvador) which allowed countries to receive aid from international institutions. These relationships were enduring, and as the next chapter will discuss, carried consequences that would shape the region's landscape in the $21^{\text {st }}$ century. Curiously, even after autonomous institutions were created, telecommunication networks remained closely tied with governments as they were managed by military heads.

Third, in spite of private and international actors intervening, poor quality of services continued to plague the region. An important lesson to take away from this theme is that the "digital divide", or in this chapter, the "access divide", existed within El Salvador and 
surrounding countries long before the advent of digital technologies. Indeed, services were scarce throughout the region and the quality of these services declined throughout the century. In the 1970s leading into the 1980s, as fluctuating agro-export prices (specifically coffee) in international markets inhibited economic grown, which factored into the deterioration of networks, a civil war broke out in El Salvador.

In the following chapter, I will discuss the second half of this history which consists of telecommunication liberalization, privatization, and reform within the region. I will pay particular attention to how this process has unfolded in El Salvador. 


\section{Telecommunication Policy Reform in Central America, 1979 - 2013: \\ Change or Déjà Vu?}

For most Central American countries, telecommunication reforms in the 1990s were part of much larger national political and economic initiatives. Many of the countries were coming out of civil wars and looked for ways to generate revenue to assist in public service projects. Telecommunication privatization was attractive in this regard because it was seen as a way to stimulate economic growth as well as a way to facilitate the development of infrastructure that would support the economy and other social and political policy objectives (Argumedo, 2007, p. 13). In the Central American case, telecommunication reform relied heavily on foreign investment from industrialized countries, such as the US, the UK, Spain, and France. Much of the region promoted telecom privatization by opening the sector to foreign investment. Most countries did this in conjunction with enterprise privatization, while one, Costa Rica, chose to not privatize its enterprise, and only liberalized its sector in the late $2000 \mathrm{~s}$.

This chapter carries on from chapter three by exploring the later history of telecommunication in Central America, and specifically, El Salvador, from 1970 to 2013. In doing so, it will discuss the processes of privatization, liberalization and regulatory reform that have underpinned the transformation and development of telecommunications in Central America. In this process, all five countries created regulatory bodies. Four were created between 1995 and 1996 (El Salvador, Guatemala, Nicaragua, Honduras), while Costa Rica waited until 2008 to do so after strong opposition to privatization and liberalization initiatives. Before turning to a fuller explanation to these events, however, the chapter begins by discussing the significant role that international lending institutions such as the International Monetary Fund (IMF) and the World Bank played in telecommunications reform across the region. 


\subsection{International Institutions}

As noted in the previous chapter, the role of international lending institutions has been significant in Central America's development. As it had done throughout the first half of the twentieth century, the World Bank provided financial aid to developing countries in their telecommunication endeavours, but this financial aid was often provided with conditions. Indeed, the composition of these institutions would dictate whose interests were being favoured in the reform process.

Jill Hills (2007) writes that these institutions have strong Western influences underpinning them. The IMF has traditionally been headed by a European. The World Bank has been headed by an American ever since its inception in 1944. During telecom reforms in the 1980s and 1990s, the World Bank played heavily to Western interests, specifically American interests by becoming "party to the US goal of opening up foreign domestic telecommunication markets to US capital” (p. 149). Between 1977 and 1982, US firms benefitted greatly from World Bank contracts receiving a total US \$3.4 billion, "the majority going to consulting and engineering firms" (p. 151).

For much of the 1980s, the World Bank's agenda focused less on poverty alleviation and more on private sector investments. Alden Clausen, a previous head of the Bank of America who was appointed Head of the World Bank in 1981, was a strong advocate for this change (p. 153). By the end of the 1980s, "the neoliberal 'Washington Consensus' between the World Bank, IMF, US Treasury, and Wall Street had placed privatization at the core of development policy," despite some South American countries, such as Colombia, Uruguay, Brazil, and Argentina, either 1) being opposed to privatization, or 2) having undergone failed privatizations (p. 162). American companies that expressed interest in investing in the region included BellSouth, Bell 
Atlantic, G.T.E., Nynex International, US West, Cititel, and Continental Telephone (Petrazzini, 1993, p. 149). This discussion will be incorporated into the following sections of this chapter as it is difficult to dismiss the embedded interests which existed between the lending institutions, transnational companies, and the Central American countries.

\subsection{Introduction of Democratic Reforms}

El Salvador's civil war carried on throughout the 1980s and the early 1990s between the state and a leftist group, the Farabundo Martí National Liberation Front (FMLN). The war's longevity was due in part to the country's geopolitical position in relation to the cold war. It received large amounts of military funding from the west, particularly the US, which sought to halt the spread of what the U.S. referred to as the "communist reign of terror" that had been unfolding in Nicaragua with the Sandinista revolution (Reagan, 1985, p. 279). From 1980 to 1990, the Salvadorian armed forces grew from 7,250 troops to 44,600 (Williams and Walter, 1997 pp. 139-142). This prolonged the war and destroyed much of the country's infrastructure, including its telecommunications network.

At the same time that the country was receiving military aid from the US, ANTEL was in the midst of receiving a six-year World Bank loan of US \$23 million, disbursed in 1978. As noted in the previous chapter, this was one of many loans made by the World Bank to the country. Similar to Reagan's concerns regarding communism, the World Bank issued loans "to counteract the influence of the Soviet Union on less developed countries" (Hills, 2007, p. 150).

Unlike its two previous loans, ANTEL was plagued by obstacles in allocating the third loan. These were mainly due to 1) the ongoing civil war, and 2) the lack of adequate management at ANTEL's highest levels. These were issues that the World Bank (1990) 
acknowledged in its Project Completion Report. The World Bank issued the loan with the intent of increasing the total number of phone lines by 11 percent throughout a six-year period. However, because the war affected the process of constructing lines, "the average growth actually achieved was around 7 per cent" (p. 14). Between 1978 and 1982, only 21,760 phone lines were added to the country's telephone network, far short of its target of 36,000 phone lines (ibid.). Adding to these setbacks was the World Bank's limited supervisory role over the project—which it itself acknowledged as "inadequate". Its final supervisory visit was in September 1982, two years before the loan's closing date (p. 15). By the end of the project, the World Bank had barely achieved two-thirds of its goal.

After more than a decade of civil unrest, peace was on the horizon. Following numerous failed attempts to sign a peace accord in the 1980s, on January 16, 1992, representatives from the Salvadorian government and FMLN met in Chapultepec Castle in Mexico City to sign a peace agreement mediated by the United Nations, ending the civil war (Williams and Walter, 1997, p. 151). As Williams and Walter note, the agreement committed the country to democratic reforms that would pave the way for its political and economic future:

[t]he accords represented an important step toward a genuine process of democratization and national reconciliation. More specifically, they provided a unique opportunity for subordinating the armed forces to civilian control, thereby dramatically reversing the military's traditional role in politics (ibid.).

After the 1992 peace accord, the military's role in politics was substantially reduced; instead of being a main political actor, its role was limited to one of national defence and, domestically, it would be deployed only in situations of "national emergencies [using the] principles deriving 
from the rule of law" and "the primacy of the dignity of the human person and respect for human rights" (p. 152; United Nations, 1992, p. 3). Furthermore, the size of the armed forces was significantly reduced from 46,600 troops in 1991 to 30,500 in 1994 (William and Walter, 1997, p. 163). The accords also introduced a doctrine that "stressed the pre-eminence of human dignity and democratic values, respect for human rights, and subordination to the constitutional authorities" (United Nations, 1992, p. 4). Aside from military reforms, they also created a new civilian police force as well as electoral, judicial, and socioeconomic reforms (pp. 29-36).

The peace accord paved the way for a post-militarism era that saw initiatives to economically and socially rebuild the country. El Salvador's telecommunication infrastructure had incurred US $\$ 1.6$ billion in damages, and this had effects that rippled into other sectors (Argumedo, 2007, p. 13). Agro-exports remained as important to the Salvadorian post-war economy as they had been pre-war and, as was the case before the civil war, it relied on telecommunication to promote agro-exports. Damaged telecommunication infrastructure, underdeveloped networks, and poor geographic coverage made promoting this initiative difficult (p. 14). In 1993, the World Bank conducted an investigation to measure the damages and evaluate the system and found that, in general, services were expensive and inaccessible. Additionally, when compared to other Central American countries, the country's telephone service lacked penetration —in 1993, the telephone density was 5.5 per 100 people (comparatively, Costa Rica's was 12 per 100 people) and was plagued by congestion problems. The wait time to connect was two years and moreover, thirty-five per cent of calls made within the country were not completed due to heavy traffic (ibid.). It was clear that a damaged telecommunication infrastructure would affect larger economic issues and would also affect 
social initiatives as an adequate system was needed to promote foreign investment and facilitate agricultural exports (ibid.).

These issues were foreseen during the civil war. The government of 1989, led by Alfredo Christiani, implemented an economic strategy that aimed to address connectivity issues, and five years later, his government enacted a social development plan. Both plans included efforts to restructure telecommunication services and heavy investments into ANTEL. With respect to the latter point, between 1990 and 1993, the country invested US \$171.96 million. As Table 4.1 shows, investments would only continue to grow from then on. By 2000, El Salvador would invest US \$875.62 million on telecommunication services, much more than its neighbouring countries. Costa Rica would be the closest to match it with US \$118.6 in investments (Table 4.1).

Table 4.1: Annual Investments in Telecommunication Services (Million US Dollars)

\begin{tabular}{|l|r|r|r|r|r|r|}
\hline Country & $\mathbf{1 9 9 0}$ & $\mathbf{1 9 9 2}$ & $\mathbf{1 9 9 4}$ & $\mathbf{1 9 9 6}$ & $\mathbf{1 9 9 8}$ & $\mathbf{2 0 0 0}$ \\
\hline El Salvador & 39.7 & 54.73 & 64.48 & N/A & 476.97 & 875.62 \\
\hline Costa Rica & 33.19 & 63.3 & 91.66 & 115.6 & 154.5 & 118.6 \\
\hline Honduras & 70.4 & 41.59 & 83.64 & 115.19 & 64.47 & 49.66 \\
\hline Nicaragua & 8.26 & 42.49 & 36.29 & 40.66 & 0.63 & 6.07 \\
\hline Guatemala & 11.15 & 41.95 & N/A & N/A & N/A & N/A \\
\hline
\end{tabular}

Source: ITU (2013) World Telecommunications Indicators Database

Tables 4.1 and 4.2 reveal a curious relationship between investments made in the Central American sector and phone density. For instance, Nicaragua had only begun to make heavy investments into telecom in 1992, much later than its Central American neighbours. However, between 1992 and 1994, it had "achieved the highest rate of investment and modernization of telecommunications in the whole of Central America", with investments totalling US \$103.9 million. A large portion of this, 72 per cent, was "earmarked for the acquisition of infrastructure 
and equipment" (Rivera, 2008, p. 55.) which more than doubled its number of phone lines between 1990 and 1995 with help from AT\&T. Similar to previous deals with Western-backed bodies, though, the deal had a trade-off: AT\&T was allowed to create thirty-six circuits between Nicaragua and the US which allowed it to expand its international services into the country (Penton Business Media Inc., 1990). By 1998, investments had tapered off before growing again in 2000.

While still having less phone lines than its neighbouring countries, Nicaragua's stateowned enterprise (Telcor) possessed "the most modern" telecommunication equipment within the region (ibid.). This was also due in part to the financial aid it was receiving, with the World Bank, International Development Bank, and the IMF providing aid on the condition that Nicaragua undertake sweeping telecom reforms. All was not well, though, because while the country had managed to tame its inflation rates, it still had "one of the highest per capita levels of external debt in the world" in the mid-1990s (Herrera, 1996, p. 55). Honduras, on the other hand, had spent the most within the time frame but significantly trailed behind Costa Rica in fixed-line density, with a density of 2.87 per 100 people. By 1995, El Salvador had the second highest phone line density with 4.95 lines per 100 despite having spent hundreds of millions of dollars less than Honduras (Table 4.2).

Table 4.2: Total Number of Phone Lines/ Phone Lines per 100 People

\begin{tabular}{|l|r|r|r|}
\hline & $\mathbf{1 9 8 5}$ & $\mathbf{1 9 9 0}$ & $\mathbf{1 9 9 5}$ \\
\hline Costa Rica & $209,930 / 7.8$ & $281,433 / 9.15$ & $478,939 / 13.75$ \\
\hline El Salvador & $90,496 / 1.8$ & $124,969 / 2.3$ & $284,777 / 4.95$ \\
\hline Guatemala & $128,179 / 1.6$ & $190,218 / 2.1$ & $286,352 / 2.85$ \\
\hline Honduras & $45,903 / 1.1$ & $88,038 / 1.8$ & $160,819 / 2.85$ \\
\hline Nicaragua & $43,364 / 1.15$ & $46,328 / 1.1$ & $96,611 / 2.1$ \\
\hline
\end{tabular}

Source: World Bank (2015) World Development Indicators 
Privatization was seen as a way to increase service distribution while generating profits for countries. In El Salvador, it was not until 1995 under President Calderon Sol of the rightwing ARENA party that the future of telecommunication hinted at privatization (Bull, 2005, p. 70). Under the leadership of Alfredo Mana Lagos, the "free market" model was introduced to many sectors, including the telecommunication sector (Raventos, 1998, p. 39). Telecom reform was part of Lagos' larger four-part modernization program which consisted of: 1) the decentralization of services from the state, 2) the reduction of bureaucracy through the elimination of "unnecessary ministries", 3) deregulation of sectors, such as electricity and communication, and 4) the privatization of multiple sectors "with the sole purpose of achieving efficiency" (ibid.).

The government was advised by two well-known economists. First was Pablo Spiller, whose ideas "were based on experiences from Chile and New Zealand", experiences that were ridden with problems, as their privatizations resulted in "prolonged lawsuits delaying competition" (Bull, 2005, p. 71). Second was the economist Tom Hazlett, who acted as the Chief Economist for the Federal Communications Commission from 1991 to 1992 (George Mason University, 2006). They were tasked with restructuring ANTEL in a way that "would open the telecommunication sector to competition almost immediately and deregulate all prices except the price of critical components" (Raventos, 1998, p. 40). Thus, in 1994, the Presidential Commission for the Modernization of Public Services (CPMSP) was formed and was tasked with overseeing the privatization and decentralization of sectors (Argumendo, 2007, p 15). The CPMSP viewed telecommunication as the face of these reforms (p. 16). Initially, the plan was comprised of splitting ANTEL into two vertically integrated companies (Raventos, 1997, p. 39). This plan was scrapped, but privatization of ANTEL did eventually split into two bodies that 
overlooked different services. The privatization process was, as Argumedo outlines, a three-part process consisting of decentralization (or as he calls it, "deregulation"4), restructuring, and privatization (p. 16).

\subsection{Regulatory Reform}

The first part of the process was sector regulatory reform, which brought the decentralization of enterprises. In El Salvador, this started with ANTEL in 1996, but not everyone was satisfied with the course that telecommunication was taking. Opposition to privatization came from the FMLN (which had now become a left-wing political party) and labour unions such as the Salvadoran Association of Telecommunication Workers (ASTTEL). The FMLN opposed the initiatives and argued that instead of being sold to foreign companies, ANTEL would be better off modernized (El Diario de Hoy, 1997 qtd. in Research Directorate, Immigration and Refugee Board, Canada, 1997). The FMLN argued that while it would support telecom reform initiatives, it would only do so by promoting capitalist initiatives alongside "social justice" ones. This meant pushing for legislation that would promote competition but also pushing for ones that created close ties with businesses to promote economic development (La Nacion, 1996a). They also thought that the reforms proposed by ARENA were too rushed.

Labour unions, such as ASTTEL, staged protests throughout San Salvador as they saw privatization as a threat to almost half of ANTEL's 6,000 jobs (La Nacion, 1996b). On March 18,1996 , two thousand of its members rejected a proposal to privatize ANTEL. While not completely against the idea of reforms, Wilfredo Berrios, an ASTTEL director, opposed privatization on the grounds that it would jeopardize ANTEL's "social function" of providing

\footnotetext{
${ }^{4}$ Some scholars are hesitant to use the term "deregulation" as more often than not, the process of telecom reform requires a transformation in the form and goals of regulation rather than their elimination, as the concept of deregulation implies.
} 
telecommunication services to rural areas - despite the fact that penetration levels in the rural areas of the country were incredibly low. He also argued that privatization would place importance on profits over public service functions, and, moreover, ASTELL saw the privatization of ANTEL as part of an initiative that threatened the country's economic future (ibid.). Wilmer Erroa Argueta, the national and international secretary for ASTTEL, saw ANTEL's privatization as part of a larger initiative to privatize many state-run enterprises and to turn El Salvador into a maquila-based economy. Argueta stated that the President's greatest interest was to turn the country "into a giant sweatshop", noting that the economic goals behind ANTEL's auction would be counterintuitive to the country's development policies. Telecom privatization indirectly promoted maquilas, and Argueta warned that maquilas had "not brought about social or technical development in any country in the world" (Haq, 1996).

Opposition to privatization was not unique to El Salvador. In fact, it was a concern shared by other Central American countries as well. For instance, in Honduras, USAID pressured the Jose Azcona government to privatize all fifteen of CONADI's ${ }^{5}$ companies, which included businesses in a variety of "vital" sectors, such as "forestry, sugar, textiles, food, cement, [and] paper," to reconstruct the state (Bull, 2005, p. 138). By 1986, twelve of its fifteen companies had been privatized (p. 144). Many within the private sectors denounced the privatizations and USAID's pressure on the government because, similar to El Salvador, they saw the initiatives as ones aiming to turn Honduras into a maquila-based economy (ibid.).

In Nicaragua, opposition to Telcor's privatization came from the left-wing FSLN party, Telcor union workers, and the general public, who felt that the privatization initiative was too

\footnotetext{
${ }^{5}$ CONADI was a "semi-autonomous state development agency which would provide state guarantees to promote private investment” (Bull, 2005 p. 138)
} 
rushed. The IMF and World Bank pressured Nicaragua to reform Telcor, going as far as making reform a condition for financial aid. As a result, the government complied with the IMF and World Bank's demands. The government framed Telcor's privatization "as a solution ... for indemnity on properties confiscated by the Sandinista government" (Rivera, 2008, p. 55). The state argued that revenues generated by Telcor's privatization could be used to compensate landowners who had had their properties unfairly confiscated. To this effect, a "bonds compensation system" was created in October 1992, and key to this system was the stipulation of Telcor's privatization within four years (Herrera, 1996, p. 55). Union workers rejected this argument, saying that Telcor was profitable as a public entity and that "co-investment" rather than privatization should be explored (Ansorena, 2007, p. 10; Revista Envio, 1995). They also argued that the state had adequate financial resources to address indemnities without Telcor's privatization and demanded an audit of the privatization (Revista Envio, 1995).

In Costa Rica, opposition came from the public and its legislature. A second World Bank Structural Adjustment Program was negotiated in 1988 which provided "an important backdrop to the proposal to privatize ICE" (Bull, 2005, p. 99). The telecommunication part of ICE was to be separated from the entity and create the Costa Rican Telecommunication Company (ECOTEL) in which ICE would retain forty per cent ownership while sixty per cent would be left for private investors. However, this plan fell through in the face of "fierce resistance from the unions and the general public" (p. 100). A second privatization plan was concocted to develop cellular telephony. This would be accomplished by ICE and Millicom creating a jointventure to bring mobile services to the country. In 1989, Millicom began to operate mobile services after establishing a special concession with ICE (a concession originally signed with Comcel which was later transferred to Millicom) (Raventos, 1998, p. 49). However, in 1994, the 
Supreme Court found the 1989 concession made with Comcel to be unconstitutional. As a result, Millicom ceased to operate in the country in 1995 (ibid). With two failed attempts at privatization, ICE was still the only telephone service provider in the country. Subsequent attempts to reform ICE, including privatizing and separation of its telecommunication and electricity functions into ICEtel and ICElec in 2000, were met by mass protests staged by ICE union workers, backed by strong support from students (Bull, 2005, pp. 115-116).

On the other hand, private businesses favoured telecom privatization in Guatemala, although at the objection of the IMF. As part of a wider initiative for sector reforms, the IMF was concerned with the country's fiscal stability and suggested that it reduce deficits by raising taxes (p. 49). Private businesses opposed this suggestion, instead arguing that fiscal stability could be brought by privatizing state enterprises. Opposition to reform, however, came from those within the military. Some within the military were still staunch supporters of military dictatorships. Decentralizing telecommunication services would mean losing control over a vital national infrastructure (p. 52).

Despite protests, privatization and liberalization plans moved forward. El Salvador moved toward decentralization as well. This part included selling ANTEL, but to facilitate this process, the necessary laws, regulatory framework, and financial institutions needed to be established. This was important so that the country did not repeat mistakes made in other Latin American countries. For instance, privatization initiatives in the late 1980s in South American countries such as Argentina and Chile "boomeranged" on both investors and on the networks themselves (Petrazzini, 1993, p. 149; Hills, 2007, p. 156). Argentina had adopted a "regulatingby-doing" approach to its sector "which created such an unstable and chaotic policy environment that, instead of increasing confidence of potential investors, it generated a sense of insecurity, 
scaring away precisely those companies that the government wanted to attract the most" (Petrazzini, 1995, p. 149). In Chile, privatization without oversight created a drain on Chile's central bank (Hills, 2007, p. 156). Moreover, privatization did not bring substantial growth in service distribution in neither Argentina nor Chile.

As Table 4.4 below shows, in the ten-year span of 1980 to 1990, fixed line subscriptions saw hardly any growth. Moreover, the waiting list for fixed-line services was long in both countries; in Argentina, it hovered around 1 million, in Chile, it actually increased as the decade went on. Public payphone distribution did not grow either. In Argentina, the government tried to implement policies to regulate the sector place after it had already been privatized and liberalized. As a result, Telefonica and Telecom were able to resist policy intervention as they had already become established providers (Manzetti, 2000, pp. 99-100). The lesson learned was that privatization alone was not a solution for problems. A strong regulatory structure was needed in order for privatization to achieve any desired goals.

To this effect, the government of El Salvador established a new law in Decree no. 808 , the Law of Telecommunication. The law promoted sector competition and also established a new regulatory entity called the "Superindencia General de Electricidad y Telecomunicaciones", or SIGET. This body would be (and is, at the time of writing) in charge of enforcing the country's telecommunication framework (Argumedo, 2007, p. 19). This framework established telephony as a "public service", prohibited anti-competitive practices, automatically created 30-year long concessions with telecom operators (Ley de Telecomunicaciones, Article 7), and, important for competition, required operators to share their networks on an as-needed, negotiated, basis 
Table 4.3: Fixed-line Subscriptions, Waiting lists, and Public Payphone Penetrations in Argentina and Chile, 1980-1990

\begin{tabular}{|c|c|c|c|c|c|c|c|}
\hline & & 1980 & 1982 & 1984 & 1986 & 1988 & 1990 \\
\hline \multirow{3}{*}{ Argentina } & Fixed-line Subscriptions per 100 & 6.68 & 8.15 & 8.7 & 9.28 & 10.01 & 9.28 \\
\hline & Waiting list for fixed Phone Lines & 934,000 & 951,730 & $1,000,000$ & $\mathrm{~N} / \mathrm{A}$ & 789,336 & 775,000 \\
\hline & Public Payphones per 1000 & 0.51 & 0.67 & 0.68 & 0.75 & 0.81 & 0.69 \\
\hline \multirow{3}{*}{ Chile } & Fixed-line Subscriptions per 100 & 3.24 & 3.5 & 4.03 & 4.52 & 4.9 & 6.54 \\
\hline & Waiting list for fixed Phone Lines & 150,000 & 112,932 & 178,348 & 228,420 & 236,469 & 310,267 \\
\hline & Public Payphones per 1000 & 0.76 & 0.79 & 0.79 & 0.83 & 0.93 & 1.28 \\
\hline
\end{tabular}

Source: ITU (2013) World Telecommunications Indicators database 
(Article 9, 22). Thus, with the safeguards in place to promote sector competition, Decree no. 808 was considered to be one of the most liberal of its kind at the time of its enacting in Central America (Raventos, 1997, p. 40). Since its creation, the Law of Communication has undergone multiple revisions to adapt to the ever-changing communication landscape. For example, Article 8 was altered in 2010 so that SIGET was given control to set the prices of tariffs for "basic public fixed-line and mobile services" according to international norms (Article 8).

The establishment of SIGET brought optimism to the sector's future. However, as Funes (2002) outlines, SIGET's early years were tense ones as it clashed with government and private businesses. The composition of its board members affected its ability to enforce its regulations (pp. 115-117). The Law of Communication established that SIGET's authority lay with its board of directors, which was (and presently is) comprised of three persons: one director (who also acted as superintendent) appointed by El Salvador's president, one director elected by private sector trade associations through the National Private Enterprise Association, and one director appointed by the Supreme Court of Justice. Directors serve terms lasting seven years; however, in its first nine years, SIGET saw four superintendents come and go (Rivera, 2008, p. 63). This was due in part to SIGET having a director appointed by the private sector on its board of directors. As Rivera writes,

in Latin America, there is much discussion regarding the possibility of the governments exerting pressure on the telecommunications regulatory body to favour short-term interests. Instead, in the [Salvadorian] case concern arises over the regulatory body being subject to the influence of the private sector (ibid.). 
The government also contracted the American investment bank, Citibank, to assist in the financial aspect of the transaction (Argumedo, 2007, p. 17). The presence of American banks was common in Latin American privatization initiatives, as "the World Bank's interests in Latin America coincided with those of primarily US commercial banks, seeking to exchange their poorly performing debt for performing assets"(Wellenius, qtd. in Hills, 2007 p. 163).

Other countries followed similar paths towards reform. In Guatemala, reforms came at the behest of the IMF which made it a condition for financial aid (Bull, 2005, p. 50). President Rios Montt signed an agreement with the IMF to raise taxes in an effort to bring fiscal stability to the country (p. 49). Subsequently, the tax increase factored into his downfall, and he was replaced by the Defence Minister, Oscar Mejia Victores. Victores went against the IMF's agreement and awarded 146 million quetzals to private enterprises and in turn worsened the country's economic environment (p. 50). The IMF suspended the agreement in July 1984, and, given the influence of the private sector on the country's economy, it quickly learned that subsequent negotiations required private sector input. Negotiations that followed between the government, private sector, and the IMF included discussions on privatization. Happening alongside these events was Mejia Victores' initiation of democratic reforms (ibid.).

It was not until the early 1990s that Guatemala considered restructuring its telecommunications sector, although it had brought the idea of privatizing Guatel before its congress multiple times (Russell, 1996, p. 46). It delayed reform initiatives, and unlike other countries which were downsizing the size of government agencies, Guatel increased the size of its staff from 4,939 to 5,333 between 1992 and 1993 (p. 47). Moreover, from 1987 to 1993, the country saw a significant increase in telephone lines: the number of public telephones shot up 88 per cent, from 1,096 to 2,062 public phones, and the number of telephones grew from 138,222 to 
231,090 (p. 48). Additionally, while services did not extend to all cities and towns, they covered all of the country's twenty-two provinces (ibid.).

However, the desire to privatize Guatel remained on the government's agenda. After many failed attempts, it finally went ahead with privatization initiatives in 1997 with Legislative Decree no. 94-96, the General Law of Telecommunications. This paved the way for the creation of Telecomunicaciones de Guatemala, S.A., or Telgua, which received 85 per cent of Guatel's assets. Guatel was left to serve rural areas of the country (Bull, 2005, p. 67; Rivera, 2008, p. 58). A new telecommunication regulatory body, the Superintendent for Telecommunications (SIT), was also created (p. 66).

While reform initiatives were going smoothly in Guatemala, Honduras' initiatives were hitting speed bumps. Privatization in Honduras began in 1995 as part of the country's overall “capitalization process" (Rivera, 2008, p. 59). However, the lack of transparency around enterprise privatization and the government itself drew criticisms from transnational investors, a reputation that continued into the 1990s and 2000s. The country's military governance was in part responsible for this. It was against privatizing Hondutel because it benefitted from controlling access to communication services - it was reported that the military made free calls worth 29 million lempiras in 1995 (La Nacion, 1996c). Nevertheless, telecom reform was considered in the 1990s as part of larger reform plans. For instance, Callejas' presidency in 1993 privatized 36 state-owned companies and initiated talks to privatize Hondutel (Bull, 2005, p. 147). These talks did not result in privatization, but they did spur conversations around cellular services. In 1995, Celtel, after having made three previous attempts, was awarded a concession to operate the A band (p. 148). At the same time, President Carlos Roberto Reina was elected in 1994. Reina promised to "combat corruption and end military dominance over Honduran 
political and economic life" (ibid). In May 1994, he issued a statement to Hondurans saying that a commission to privatize Hondutel had been established. While Hondutel was valued at US $\$ 800$ million, the government intended to only sell 47 per cent of it for US $\$ 372$ million (ibid.).

Reina inherited an immense foreign debt from Callejos-113 per cent of GDP and 30 per cent of the government's revenues went to repaying it. To alleviate this load, the World Bank signed a third restructuring agreement which, as was common with World Bank structural agreements, obliged Honduras to restructure its telecommunication services (p. 151). Thus, on October 31, 1995, a new telecommunication framework was enacted by the government, the first of its kind in Central America (p. 152) which brought three important stipulations to the country's telecommunication services: first, it gave the Secretariat of Public Works and Transports the power to regulate services ${ }^{6}$. Second, it created the country's telecommunication regulator, the National Commission of Telecommunications, or CONATEL, which responded to the Secretariat of Public Works and Transports (Tabora, 2007, p. 11). Third, it put Hondutel and companies of interest in charge of managing and operating services (ibid.). Hondutel was given a ten-year concession "to continue operating the services it had at the time of the law's enactment". The concession would be extended to twenty-five years and was made "exclusive but with conditions" (pp. 11-12). This clause allowed "expert intervention" into the sector in order to complete development objectives (Decree no. 244-98, 1999). The law also opened the possibility to the future privatization of the sector. While financial issues were a driving force in Guatemala's reform, they were even more so in Nicaragua.

\footnotetext{
${ }^{6}$ This power was later given to the President of the Republic in October 1997.
} 
Reform in Nicaragua came, as it had in other countries, under the guidance of the World Bank. The World Bank recommended that the country divest itself from state-owned enterprises, like Telcor, to raise the country's economy (World Bank, 1994, para. 21). Thus, Nicaragua sought to sell Telcor as a monopoly. Telcor's union workers were against this initiative, saying that "although no monopoly is good, a private one more easily escapes social control and implies a worsening of consumer service relationships, almost always to the consumer's detriment" (Revista Envio, 1995). The Nicaraguan state presented the monopoly option as one imbued with long-term goals: the winner of the auction "had to pledge to meet network expansion goals", which included the improvement of services "and creation of a technological platform...to allow interconnection and thus increase the participation of other operators once the exclusivity period was over" (ibid.). The auction was delayed for years because of the passage of Law 169 on January 19, 1994, which made it necessary for the legislature to approve "the specific proposed privatization, the creation of a regulatory entity, and the regulatory framework" before a stateowned enterprise could be sold (Herrera, 1998, p. 55).

The restructuring process required the enactment of two laws: The Law of Telecommunications and Postal Services, and the Ratification of Legal Instruments to Incorporating Individuals in the Operation and Expansion of Services (pp. 55-56). The first of these laws addressed the development of telephone services and paved the way for the creation of a new regulator, the Nicaraguan Institute of Telecommunications and Postal Services, or "Telcor" (not to be confused with the telecommunication service provider) (p. 56). Telcor was tasked with managing the level of competition within the sectors (ibid.). The second of these laws required that the new company "provide nationwide telephone services", and, to this end, it had to provide six telephones for every 100 people by the end of 1997, an ambitious target which 
required the company to triple the levels of access to telephone service in two years considering that access levels in 1995 was 2.07 per 100 in 1995 (Table 4.2). One final stipulation of the privatization was that Telcor could not be completely auctioned off. It would be split into three groups of shares: forty percent would be sold, eleven per cent would go to employees, and the remaining forty-nine per cent remained with the state as the Nicaraguan Telecommunication Company (ENITEL) "for subsequent sale on the democratic or international stock market" (Rivera, 2006, p. 55). Like other countries, Nicaragua's privatization plans were in full swing.

While it may have been popular throughout the 1990s, not all countries elected to follow the privatization doctrine. Costa Rica, for instance, did not privatize any telecommunications services, thereby maintaining the government's monopoly on all services for much of the 2000s (Rivera, 2008, p. 51). Nonetheless, the country faired very well within the region in terms of phone line densities. At times, it fared even better than countries that underwent privatization, as we saw in relation to fixed-line telephone service in Table 4.2 above and as Table 4.3 below shows in relation to mobile phone service.

Table 4.4: Total Mobile Phone Subscriptions/ Mobile Phone Subscriptions per 100 People

\begin{tabular}{|l|r|r|r|r|r|}
\hline & $\mathbf{1 9 9 5}$ & $\mathbf{2 0 0 0}$ & $\mathbf{2 0 0 5}$ & $\mathbf{2 0 1 0}$ & $\mathbf{2 0 1 2}$ \\
\hline & & $155,271 /$ & $1,281,462 /$ & $9,505,071 /$ & $7,370,034 /$ \\
Honduras & $0 / 0$ & 2.49 & 18.57 & 124.71 & 92.87 \\
\hline & & $211,614 /$ & $1,101,305 /$ & $3,128,372 /$ & $\mathbf{5 , 3 7 8 , 0 8 2 /}$ \\
Costa Rica & $18,750 / 0.53$ & 5.38 & 25.49 & 66.99 & $\mathbf{1 1 1 . 9 1}$ \\
\hline & & $743,628 /$ & $2,411,753 /$ & $7,700,336 /$ & $8,649,000 /$ \\
El Salvador & $13,475 / 0.23$ & 12.47 & 39.71 & 123.83 & 137.34 \\
\hline & & & $1,119,379 /$ & $3,962,247 /$ & $5,160,966 /$ \\
Nicaragua & $4,400 / 0.09$ & $90,294 / 1.77$ & 20.51 & 68.05 & 86.13 \\
\hline & & $856,831 /$ & $4,510,067 /$ & $18,067,970 /$ & $20,787,080 /$ \\
Guatemala & $29,999 / 0.30$ & 7.64 & 35.57 & 125.98 & 137.81 \\
\hline
\end{tabular}

Source: ITU (2013) World Telecommunications Indicators database 
As William Melody (1995) writes, privatization is not the only solution to the issue of access. In fact, privatization is not even necessary for strong policymaking or for "an increase in competitive market forces" (p. 259). What matters more is separation of management, regulatory, and policymaking functions (ibid.). Costa Rica exemplifies this point extremely well: by 2005 , it had a phone line penetration of 32.14 lines per 100 people. In terms of mobile phone penetration, it kept pace with the rest of Central America with a subscription rate of 111.91 per 100 people in 2012. The Costa Rican case demonstrates that telecommunication services can be expanded without privatization if adequate public service policies are in place.

In fact, it was not until the late 2000s that Costa Rica's Institute of Electricity (ICE) lost its monopoly on telecommunication services as part of a ratification to the Central American Free Trade Agreement (CAFTA). The country held a referendum in 2008 where the "yes" vote won with by a slim margin (Lehoucq, 2012, p. 103). While it resulted in ICE losing the monopoly on services and the sector's liberalization, it did not result in ICE's privatization because, as discussed above, many opposed neoliberal and privatization initiatives (ibid.). Out of this came the country's new regulatory agency, SUTEL, in 2008 through the "Law to Modernize Communication Sector Entities" (Law 8660) (SUTEL, 2008).

In sum, reform initiatives led to the creation of regulatory bodies in all five countries. Most of these were bunched up in an incredibly short span of time between 1995 and 1996, while Costa Rica followed suit over a decade later, as Table 4.5 below shows. These bodies would become important in the following steps of sector restructuring and privatization and liberalization. They also show us that the opening up of telecommunications to private enterprise, the market, and competition is not equivalent to "deregulation", but rather the crafting 
of specific legal and regulatory arrangements that facilitate all three of these aspects of telecoms reform.

Table 4.5: Central American Telecom Regulators and Year of Creation

\begin{tabular}{|l|r|r|}
\hline Country & Regulator & Year Created \\
\hline Costa Rica & SUTEL & 2008 \\
\hline El Salvador & SIGET & 1996 \\
\hline Guatemala & SIT & 1996 \\
\hline Honduras & CONATEL & 1996 \\
\hline Nicaragua & TELCOR & 1995 \\
\hline
\end{tabular}

\subsection{Restructuring}

A second theme that characterized Central American telecom reform is, as Argumedo (2007) writes, the restructuring of state-owned operators. This process involved preparing the state-owned enterprise for privatization — with the idea of generating quick revenues and upgrading telecommunication networks - by creating new enterprises. This consisted of keeping fixed-line and mobile services within one enterprise or separating them.

In El Salvador, this meant splitting ANTEL into two bodies in 1997, "under the guise of breaking the state's monopoly of services" (Argumedo, 2007, p. 16). These bodies were the “Compañía de Telecomunicaciones de El Salvador S. A. de C. V.”, or CTE, which managed fixed-line services, and Intel S.A. which managed cellular and wireless communication services. Both were under the regulatory watch of SIGET. It was also at this time that the Superintendence of Telecommunication was formed, as well as the National Electricity and Telephony Fund (FINET), in 1998. FINET was a precursor to present-day universal service initiatives as it was tasked to promote and expand services to rural areas of the country in the name of national 
development $^{7}$ (p. 17). SIGET approved of an auction framework. Thus, with ANTEL restructured, it was ready to be sold.

Other Central American countries also sought to restructure their enterprises to facilitate reform. For Guatemala, this process began in 1993. The Guatemalan government looked to finance public-benefit programs by selling off "low-utilization and low-performance state assets" including the country's national airline and concessions for cellular services in Comcel, but these initiatives were criticized because they lacked transparency (Rivera, 2008, p. 57; Russell, 1996, p. 46). In 1996, after a 36-year long civil war, the country faced a renewed economic crisis (Bull, 2005, p. 66; Rivera, 2008, p. 58), and President Alvaro Arzu's administration, which was seen as anti-clientelist but market-oriented, proposed to modernize the state in order to create a competitive economy; part of this plan included privatizing its telecommunication infrastructure (Bull, 2005, p. 66; Rivera, 2008, p. 58). As Raventos (1998) writes, "the inclusion of the GUATEL privatization... in the 1997 budget was supposed to signal to the private sector the determination of the administration to restructure the state [in order to initiate] a broad discussion of fiscal issues" (p. 45).

Arzu's administration considered three options: first, the government could keep GUATEL a state enterprise and create policies that would strengthen it. Second, it could sell GUATEL with a five-year period of exclusive concession. Third, it could sell GUATEL without a concession and open up the telecom sector to market competition. The government ultimately opted for the third option as it thought that "a competitive atmosphere would [contribute to] telecommunications services and at low prices" (Rivera, 2008, p. 58). It would do this by 1 ) not

\footnotetext{
${ }^{7}$ This will be further dicussed in Chapter 5 .
} 
granting monopoly rights, by 2) having prices set by the state, and by 3) obligating operators to share networks when required (Decree no. 94-96, Article 22; Bull, 2005, pp. 66-67). However, the third of these points left a large amount of control with dominant players because of Guatel's relaxed oversight - competitors within the market would decide how to share networks on their own terms. Guatel would only intervene if issues should arise (Decree no. 94-96, Article 26; Urizar, 2005, p. 36).

Unlike El Salvador, the Guatemalan government opted not to separate Guatel into two enterprises for fear that it would "hinder attracting investors and... affect the sale price" (ibid.). Similarly, neither did Nicaragua, where it wanted to award the winner of the auction a three-year exclusivity clause which included monopoly rights to national and international telephone services as well "the option to acquire a mobile telephone license" (Rivera, 2008, p. 55). Furthermore, in Guatemala's case, the law created Fondetel (eventually becoming its Universal Service Fund) for the development of telecommunication services in rural areas (Bull, 2005, p. $67)$.

Similarly to Guatemala, Honduras created an enterprise in 1999 called "the Honduran Telephone Company S.A.", or "Honducom", to facilitate the sale of Hondutel. Hondutel's assets would be transferred to Honducom. The transfer process started in 1997 with Honduras seeking the help of a consortium comprised of investment bank N. M. Rothschild, the law firm Squire, Sanders and Dempsey, and the multinational financial institution Price Waterhouse (Tabora, 2007, p. 12). However, Honduras' history of being a country with complicated reform processes would repeat itself throughout this process. As discussed above, Hondutel's restructuring was done to meet conditions of the World Bank's third Structural Adjustment Agreement with the country, introduced in 1995. To meet this requirement, Honduras' congress reviewed two laws: 
the new telecommunication law, and the Law to Restructure Hondutel, which "would facilitate the process of issuing bids for the company" (Bull, 2005, pp. 152-153). Of these two laws, only the former was enacted because of disagreements between political parties and private sector actors over the usefulness of privatization. This meant that "there would be no law to regulate the processes of privatizing the company" (p. 153).

Eventually, in 1999, Honducom was created and received Hondutel's assets. 47 per cent of its shares would be auctioned off, 2 per cent would be sold to workers, and 51 per cent would remain with Hondutel (Rivera, 2008, p. 59). After many delays, particularly ones caused by Hurricane Mitch (Tabora, 2007, p. 13), the bidding process took place in 2000, with seven companies looking to acquire the 47 per cent stake in Honducom. However, this delay made Honduras an unattractive country to invest in; in the eight years leading up to the auction, "few telecommunication engineers were created in Honduras" and the country had only invested US $\$ 12$ million into its infrastructure (Bull, 2005, p. 165). Unlike Nicaragua, reform initiatives in Honduras were proving to be difficult to carry out.

Nicaragua was more vulnerable to telecom reform and privatization compared to other countries because of its massive external debt which it had been unable to control for years leading up to the 1990s. In an effort to shake this debt, the Sandinista government rolled out three austerity measures between 1985 and 1990 (Lehoucq, 2012, p. 104). These initiatives continued into the 1990s under a new, post-revolution government led by Violeta Barrios de Chamorro, which implemented additional austerity measures, including the elimination of 20,000 public sector jobs. The state also sold 351 of its corporations in the process and was left with only three enterprises, one of which was Telcor (ibid.). 
The state introduced a "bonds compensation program" in October 1992 to address the issue of land indemnities. (Herrera, 1996, p. 55; Rivera, 2008, p. 55). Following the creation of the compensation program, a temporary regulatory body was formed called DIGITEL. On January 12, 1994, nine applicants were announced as investors who met the minimal bidding requirements for Telcor (Herrera, 1996, p. 55). All were foreign-owned: AT\&T, Cable \& Wireless, France Telecom, GTE, Korea Telecom, Singapore Telecom, Sprint, Stet, and Telefonica (ibid.). Privatization was underway in Nicaragua.

In Costa Rica, there had been many attempts to reform ICE. Foreign aid played a significant part in Costa Rica's telecommunication services in the late 1970s and throughout the 1980s. In 1978, the World Bank loaned the country US \$10.6 million for a period of five yearsthe fifth of its kind - to expand services and to replace old equipment (World Bank, 1978, p. 1). Moreover, the Costa Rican government signed a loan with the World Bank worth US \$80 million which included a Structural Adjustment Program aimed at "macroeconomic stabilization" through the reduction of fiscal spending (Bull, 2005, p. 97). This affected ICE for three reasons: first, it meant that ICE could not hire any new employees; second, it gave the government improved mechanisms to control spending; and third, it limited public spending on ICE to only 6.4 per cent of its GDP from 1984-1986. As a result, annual increases in telecommunication investments fell from 16 per cent to 4 per cent, and furthermore, ICE cancelled plans to expand its rural telephone network, leaving a waiting list of 11,000 (ibid.). Moreover, because ICE had to work with less revenue than before, telecommunication tariffs were raised (ibid.).

In 1995, with the country facing financial uncertainty, and with Millicom ceasing operations, there were renewed calls for the privatization of ICE; this time, these calls came from 
high levels within ICE, several ministries, and even unions (Raventos, 1998, p. 48; La Nacion, 23 July 1995). However, Roberto Dobles, the President of ICE who was also an industrial engineer with a PhD in business administration, thought that what best-suited Costa Rica's telecommunication services was a "European Model" of privatization instead of the "Latin American" model — that is, "introducing private competition to the state-owned company" rather than selling it "within a framework of limited or no competition" (Bull, 2005, p. 106). Dobles proposed a "triple project" for ICE which included modernizing and strengthening ICE through the "Law of Modernization and Strengthening of the Costa Rican Electricity Institute", and two laws to liberalize telecommunication and electricity services (p. 107). This included transforming ICE into a "100 per cent state-owned company", called Corporation ICE (ibid.). ICE's telecommunication assets would be free to "enter into strategic alliances with private companies" (ibid.). However, the proposal was struck down by the Legislative Assembly as many in the legislature were opposed to any privatization initiatives. Instead, it opted to strengthen ICE without the use of private capital (p. 108).

Thus, through a desire to improve and stabilize national economies and with the intervention of international lending institutions, states created regulatory bodies that would be important for the future of their telecom sectors. With regulatory bodies in place, the countries (with the exception of Costa Rica) were ready to privatize their state-owned enterprises. As the next section will illustrate, this was done by way of auctions, and key players to these auctions were three transnational companies: Telefonica, Millicom, and America Movil.

\subsection{Privatization and Liberalization}

Privatization in Central America followed a larger trend of investments by European and Mexican companies within Latin America. As stated above, this initially resulted in 
unfavourable results in countries such as Argentina and Chile throughout the 1980s as instead of creating greater access to telecommunication services, they hindered its development. One can argue that the privatization process in the region was reminiscent of past colonialist times as European countries, specifically the Spanish company Telefonica, invested heavily into the region (Hills, 2007, p. 170). By 1999, Telefonica had invested US \$11 billion in Latin American countries such as "Argentina, Brazil, Chile, Colombia, El Salvador, Peru, Puerto Rico and Venezuela" (Reuters, 1999). In 2000, Telefonica and Telmex (which was bought by America Movil in 2010) "launched strategies to capture the Latin American [mobile and internet] market" (Becerra and Mastrini, 2012, p. 79). By 2003, Mexican-based America Movil had 36 million wireless subscribers across Latin America (Dow Jones International News, 2003).

Market ownership figures within Central America are difficult to obtain for a few reasons. First, some companies are privately-owned and are unwilling to publish these figures. Second, data provided by Central American telecom regulators are often either outdated or unavailable. Third, prominent companies within the region which do publish these figures in annual reports do so in a way which covers "Central America" as a single region instead of as individual countries. For instance, Telefonica and America Movil have published figures which suggest that the companies operate 20 per cent and 85 per cent of all fixed lines in the region, respectively. They also account for 31.5 and 31 per cent of the wireless market, respectively (Telefonica, 2014; America Movil, 2014) ${ }^{8}$. Additionally, Millicom (another dominant mobile player in the region) has published figures illustrating a high market share in Honduras (65.5 per cent), Guatemala (53.5 per cent), and to a lesser extent, El Salvador (37.8 per cent) (Millicom,

\footnotetext{
${ }^{8}$ Figures are estimates. Telefonica publishes data based on Guatemala, El Salvador, Nicaragua, and Panama. America Movil draws on the region of "Central America and the Caribbean", which includes Panama, Puerto Rico, and the Dominican Republic, in addition to the five countries of this study.
} 
2014). In all, Telefonica, America Movil, and Millicom are the dominant cellular providers in the region. Telefonica operates in four of the five.

Table 4.6: Dominant Telephone Operators in Central America

\begin{tabular}{|l|r|r|r|r|r|r|}
\hline & \multicolumn{2}{|c|}{ Telefonica } & \multicolumn{2}{c|}{ American Movil } & \multicolumn{2}{c|}{ Millicom } \\
\hline & Fixed & \multicolumn{1}{c|}{ Mobile } & Fixed & Mobile & Fixed & \multicolumn{1}{c|}{ Mobile } \\
\hline El Salvador & $\mathrm{x}$ & $\mathrm{x}$ & $\mathrm{x}$ & $\mathrm{x}$ & & $\mathrm{x}$ \\
\hline Nicaragua & $\mathrm{x}$ & $\mathrm{x}$ & $\mathrm{x}$ & $\mathrm{x}$ & & \\
\hline Honduras & & & & $\mathrm{x}$ & & $\mathrm{x}$ \\
\hline Costa Rica & & $\mathrm{x}$ & & $\mathrm{x}$ & & $\mathrm{x}$ \\
\hline Guatemala & $\mathrm{x}$ & $\mathrm{x}$ & & & & \\
\hline
\end{tabular}

Source: SIGET (2013) Boletín Estadístico de Telecomunicaciones Año 2013; SIT (2013) Líneas Móviles por Operador, Telefonía Pública y Comunitaria; Lineas Fijas por Departamento y Municipio, por Operador; Conatel (2013) Registro de Operadores - Operadores del Servicio PCS; Telcor (2013) Participación de Mercado de los Operadores del Servicio de Telefonía Celular por Año; SUTEL (2013) Informe De Labores Costa Rica: 2013

In El Salvador, shares in the country's fixed-line operator, CTE, and the country's mobile operator, Intel S.A, were sold in 1998 to foreign companies in separate auctions, each generating revenues higher than their minimum entrance requirements. For CTE, the minimum bid was set at US \$268.8 million. There were ten foreign companies looking to buy into the fixed-line sector, but ultimately 52 per cent of CTE was sold to France Telecom for $\$ 275$ million. 41 per cent of the company remained with the state; the rest was left with ex-public service employees and minor investors (Argumedo, 2005, p. 22). Intel S.A.'s minimum bid requirement was set at US \$11.9 million and was sold to the Telefonica for US \$41 million (ibid., p. 16).

In the following years, the country's fixed-line telephone landscape would become concentrated. In 2003, France Telecom sold its stake of CTE to America Movil for US $\$ 413$ million (p. 22). American Movil then went on to buy the government's stake in CTE for US \$295 million. This proved to be valuable for American Movil as CTE had assets in internet 
services, long distance calls, and a large revenue stream from fixed-line telephone services. The remainder of CTE was split between Telefonica, Telemovil, and Saltel, with each owning 3.5 per cent, 3.1 per cent, and 1 per cent of the company respectively and completing its privatization (ibid.). By the mid-2000s, other providers entered the fixed-line market, but fixed-lined telephony had become heavily concentrated as the top fixed-line providers of the country were America Movil followed by Telefonica. Telefonica was only able to grow its fixed-line services by bundling internet, cable TV, and fixed-line telephone services (ibid). As of 2013, there are ten fixed-line operators in the country.

In Guatemala, the state intended to sell up 95 per cent of Telgua, valued at US $\$ 440$ million, through SIT, with the help of Citibank (Bull, 2005, p. 67). An auction was held in December 1997 with minimum bids set at US \$10 million; companies intending to enter the auction needed to be strong service providers, with 1.5 million telephone lines already in operation in other markets. This requirement essentially excluded any local investors from the auction but encouraged international investors to enter, including the American companies MCI, Southwestern Bell, and GTE, the Mexican company Telmex, and France Telecom (ibid.). Telmex was the only company to submit a bid (US\$ 563 million), but the committee felt that the bid was too low, so the auction was cancelled (ibid.). Reforms to the bidding process were implemented to include investment groups and banks, and in November of the following year, Telgua sold 95 per cent of its shares to Luca S.A for US $\$ 977$ million (Rivera, 2006, p. 58). Telgua then sold 45 per cent of its remaining shares to Telmex (ibid.). By 2000, Telmex had bought 79 per cent of Luca's stocks and had gained a considerable amount of control over the country's telecommunication landscape (Bull, 2005, p. 69). As of 2013, Guatemala has eight fixed-line providers. 
In Honduras, initiatives were taken in the 2000s to promote sector competition. One of these was the "Telephones for All" initiative ("Telefonos Para Todos", or "TpT") which aimed to produce 200,000 phone lines by the end of 2005 (Tabora, 2007, p. 75). TpT introduced fixedline providers into the sector to operate as "sub operators" (operate using Hondutel's infrastructure) with the possibility of becoming a full operator later on (Tabora, 2007, p. 34). Sub operators were required to "make investments in infrastructure in order to expand the public telecommunications network" (ibid.). Sub operators grew by the tens; by 2005, "forty companies had obtained registration as sub-operator of which 17 had started commercial operations and installed 63,000 telephone lines" (Rivera, 2006, p. 60). However, this did not come close to reaching TpT's goal of creating 200,000 phone lines (p. 75). Auctions did not produce favourable results, either: in 2000, of the seven companies present at Hondutel's auction, only one made an offer (Telmex) and because its bid did not meet Honduras' expectation of US $\$ 372$ million ${ }^{9}$, the auction was cancelled and postponed until 2005. Privatization attempts were repeated in 2005 but to no avail. As of 2013, Hondutel remains state-owned and the country's only fixed-line operator.

As Bull (2005) points out, among the reasons for Hondutel's failure to privatize are the lack of domestic investors, partially due to the World Bank's lack of attention to domestic groups, and the "scarcity of institutions with the necessary expertise that could promote ideas supporting market orientation of the economy" (pp. 165-166). Additionally, the government failed to provide a clear framework for its privatization (Tabora, 2005, p. 14). Indeed, the reform process has been riddled with issues that have affected the countries universal service plans.

\footnotetext{
${ }^{9}$ Telmex’s bid was US \$108 million (Tabora, 2007, p. 13).
} 
In Nicaragua, after various delays, the auction to sell Telcor went ahead on December 21, 2001 with a benchmark price set at US \$203 million. The enterprise was sold to two foreign companies: forty per cent went to the Swedish-Honduran venture, Telia Swedtel Ab-Megatel EMCE for a twenty year period concession. However, the price paid was US $\$ 83$ million, far below the benchmark price (p. 56). The government then sold its 49 per cent ownership to America Movil without a bidding process in 2004. At the same time, America Movil acquired Megatel of Honduras, thus making America Movil the sole shareholder of ENITEL. More recently, in 2006 the country sought help from the World Bank to increase telecommunications access in the country's rural areas. A US $\$ 7$ million loan was approved in 2006 with an initial closing date of 2011 for such purposes. It was later pushed back to March 2015 (World Bank, 2006, 2014).

In addition to fixed line services, mobile phone sectors in the region saw growth in the 2000s with incumbents taking advantage of liberalization. For instance, El Salvador's mobile phone sector was less concentrated than its fixed-line sector, as it grew from one service provider, Millicom, in 1993 to five in 2005 following a series of events:

- Telefonica paid US $\$ 40$ million to enter the mobile market in 1998 (Reuters, 1998);

- CTE Telecom Personal entered in 1999 and was later purchased by America Movil in 2003 for US $\$ 417$ million which gave it 15 per cent of the market (Dow Jones Newswire, 2003);

- Jamaican-based Digicel entered in 2002 and had interconnection agreements with the other operators (Business News America, 2002);

- and finally, Panama-based Intelfon entered in 2005 after paying US \$50 million (El Diario De Hoy, 2005). 
Regulatory liberalization and the development of competition over time helped services grow substantially. From 1995 to 2012, basic penetration levels rose from more than 0.23 lines per 100 people to 137.34 per 100 people, as seen in Table 4.3. By the mid-2000s, Telefonica's and Millicom's presence spilled over to internet services, with both companies becoming the country's dominant internet service providers. Their presence is also felt in the other four countries.

In Guatemala, cellular services started with Telgua and Comcel (later rebranded as "Tigo" by Millicom), the latter being the dominant mobile provider for much of the 1990s. In 1999, Telefonica entered the market as a competitor to Comcel as part of their US $\$ 400$ million dollar investment in the country. Aside from providing mobile services, the investment included long-distance calling and the creation of 3,000 jobs (Reuters, 1999). Telefonica became Comcel's fiercest competitor as 1) it entered into a partnership with Grupo Lodrina, which was already trying to compete with Comcel (Bull, 2005, p.78), and 2) because it was by now an already well-established telephone operator in the region (Funes, 2002, p. 124). Telefonica increased its size in 2004 after it bought out BellSouth's mobile assets in the region (a deal worth US \$5.85) giving it, at the time, a 19.6 per cent share of the country’s mobile market (El Pais, 2004; Urizar, 2005, p. 23).

Shortly after, Comcel was rebranded by Millicom under its "Tigo" brand in 2005 (p. 25; Millicom, 2015). The latest operator to have eyes on Guatemala's mobile market is Digicel, which has expressed interest in being the country's fourth cellular player since 2006, even acquiring an operating license that same year (Sunday Business Post, 2006). However, as of 2013, the company has yet to roll out services. Thus, by 2013, Guatemala's mobile market consisted of Telgua, Telefonica, and Millicom. 
Honduras originally had planned for three mobile service providers in 2002: “(i) Telefónica Celular, S.A. (Celtel); (ii) the winner of the capitalization process of Hondutel; and (iii) the winner of the bidding for Band B, on $800 \mathrm{MHz}$ " (Celtel was operating Band A) (Rivera, 2006, p. 82). However, difficulties surrounding Hondutel's privatization made Celtel the country's only mobile operator in 2002, having been in operation since 1996 (Tabora, 2005, p. 39). Despite being the country's only provider, Honduras' first six years with mobile service saw high annual growth averaging 105.4 per cent. By 2006, Celtel aimed to have 28,180 mobile subscribers, but this goal was reached far more quickly. Indeed, within just two years, Celtel had 29,336 mobile subscribers (ibid). Many of these subscribers were upper class members of the business community. It was only in 1998 when Celtel introduced prepaid phone plans that lowerincome and low-usage citizens and families gained meaningful access to the services. By 2003, prepaid services accounted for almost 82 per cent of all mobile phone subscriptions; this was a trend that was growing within the region (further discussed in chapter 5) (p. 40). In 1998, the government announced plans to license a new mobile operator using the PCS frequency (p. 41).

In 2003, the government enacted the Law of Interconnection, which required mobile operators to share networks, as well as allow Hondutel to enter the mobile market once its exclusivity period for fixed-line telephony expired in 2005 (p. 43). At the same time, an auction was held to sell a license to operate the PCS frequency. Megatel-ECME was the only company to submit a bid, and on April 24, 2003, it acquired the license for US \$7.1 million (ibid.). One year later, Megatel-ECME's assets in the country, including its 61,000 wireless subscribers, was acquired by America Movil (Wall Street Journal, 2004). Millicom also partnered with Celtel in 2004 which it eventually bought out in 2010 (Reuters, 2010). Thus, in 2013, Honduras' mobile phone sector consisted of three operators: Hondutel, America Movil, and Celtel. 
Even after privatization, shadows of Hondutel's corrupt past resurfaced. For instance, in 2009, an FBI investigation uncovered that Hondutel executives were receiving illegal payments from Latin Node Inc., a Florida-based private corporation (FBI, 2009). In 2014, SBWire reported that close ties "between executives at...Hondutel and key members of the government" were common, making it easier for illegal activities to take place.

In Nicaragua, Bellsouth, which was acquired by Telefonica in 2004 dominated mobile phone coverage from 1997 to 2002, largely because it had a monopoly concession for wireless services at the time (Telefonica, 2014; Rivera, 2006, p. 73). Telcor decided to encourage more competition, so in 2001, it held an auction consisting of thirteen different operators. Originally, an operator connected to the country's President (Arnoldo Aleman) won the auction, but accusations of corruption led to the license being forfeited and transferred to the second highest bidder, or PCS SERCOM, an affiliate of America Movil (ibid.). America Movil became the dominant player in the sector after acquiring ENITEL's license in 2004. With two licenses in hand, it was the leading mobile wireless operator in Nicaragua (ibid.). As of 2013, Nicaragua's mobile market is comprised of America Movil and Telefonica.

All but one country privatized the development of mobile wireless services. Costa Rica did not auction off its state-owned operator, ICE, as we saw earlier, and as of 2013, it continues to exist. However, by the mid-1990s, the country's internal debt was mounting (CEPAL, 2015), and there were renewed calls to privatize ICE which was valued at US \$458 million. These were struck down by the legislative assembly because it felt that the proposed privatization process was rushed. Further, it felt that by privatizing ICE, the country would be caving into pressures from international lending institutions (Bull, 2005, pp. 109-110). ICE remained the country's sole fixed-line provider but after CAFTA was ratified in 2008, it undertook a process of 
liberalization that also encouraged foreign investors to enter the country's mobile sector. As a result, in 2011, Telefonica and America Movil began operations. Both had 15-year exclusive rights to frequencies: Telefonica paid a concession fee of $\$ 95$ million for three frequencies while America Movil paid \$75 million for two frequencies (La Nacion, 2011). Millicom also begun operations in the country but as an Internet Service Provider.

As Rivera (2006) outlines, Costa Rica was able to expand services sans privatization for three reasons: first, its publically-owned enterprises such as its telecommunication enterprise and electricity enterprise were credited for bringing the country out of poverty and turning it into "the most developed [country] in the region" (p. 52) Second, through ICE, Costa Rica was able to take its telecommunication and electricity services and expand them "to every corner of the country and [achieve] higher levels of coverage than most Latin American countries"compared to the rest of Latin America, Costa Ricans waited far less for telephone access (ibid.). Third, ICE promoted high levels of competitiveness that "enabled it to participate favourably in the most modern international chains of production" (ibid.).

\subsection{Conclusion}

This chapter demonstrated the development of telecommunication services within El Salvador and Central America by exploring the processes of regulatory reform, restructuring, and privatization. All countries underwent liberalization initiatives. Key to this process was the phasing out of military dictatorships, the introduction of democratic reforms, and the influence of international lending institutions such as the World Bank and the IMF in sector reforms. Two countries, Honduras and Costa Rica, experimented or underwent privatization, the former having only privatized its mobile enterprise. Costa Rica maintains ownership on fixed-line telephony through ICE and Honduras did through Hondutel. 
Most countries (all except Costa Rica) created new telecommunication regulators in the mid-1990s, although did so in a rushed manner, privatizing and liberalising in a short time-span from one another. True to form, Costa Rica only did so much later in 2008 and only after the country ratified CAFTA, and even then, it only did so to its mobile sector. As most democratic countries sought to dig their countries out of outstanding debts and economic hardships, governments rushed to open their telecommunication sectors to foreign investment; first to American-owned companies. Once these investments started to taper off, however, European and Mexican companies, particularly Telefonica, Millicom, and America Movil would become the region's dominant service providers. This consequently helped the development and proliferation fixed-line and wireless telephony across the region. Through sector privatization and liberalization, most countries offered a possible solution to the digital divide through privatization. However, the degree of privatization and liberalizations successes in addressing the divide remained to be seen.

Thus, the following chapter will discuss the degree to which the countries have been successful in addressing the issue of access to communication services. It will specifically analyze access to fixed-line telephone services, wireless telephone services, and internet, as well as how successful universal service initiatives have been in addressing these services. 


\section{Spreading the Message: Universal Service Funds and Communication Services}

Liberalization and Privatization swept through Central America in the late 1990s. With new competitors in the fixed-line, mobile, and broadband sectors, most networks were updated and it was assumed that access to these networks would expand. Indeed, the benefits were perceived as two-fold: economically, countries could take advantage of privatization by generating quick revenues. On a social level, service uptake meant that citizens could better engage with new ICTs which were becoming increasingly prevalent in day-to-day social, political, and professional endeavours. To ensure that the second benefit, however, the state needed to exercise its regulatory power to ensure that market competition would not prioritize profits over public service needs.

This chapter explores how universal service policies have developed alongside liberalization reforms in Central America from the year 1996 up to 2013. This timeline encompasses the period right after countries in the region adopted significant telecom reforms until the last year for which complete data sets are available. Additionally, this chapter explores how El Salvador, in particular, has addressed the issue of access and consequently, the digital divide. It will do this in three parts. First, the chapter will lay out the policies that have created universal service funds in each country. In doing so, it will cover the goals set out in each fund, how each fund is financed, and will discuss recent disbursals.

Second, drawing primarily on historical data from the ITU, this chapter explores the degree to which universal service funds have been successful in addressing the digital divide. As this chapter shows, countries' successes vary in addressing the issue with regards to fixed-line, 
mobile, and internet services. The reason for drawing primarily on the ITU is that the organization provides consistent, reliable data. Some Central American regulators and funds have released vague annual reports or have outdated websites; in one case, one universal service fund's website had been hacked in late 2014 and did not come back online until early May 2015. I draw on the policies themselves and base my analysis on the work of Jeffery James (2003), who argues that universal services should encompass telephone and internet access (pp. 112-117) to analyze how policies have affected fixed-line, mobile, and internet service uptake.

Third, based on my findings, I discuss how El Salvador has fared among the countries in addressing these issues over time. I conclude the chapter by summarizing my findings.

\subsection{Universal Service Policies}

Universal service policies aim to "provide service to all" (Hudson, 1997, p. 67). As stated in the introduction of this thesis, these are generally carried out in two ways: either through universal service initiatives or through universal access initiatives. The difference between the two initiatives is seemingly small but fundamental: as stated in the introduction of this thesis, universal service initiatives aim to provide services to every household (Xavier, 2008) while universal access initiatives "seek to guarantee access to telecommunications infrastructure, sometimes on a shared basis" (Stern and Townsend, 2007, p. 21). The latter can be achieved through promoting public services, such as public payphones or telecentres.

Latin American universal service policies were established for the first time in the mid1990s (Hudson, 2010). Two of the five countries covered by this study created universal service funds by the end of 1999; by 2008, four of the five countries of this study had adopted a universal service policy. Another point worth observing is that the emergence of these universal 
service policies did not always coincide with the creation of their regulatory bodies. Of the four countries with policies, two were developed as part or reformed telecommunication laws (Guatemala and Costa Rica) and two were created under separate laws. El Salvador's universal service fund was created in 1998, two years after it had developed its national regulatory body, SIGET. Nicaragua, a historically late investor into telecommunication services, waited nine years after the creation of its regulatory body to implement a universal service fund in 2003 . Costa Rica's universal service fund, FONATEL, was created the same year as its regulator in 2008. Table 5.1 shows that, as of 2013 (and following its history of regulatory hurdles), Honduras is the only country to have not implemented a universal service policy, although it did unveil its failed "Telephones for All" (TpT) project in the mid-2000s, as discussed in chapter 4.

Table 5.1: Creation of Universal Service Funds and Regulatory Bodies (Year)

\begin{tabular}{|l|l|r|r|}
\hline Country & Universal Service Fund & Year Created & Creation of Regulatory body \\
\hline Guatemala & FONDETEL & 1996 & 1996 \\
\hline El Salvador & FINET & 1998 & 1996 \\
\hline Nicaragua & FITEL & 2004 & 1995 \\
\hline Costa Rica & FONATEL & 2008 & 2008 \\
\hline Honduras & None & None & 1996 \\
\hline
\end{tabular}

Source: ITU Country Profiles (2013)

As Martin Hilbert (2011) writes, there is no "one size fits all" solution to the digital divide, and the same could be said about models for universal service policies. Scholars such as Heather Hudson (2010) argue that, just as ICTs and telecommunication landscapes evolve, so too should policies so that they reflect and address newer technologies such as broadband internet and mobile phones. Furthermore, the timing of policy implementation plays heavily into how successful a policy will be in meeting its objectives. Casanueva-Reguart (2013) and Manzetti (2000, p.100) highlight the challenges policymakers face when implementing policies after 
sector privatization and liberalization. They argue that policies implemented after sector liberalization are more susceptible to "regulatory capture".

While universal service funds may bring promises of wider service distribution in Central America, Stern and Townsend (2007) write that "the functioning of most of these funds have been far from perfect" (p. 10). As previous chapters have discussed, this is a problem which dates back to before reforms took hold, as governments have often used funds as tools to raise revenues for the state/treasury in general rather than focusing solely on network development issues, such as the need to update and extend the infrastructure. Funds have often come up short in reaching their goals. According to Stern and Townsend, this is because "[A] major problem with most $[\ldots]$ has been their inability to effectively disburse money collected to finance universal access projects" (ibid.). In some cases, this has meant a wait period of four to five years to finance a country's first universal access project (ibid.). These problems have for the most part carried over into the region's post-reform years in spite of the promises that privatization and liberalization would result in improved services. Furthermore, they identify five shortcomings or pitfalls that have compromised the ability of universal service funds to meet their objectives:

the first is political and results from governments' either failing to pass enabling legislation or holding back approvals for funds to be spent or failing to put into place a mechanism for collecting and disbursing fund[.] Secondly, there is the considerable amount of time required to elaborate, evaluate and implement projects to be financed out of these funds[.] Thirdly, since these projects are often considered by governments to be public investments they are subject to the same lengthy and bureaucratic approval process as any other project funded from public funds[.] Fourthly, the regulator does not 
attach high priority to universal access[.] Fifthly, disbursements from universal access funds may be subject to additional constraints established by outside institutions such as the International Monetary Fund (pp. 10-11).

Central American countries reflect these findings. However, some have been better at dispersing funds than others. For instance, Table 5.2 shows that by 2005, almost a decade after the region's first universal service fund was created, the only country which had disbursed any funds over US \$1 million was Guatemala. Costa Rica on the other hand disbursed more than US $\$ 31$ million in its first five years of its existence. It should come as no surprise that El Salvador's fund has not contributed to any telecommunication projects because, as this chapter will discuss, virtually no funding is allocated to telecommunication projects.

Table 5.2: Total amounts collected and disbursed (USD)

\begin{tabular}{|c|c|c|c|c|c|}
\hline Country & Fund & \begin{tabular}{|l|} 
Year \\
Started
\end{tabular} & \multicolumn{2}{|c|}{$\begin{array}{c}\text { Amounts Collected and disbursed by } \\
\mathbf{2 0 0 5}^{10}\end{array}$} & $\begin{array}{l}\text { Rate } \\
\%\end{array}$ \\
\hline \multirow[t]{2}{*}{ Guatemala } & FONDETEL & 1996 & Collected & $\$ 17,943,154$ & \multirow{2}{*}{$43 \%$} \\
\hline & & & Disbursed & $\$ 7,756,518$ & \\
\hline \multirow[t]{2}{*}{ Costa Rica } & FONATEL & 2008 & Collected & $\$ 222,865,945$ & \multirow{2}{*}{$14 \%$} \\
\hline & & & Disbursed & $\$ 31,212,876$ & \\
\hline \multirow[t]{2}{*}{ Nicaragua } & FITEL & 2004 & Collected & $\$ 3,278,559$ & \multirow{2}{*}{$12 \%$} \\
\hline & & & Disbursed & $\$ 400000$ & \\
\hline \multirow[t]{2}{*}{ El Salvador } & FINET & 1998 & Collected & $\$ 32,701,810$ & \multirow{2}{*}{$0 \%$} \\
\hline & & & Disbursed & $\$ 0$ & \\
\hline
\end{tabular}

Source: Stern and Townsend (2006, Table V1.7); World Bank (2006a); SUTEL (2013)

Because policy implementation and goals differ between Central American countries, countries can be categorized into three groups: the first, consisting of one country which has not created a universal service policy, is Honduras. While Honduras did not implement a universal

\footnotetext{
${ }^{10}$ Figures for Costa Rica are based on 2013 data. They were included in this chart to illustrate the country's effectiveness in disbursing funds when compared to other countries.
} 
service policy or fund, it did implement its TpT plan throughout the 2000s, as discussed in chapter 4 . This project aimed to create 200,000 fixed-lines by the end of 2005 through sector competition. However, Honduras fell far short of its goal. Indeed, by the end of 2005, only 63,000 lines had been created.

The second group consists of countries which have created poorly managed universal service policies: El Salvador, Guatemala, and Nicaragua. The third group consists of one country that has created policies that have been a moderate success: Costa Rica. The following section will discuss the latter two groups.

\subsubsection{Poorly Managed Policies}

El Salvador created its universal service fund, FINET, in 1998 under Decree no. $354^{11}$, with the intention of not only addressing the issue of access to telecommunication services, and access to electricity services as well. This approach was taken because the government saw both telecommunication and electricity as key infrastructures for the social and economic development of the country. To this end, it promoted both services under one fund. FINET's mandate of ensuring "the widest possible service distribution across the country, especially in rural and low-income areas" included promoting electricity and telephony as economic and social drivers, as essential to state welfare, and essential for "economic order" (Decree no. 354, 1998, “Considerando").

Because FINET tackles the larger issue of socio-economic development beyond just telecommunications, it is not managed by SIGET, but by another government body, El Salvador's Social Investment Fund for Local Development (FISDL) (Article 1). Among other

\footnotetext{
${ }^{11}$ Decree no. 354 was last revised in 2004
} 
developmental initiatives that FISDL oversees are water services, emergency funds, and rural development initiatives - in other words, the basic infrastructure of the country (FISDL, 2014). This contrasts with Nicaragua, Guatemala, and Costa Rica's approach to universal service, all of which manage their policies through their telecom regulators. Of course, this thesis does not and cannot cover all of these areas, and since its focus is on telecommunications, that is the aspect of FINET that will be focused on in the following pages.

FISDL oversees FINET with the goal of spreading telephone services to rural and poorer areas of the country (Decree 354, 1999, Article 1, 3). To meet this objective, FISDL was created to subsidize telephone infrastructure, including communal telephone services, to the country's rural and lower-income areas (Article 4). Funds were intended to be distributed on a case-bycase basis; applicants would have to submit a proposal which would identify the case in question's social benefits and estimated costs (Article 10). Additionally, financial support would come from FANTEL, a fund created by revenues generated from the sale of ANTEL, to finance telecentres (Stern and Townsend, 2006, p. 47). At minimum, FINET's goal is to fund the availability of fixed-line public payphones in all rural and low-income areas of El Salvador.

However, as mentioned above, telecommunication projects have not received any funding from FINET. Instead, El Salvador has opted to rely on market competition over policies to address the issue of access to telecommunication services:

FINET's priorities are clearly to address the continuing unsatisfied demand for electricity, especially in rural areas. FINET believes that the demand for telephone services is being met by the private sector, and that there is no need to subsidize projects in this sector (source p. 99). 
Whether or not this approach has worked for El Salvador will be discussed later in this chapter. Other countries have, however, chosen to manage their universal services through their telecom regulators, but as Table 5.2 has shown, this has not always produced results. An analysis of the other countries' universal service funds reveals that management by the telecom regulator alone does not result in realized goals. Guatemala and Nicaragua have faced this reality.

Like El Salvador, Nicaragua introduced its universal service policy years after it had enacted its telecommunications law. In 2003, the country introduced Decree no. 84 (which it enacted in June 2004) to create its universal service fund, FITEL. FITEL complemented the 1996 Law of Postal Services and Communication which opened the sector to private competition and gave TELCOR authority to oversee the sector's operations (Article 7). Embedded in the policy were responsibilities to promote "universal services", regardless of geographic location, to promote private competition, social and economic development, public consultations, and to meet goals set out in the country's telecommunication law (Article 3). On the other hand, Guatemala's Universal Service Fund, FONDETEL, was created as part of its 1996 telecommunication law (Decree 94-96, 1996). Unlike El Salvador and Nicaragua which use universal service funds to pursue many detailed objectives, FONDETEL has only one goal: to act as "a financial administrator to promote and develop telephone services in rural areas and/or low-income areas" (Article 72).

The way in which funds are disbursed also varies depending on the country. In Nicaragua, loose language gave FITEL a degree of flexibility with respect to allocating the funds at its disposal, as Article 12 of Decree no. 84 identified "telecommunication projects, ICTs, and postal services" as areas eligible to receive FITEL funds. First, this meant that, funds could be used towards network investment, operation assistance, and maintenance. Moreover, it could 
provide "support services" in these areas, such as the undertaking of studies to improve services (Article 12). Second, newer telecommunication services such as internet access could be financed years down the road, but were not addressed at the outset. To maximize service distribution, FITEL also allocated resources to "annual projects": public telephone networks, call centres, telecentres, and "any other communication service that would directly benefit" the community pertaining to the targeted project (Article 16). Its goal was ultimately to extend cellular coverage and to "ensure all rural communities with populations greater than 400 inhabitants have at least one public payphone and all municipal heads have access to the internet at affordable rates” (World Bank, 2006, “FITEL's First and Second Rural Projects”).

Guatemala, on the other hand, followed a more "Salvadorian" distribution model. Fund allocation was left to a case-by-case basis where service providers proposed the economic and technical details and social benefits of their projects (Decree 94-96, 1996, Article 73). The Ministry of Communications, Transport, and Public Affairs then evaluated the proposal, giving priority to projects which had the "highest rate of social and private return" (ibid).

The second part of universal service policies that affects operations is how they are financed. Generally speaking, universal service funds are comprised of the proceeds from spectrum and auction concessions, sector fines, and sector taxes (i.e. contributions by operators) (Stern and Townsend, 2007, Table 1). All three countries have adopted this approach; for instance, El Salvador's FINET receives concessions comprised of 98.5 per cent of spectrum auction sales and concessions collected from any contracts and licenses established prior to the enactment of El Salvador's Telecommunication law (Decree 354, Article 13). No more than one per cent of the fund can be used to cover FINETs administration costs (ibid). For Guatemala's FONDETEL's first seven years of existence, it received concessions comprised of seventy 
percent of revenues generated by auctions, for a maximum of thirty million quetzals per year (Decree 115-97, Article 72). Nicaragua received concessions from licensing fees, spectrum fees, and fees incurred by TELCOR (Decree no. 84, Article 8). Additionally, all three countries receive funds from sector fines.

The similarities in how Nicaragua and Guatemala's funds are financed go even further. For instance, both receive funding from the state. Furthermore, both policies permit loans and donations from outside sources, including international lending institutions (Decree no. 84, Article 8; Decree 115-97, 1996, Article 72). This has been important for the years after liberalization because both countries have continued to seek help from the World Bank in the 2000s.

For instance, by 2005, Guatemala’s FONDETEL had disbursed almost US $\$ 8$ million on infrastructure development. FONDETEL's disbursals went toward “pay and residential telephones in nearly 2000 population centres" (Stern and Townsend, 2007, p. 87). However, this accounted for less than half of the fund's total and, moreover, very few of these telephonesabout twenty per cent—actually worked. As Stern and Townsend point out, "this is because of inadequate planning and structuring of projects, poor timing of subsidy flows and, above all, the complete lack of any kind of supervision" over the project (ibid.). Guatemala sought to fix this in 2006 with the help from the World Bank as part of a much larger loan to assist in national development projects (World Bank, 2006b). The ten-year project allocated funds to assist in infrastructural development in select areas of the country. The aim, of course, was to further extend telephone services as well as increase broadband internet connections in rural areas (p. 38). The World Bank indicated that the project would increase telephone access, either fixed-line or mobile, by thirty per cent in rural areas, and by approximately 3.5 million people in the entire 
country (p. 47). Internet access would consist of telecentres that offered access to a minimum of five computers in one hundred municipalities (ibid.). In all, the plan seeks to bring 5,234 public pay phones, 18,285 private lines, and 288 internet centres to people across the country at a total cost of US \$25.7 million (pp. 38-39).

In Nicaragua, TELCOR undertook its first universal service project in 2005, “The Rural Telecommunications Project", a project which the government considered to be a "high priority" (World Bank, 2006, p. 1). Its aim was to increase cellular coverage, increase the number of public payphones, and increase internet accesses in rural areas, a project that required $\$ 400,000$ of FITEL funding (p. 5). TELCOR awarded the funding to ENITEL with the expectation of tripling the number of payphones, benefitting over 256,000 people in 366 Central and Pacific communities, as well as increasing cellular coverage to 67,000 people (ibid.). The project was completed in 2006 with mixed, results: the country's total amount of payphones saw an insignificant increase in density per 100 people from 1.2 in 2005 to 1.6 in 2006 (ITU, 2014a). However, mobile phone services saw some growth, with penetration rates jumping from 20.5 per 100 in 2005 to 33.1 per 100 in 2006.

TELCOR's second project was also carried out with funds from FITEL as well as a loan from the World Bank and aimed "to ensure all rural communities with populations greater than 400 inhabitants have at least one public payphone and all municipal heads have access to the internet at affordable rates" (ibid.). The project was expected to be complete in June 2006; however, the World Bank ended up extending the deadline to March 31, 2015 and adding US \$5 million to the original loan (World Bank, 2012, p. 6). 


\subsubsection{Costa Rica: Universal Service with Moderate Successes}

Of the countries which have introduced universal service policies, only one has been successful, albeit moderately, at meeting its goals: Costa Rica. Because Costa Rica underwent telecom reform years after the other countries, it was able to learn from the shortcomings of other countries' policies. Costa Rica created FONATEL in its telecommunication law, Decree no. 8642 (2008), as "an instrument to manage resources to finance universal access, universal service, and any related objectives" established within the law (Article 34). SUTEL was put in charge of FONATEL. It created goals which not only emphasized basic access to telecommunication services, but access to quality telecommunication services. In addition to promoting infrastructure development, it aimed to promote access to affordable, quality telecommunication services to under-served social groups (such as "Indigenous persons") and to public institutions (Article 32). It also aimed to reduce the digital divide by increasing access to broadband services (ibid.).

Costa Rica's FONATEL is funded by concessions, donations from private or public institutions, fines and interests imposed by SUTEL, and any revenues generated by FONATEL on its own. Additionally, FONATEL collects taxes from telecommunication operators and providers, the amount of which is determined by SUTEL on a yearly basis and ranges between 1.5 percent and three per cent of the provider's gross revenue (Article 38, Article 39). Like El Salvador's FINET, FONATEL ensures that funds are primarily used to improving services by capping the amount that can be used for FONATEL's administrative uses - only one per cent (Article 38). Moreover, FONATEL is kept under tight management as it is subject to a yearly external audit (Article 40). 
Costa Rica's universal service projects stand in sharp contrast to the slow growth observed in the other three countries, a fact that reflects the country's ability at implementing policies. During FONATEL's initial years, it too was slow to disperse funds-in 2012, the fund contributed US $\$ 600,936$ to universal service initiatives. However, fund disbursal ballooned to $\$ 30,611,940$, in 2013 and doubled again in 2014 to $\$ 60,967,307$ (SUTEL, 2014, p. 31). FONATEL's first disbursal of funds was to Telefonica in 2013 which aimed to provide internet and phone services to "more than 4,000 people and 1,200 students from nine schools and two local colleges" in the Limon province of the country. These recipients had been waiting for services for over ten years (La Nacion, 2013; SUTEL, 2013). Additionally, SUTEL announced that it would hold similar auctions to service six municipalities within the Limon provinces, and would allocate US $\$ 26.7$ million to service a total of 200,000 people (SUTEL, 2013).

In sum, the countries discussed in this chapter can be categorized into three groups: one which does not have a universal services policy, those which do but have not seen much success, and one which has implemented initiatives and has seen moderate success. As Table 5.3 summarizes, as of 2013, only Nicaragua has targeted all three areas of fixed-line telephony, mobile telephony, and internet services. El Salvador, the main focus of this thesis, has a universal service fund but allocates any revenues generated by spectrum auctions to service electricity initiatives. Two of the countries which do carry out universal service initiatives do so with loans from the World Bank - a pattern which has carried over from the pre-reform days.

Table 5.3: Universal Service Fund Targets

\begin{tabular}{|l|l|l|l|}
\hline & Fixed line & Mobile Phone & Broadband \\
\hline Guatemala & $\mathrm{x}$ & $\mathrm{x}$ & $\mathrm{x}$ \\
\hline Nicaragua & $\mathrm{x}$ & & $\mathrm{x}$ \\
\hline Costa Rica & & $\mathrm{x}$ \\
\hline
\end{tabular}


The next sections draws on data from the ITU to evaluate how these universal service funds have performed in relation to their primary objective, namely increasing people's access to telecommunications and internet services. Additionally, it will address the degree that privatization and liberalization efforts have been successful in spreading services.

\subsection{Funds and Figures}

Generally speaking, aside from mobile phone penetration, telecommunication penetration levels have lacked in the region, even after privatization and liberalization initiatives were undertaken in the middle to late 1990s. There is a variation between the successes of countries which have undertaken these initiatives, with some, particularly Costa Rica and El Salvador, performing better than others. However, even with newer services such as internet access and mobile telephony being introduced and developed in the region, and even after universal service policies have been created, there remains for the most part the issue of the access divide which had existed before telecommunication reforms.

For instance, the region continues to lack fixed-line telephone penetration in the postreform era. As Table 5.4 shows, Costa Rica has the highest telephone density with 20.7 subscriptions per 100 people in 2012. When compared to developed countries, it is evident that this figure is relatively low: in 2012, for example, Canada had a penetration rate of 50.65 phone lines per 100 and the US had 44.4 phone lines per 100 (ITU, 2013).

Table 5.4: Fixed Telephone Subscriptions per 100 People

\begin{tabular}{|l|r|r|r|r|r|r|r|r|r|}
\hline Country & $\mathbf{1 9 9 6}$ & $\mathbf{1 9 9 8}$ & $\mathbf{2 0 0 0}$ & $\mathbf{2 0 0 2}$ & $\mathbf{2 0 0 4}$ & $\mathbf{2 0 0 6}$ & $\mathbf{2 0 0 8}$ & $\mathbf{2 0 1 0}$ & $\mathbf{2 0 1 2}$ \\
\hline Costa Rica & 14.7 & 19.8 & 22.9 & 25.3 & 31.6 & 30.3 & 31.7 & 22.7 & 20.7 \\
\hline El Salvador & 5.6 & 6.5 & 10.5 & 11.1 & 14.7 & 17 & 17.5 & 16.1 & 16.8 \\
\hline Guatemala & 3.3 & 4.8 & 6 & 7.2 & 9.2 & 10.4 & 10.6 & 10.4 & 11.6 \\
\hline Honduras & 3.3 & 4.2 & 4.8 & 5 & 5.7 & 10.2 & 11.3 & 8.8 & 7.7 \\
\hline
\end{tabular}




\begin{tabular}{|l|r|r|r|r|r|r|r|r|r|} 
Nicaragua & 2.3 & 2.9 & 3.2 & 3.3 & 4 & 4.5 & 4.5 & 4.4 & 5 \\
\hline
\end{tabular}

Source: ITU (2014A) World Telecommunications Indicators Database

El Salvador has opted to rely on private competition over FINET funds for service distribution. As seen in chapter 4, this has resulted in market concentration with America Movil and Telefonica being the country's dominant players. However, it has fared well when compared to the other countries. By 2012, fixed-line density had more than tripled since telecom reform began, and it also had the second highest fixed-line density among countries at a rate of 16.8. In comparison, Honduras, which has only one fixed-line provider (Hondutel) and no universal service fund at all, saw very little growth throughout its TpT project, circa 2000-2005, but its fixed-line density peaked at 10.6 per 100 in 2006. Penetration rates in Guatemala have been steadily climbing since 1996 while Nicaragua has consistently had the lowest telephone density, with a density of only five per 100 in 2012.

Similar trends can be seen in public payphones per 1000 people. Figures for the total number of public payphones are consistent only until 2008. As Table 5.5 below illustrates, these figures show low penetration rates for all countries. However, on a regional level, it shows that throughout the 2000s, Costa Rica and El Salvador have consistently been the countries with the highest levels of public telephone availability among the group of five. The last recorded figure for El Salvador was a density of 0.28 per 1000 in 2009 (ITU, 2014), a dip that this thesis attributes to the rise in mobile phone usage. Costa Rica's also dropped in 2009 to 4.78 payphones per 1000, but this figure is expected to rise once Costa Rica's current project (discussed above) to service the Limon province is complete. Guatemala, which implemented its universal service fund at the outset of telecom reform, and which had funded telephone projects in the early 2000s using FONDETEL, fared better than Nicaragua, which was the last to 
implement its fund. For Honduras, the lackluster results from $\mathrm{TpT}$ are yet more evidence that it has lagged far behind other countries in the region, peaking at just 0.7 public payphones per 1000 people. In sum, despite promises for drastic service improvements, privatization and liberalization have not brought dramatic increases the number of public payphones or fixed-lines in the region, nor have universal service funds.

Table 5.5: Public Payphones per 1000 people

\begin{tabular}{|l|r|r|r|r|r|r|r|}
\hline Country & $\mathbf{1 9 9 6}$ & $\mathbf{1 9 9 8}$ & $\mathbf{2 0 0 0}$ & $\mathbf{2 0 0 2}$ & $\mathbf{2 0 0 4}$ & $\mathbf{2 0 0 6}$ & $\mathbf{2 0 0 8}$ \\
\hline Costa Rica & 2.1 & 2.6 & 3.5 & 5.4 & 5.1 & 4.7 & 5 \\
\hline Guatemala & N/A & N/A & 2.7 & 3.2 & 3.2 & 3.6 & 3.5 \\
\hline El Salvador & 0.9 & 0.8 & 3.7 & 3.6 & 3.8 & N/A & 2.2 \\
\hline Nicaragua & 0.3 & 0.4 & 0.6 & 0.6 & 1.2 & 1.6 & N/A \\
\hline Honduras & 0.2 & 0.4 & 0.36 & 0.5 & 0.7 & 0.8 & N/A \\
\hline
\end{tabular}

Source: ITU (2014A) World Telecommunications Indicators Database

While the figures for fixed-line and public payphone densities differ drastically across the countries, figures for mobile phone penetration are rather similar with respect to at least three of the countries being examined here - El Salvador, Guatemala and Costa Rica - while Nicaragua and Honduras continue to fair relatively poorly. Generally speaking, though, mobile phone use has seen a significant growth in the last fifteen years in part because of prepaid service plans.

Prepaid services appeal to lower-income costumers as they are not bound to long-term contracts. As Table 5.6 shows, these services rose in all countries between 2003 and 2012. In Nicaragua, Honduras, and Guatemala, this meant that by 2012, more than 90 per cent of mobile phone services consisted of prepaid plans. El Salvador's overall number of prepaid plans saw a small decrease from 90 per cent in 2009 to 87.4 per cent in 2012. SIGET reports that the remaining 12.5 per cent of mobile phone services are postpaid; this figure consisted of 713,568 plans in 2007 and rose to 927,287 in 2012 only to drop in 2013 to 785,289 (SIGET, 2013). 
Therefore, mobile telephony's popularity in the country is a reflection of the income divide which persists throughout the region.

Table 5.6: Percentage of Mobile Services that are Prepaid

\begin{tabular}{|l|r|r|r|r|r|r|}
\hline Country & $\mathbf{2 0 0 3}$ & $\mathbf{2 0 0 5}$ & $\mathbf{2 0 0 7}$ & $\mathbf{2 0 0 9}$ & $\mathbf{2 0 1 1}$ & $\mathbf{2 0 1 2}$ \\
\hline Guatemala & 80.6 & 91 & 93.5 & 94.8 & 95 & 95.2 \\
\hline Honduras & 81.3 & 92.4 & 95.8 & 96.6 & 94 & 93.3 \\
\hline Nicaragua & 87.3 & 89.7 & 93.8 & 94.4 & 93.5 & 92 \\
\hline El Salvador & 72 & 64.4 & 89.8 & 90 & 89.5 & 87.4 \\
\hline Costa Rica & 0 & 0 & 0 & 0 & 69.6 & 78.9 \\
\hline
\end{tabular}

Source: ITU (2014A) World Telecommunications Indicators Database; SIGET (2013) Boletín Estadístico de Telecomunicaciones Año 2013.

As Table 5.7 below shows, three of the five countries have mobile phone penetrations of over 100 mobile phones per 100 people. This shows that the heavy presence of Telefonica, America Movil, and Telmex have influenced service distribution in the region in the post-reform era as they have been able to tailor mobile services to the poorer segments of the populations. For instance, in El Salvador, penetration rates grew from 0 mobile phones per 100 in 1996 to over 137.3 phone lines per 100 in 2012 . Guatemala shows very similar results; it did not allocate any FONDETEL funds towards mobile telephony, instead relying on market competition for results.

Costa Rica's phone density ballooned shortly after its mobile phone sector was liberalized between 2010 and 2012, with mobile phone density increasing by 44.9 mobile phones per 100 people in just two years. Nicaragua saw considerable growth between 2004 and 2006, coinciding with TELCOR's first universal service project which increased internet access and the number of public payphones; however, it has the lowest mobile phone density in the region. This is attributed to the lack of market competition within the sector-as seen in chapter 4 , it is comprised of only two providers: Telefonica and America Movil. Honduras had the lowest 
mobile phone density of all the countries in 1996. This figure grew considerably after 2004 when America Movil acquired Megatel-EMCE's assets in the country. In 2010, it had the second highest density with 124.7 phones per 100 people, second only to Guatemala, before falling to 92.9 in 2012.

Table 5.7: Mobile Phones per 100 people

\begin{tabular}{|l|r|r|r|r|r|r|r|r|r|}
\hline Country & $\mathbf{1 9 9 6}$ & $\mathbf{1 9 9 8}$ & $\mathbf{2 0 0 0}$ & $\mathbf{2 0 0 2}$ & $\mathbf{2 0 0 4}$ & $\mathbf{2 0 0 6}$ & $\mathbf{2 0 0 8}$ & $\mathbf{2 0 1 0}$ & $\mathbf{2 0 1 2}$ \\
\hline El Salvador & 0.4 & 2.3 & 12.5 & 14.79 & 30.3 & 63.2 & 113 & 123.8 & 137.3 \\
\hline Guatemala & 0.4 & 1 & 7.6 & 13.4 & 25.6 & 55.2 & 109.5 & 126 & 137.8 \\
\hline Costa Rica & 1.3 & 3 & 5.4 & 12.2 & 21.7 & 32.9 & 41.6 & 67 & 111.9 \\
\hline Honduras & 0 & 0.6 & 2.5 & 5.02 & 10.5 & 31.8 & 84.8 & 124.7 & 92.9 \\
\hline Nicaragua & 0 & 0.4 & 1.8 & 4.52 & 13.7 & 33.1 & 54.8 & 68 & 86.1 \\
\hline
\end{tabular}

Source: ITU (2014A) World Telecommunications Indicators Database

Turning our attention to the issue of internet access, we can see in Table 5.8 below that sector reforms have affected internet use in some countries more than others. Generally speaking, internet use has grown every year from 2002 to 2012 in all countries. In 2012, almost half of Costa Rica's population was using the internet, up from 19.9 per cent in 2002. In El Salvador, this amounted to a quarter of its population using services in 2012, up from 1.9 per cent in 2002. The remaining three countries saw growths as well, although not as significant as El Salvador's or Costa Rica's: by 2012, population internet use from neither Honduras, Guatemala, nor Nicaragua had reached twenty per cent.

Table 5.8: Percentage of Individuals using the Internet

\begin{tabular}{|l|r|r|r|r|r|r|}
\hline Country & $\mathbf{2 0 0 2}$ & $\mathbf{2 0 0 4}$ & $\mathbf{2 0 0 6}$ & $\mathbf{2 0 0 8}$ & $\mathbf{2 0 1 0}$ & $\mathbf{2 0 1 2}$ \\
\hline Costa Rica & 19.9 & 20.8 & 25.1 & 32.3 & 36.5 & 47.5 \\
\hline El Salvador & 1.9 & 3.2 & 5.5 & 10.1 & 15.9 & 25.5 \\
\hline Honduras & 2.6 & 5.6 & 7.8 & 9.6 & 11.1 & 18.1 \\
\hline Guatemala & 3.4 & 5.1 & 6.5 & 8.3 & 10.5 & 16 \\
\hline
\end{tabular}




\begin{tabular}{|l|r|r|r|r|r|r|} 
Nicaragua & 1.7 & 2.3 & 2.8 & 5.3 & 10 & 13.5 \\
\hline
\end{tabular}

Source: ITU (2014A) World Telecommunications Indicators Database

While internet use has grown in the region, these growth rates are not all that impressive relative to international standards. Indeed, they are considerably smaller than those of developed countries - for instance, in Canada, 86.75 per cent of its population were internet users in 83 percent of households in 2012 (ITU, 2014a). The only Central American country to come anywhere close to this figure is Costa Rica. Table 5.9 below illustrates the points with respect to internet access penetration in Central America.

Table 5.9: Percentage of Households with Internet

\begin{tabular}{|l|r|r|r|r|r|r|}
\hline Country & $\mathbf{2 0 0 2}$ & $\mathbf{2 0 0 4}$ & $\mathbf{2 0 0 6}$ & $\mathbf{2 0 0 8}$ & $\mathbf{2 0 1 0}$ & $\mathbf{2 0 1 2}$ \\
\hline Costa Rica & 7.3 & 10.1 & 9.7 & 14.8 & 24.1 & 47.3 \\
\hline El Salvador & 2.5 & 2 & 2.4 & 4.5 & 8.05 & 15 \\
\hline Honduras & 0 & 1.4 & 1.4 & 4.15 & 6.8 & 13.2 \\
\hline Guatemala & 1.05 & N.A & 2.1 & 3 & 4.7 & 9.3 \\
\hline Nicaragua & 0.05 & 0.1 & 0.5 & 1.2 & 3.8 & 7.4 \\
\hline
\end{tabular}

Source: ITU (2014A) World Telecommunications Indicators Database

Even before it liberalized its telecommunication sector, Costa Rica already had the highest number of internet users and houses connected. El Salvador has the second most individuals using internet services - a quarter of its population and fifteen percent of connections from households - despite the fact that its universal service fund does not contribute to infrastructural development. Nicaragua, which continues to rely on the World Bank to carry out initiatives, has had the least amount of internet users in the least amount of homes, although it almost doubled its total amount of internet users from 2008 to 2010. This is in part because of FITEL's investment into internet infrastructure, as well as the World Bank's assistance in installing 
"broadband internet points of presence" in 101 of 153 municipalities throughout the country (World Bank, 2012, p. 8).

As internet infrastructures have developed, so too have the quality of connections. Broadband connections, which the ITU classifies as connections starting from $256 \mathrm{~kb} / \mathrm{second}$, offer much faster connections than traditional dial-up internet and thus a faster way to share information. While these services grew in other parts of the world, evidence from the ITU shows that sector liberalization has not greatly affected fixed-line broadband services, given that they saw no considerable growth. Whereas countries like Canada and the US saw penetration rates of 32.5 percent and 28.35 percent respectively, the only country to come close to a penetration rate of ten percent was Costa Rica with 9.3 percent in 2012. This is not surprising since one of the goals of its universal service policy has been to promote broadband internet access. Indeed, shortly after sector liberalization in 2008 , the number of subscriptions rose considerably (Table $5.10)$.

Table 5.10: Fixed-broadband Subscriptions per 100 people

\begin{tabular}{|l|r|r|r|r|r|}
\hline Country & $\mathbf{2 0 0 4}$ & $\mathbf{2 0 0 6}$ & $\mathbf{2 0 0 8}$ & $\mathbf{2 0 1 0}$ & $\mathbf{2 0 1 2}$ \\
\hline Costa Rica & 0.65 & 1.9 & 2.35 & 8.5 & 9.3 \\
\hline El Salvador & 0.5 & 1 & 2 & 2.8 & 3.85 \\
\hline Guatemala & 0 & 0.3 & 0.7 & 1.8 & 1.8 \\
\hline Nicaragua & 0.1 & 0.35 & 0.75 & 1.25 & 1.65 \\
\hline Honduras & 0 & 0 & 0 & 0.01 & 0.8 \\
\hline
\end{tabular}

Source: ITU (2014A) World Telecommunications Indicators Database

On the other hand, El Salvador, which has not used any of FINETs funds, saw little difference in subscriptions, growing only by 3.36 subscriptions per 100 from 2004 to 2012 . However, it still has the second-highest amount of fixed-broadband subscriptions, albeit only 3.84 subscriptions per 100 in 2012. Honduras, the sole country without a universal service fund, ranks last among 
the countries as it has never reached a penetration rate of more than one per 100 people.

Nicaragua and Guatemala, both countries which have sought help from the World Bank, ranked third and fourth respectively in the group of countries. Overall, in the years since their telecommunications sectors were liberalized, there has not been widespread distribution of fixedline broadband services.

However, broadband is also accessible through mobile technologies. Given the popularity of mobile phones within the region, it comes as little surprise that wireless broadband penetration rates are much higher than fixed-line broadband penetration rates, as Table 5.11 illustrates.

Table 5.11: Wireless-broadband subscriptions per 100 people

\begin{tabular}{|c|c|c|c|}
\hline Country & 2010 & 2011 & 2012 \\
\hline Costa Rica & 7.2 & 10.2 & 20.3 \\
\hline Honduras & $\mathrm{N} / \mathrm{A}$ & 4.3 & 8.6 \\
\hline El Salvador & 2.3 & 3.6 & $\overline{5.5}$ \\
\hline Guatemala & 3.7 & 4 & 4.5 \\
\hline Nicaragua & 0.7 & 0.8 & 1 \\
\hline
\end{tabular}

Source: ITU (2014A) World Telecommunications Indicators Database

Costa Rica again leads all countries; between 2011 and 2012, subscription figures increased by 10.1 subscriptions per 100 people. Honduras had the second highest number of subscriptions while El Salvador had the third most. Once again, Guatemala and Nicaragua rank in the bottom of the group despite having World Bank loans supporting their projects. Nicaragua's case is particularly interesting as it had the lowest number of mobile phones per 100 and also the lowest number of wireless-broadband subscriptions. This is again attributed to the lack of competition within the wireless sector, as outlined in previous chapters and above, as well as attempting to implement a universal service policy years after telecom reform. This has given operators more clout in decision making. 
The final indicator I will analyse is the ITU's ICT Development Index (IDI). The IDI index is a tool the ITU has used since its 2009 publication of Measuring the Information Society to rank "countries' performance with regard to ICT infrastructure, use and skills", by compiling data on ICT access, ICT use, and ICT skills (ITU, 2014). In other words, it illustrates how developed a country's telecommunication infrastructure is. The list is comprised of 151 countries. Table 5.12 shows that historically, and by international standards, Central American countries have consistently ranked low on the IDI Index. In fact, the only country to have cracked the top fifty is Costa Rica. Furthermore, Central American countries have, for the most part, seen a decline in ranks over time. This comes even after the region's sectors have undergone privatization and liberalization and also in spite of countries having implemented universal service policies.

Table 5.12: Country IDI Rank in the World

\begin{tabular}{|l|r|r|l|r|r|r|r|}
\hline & \multicolumn{7}{|c|}{ Country Rank in the World } \\
\hline Country & $\mathbf{2 0 0 7}$ & $\mathbf{2 0 0 8}$ & $\mathbf{2 0 0 9}$ & $\mathbf{2 0 1 0}$ & $\mathbf{2 0 1 0}$ & $\mathbf{2 0 1 2}$ & $\mathbf{2 0 1 3}$ \\
\hline Costa Rica & 67 & 69 & N/A & 70 & 71 & 60 & 55 \\
\hline El Salvador & 99 & 101 & N/A & 98 & 103 & 100 & 110 \\
\hline Guatemala & 102 & 108 & N/A & 108 & N/A & N/A & 118 \\
\hline Honduras & 105 & 104 & N/A & 106 & 107 & 110 & 119 \\
\hline Nicaragua & 112 & 113 & N/A & 114 & 113 & 114 & 120 \\
\hline
\end{tabular}

Source: ITU (2009-2014) Measuring the Information Society

On a regional level, the list illustrates Costa Rica's and El Salvador's consistent "successes" as they consistently rank as the top two in the region. Costa Rica's high score attests to two facts: first, it has historically been the regional leader in telecom development, and second, it rolled out its universal service policy at the same time it liberalized its sector in 2008, rather than after, when operators could influence policymaking. Guatemala took the same path as Costa Rica but 
has failed, falling from 102 in 2007 to 118 in 2013. This is attributed to vague targets set out in its universal service policy. The remaining countries have also seen their ranking on the ITU IDI index decline in the post-reform era: El Salvador fell from ninety-nine in 2007 to 110 in 2013; Honduras has fallen since 2007, from 102 to 118 in 2013, and Nicaragua, which has universal service funds at its disposal, has not been able to rise above the $112^{\text {th }}$ spot in the world. This further shows that sector liberalization and enterprise privatization has not done enough to address the quality of ICT infrastructure. El Salvador attests to this as it has not used any of FINET's funds.

\subsection{How Has El Salvador Done?}

El Salvador has a universal service policy in place, but an inactive universal service fund. Funds created by spectrum auctions and sector fines are allocated to universal electricity initiatives. However, this does not mean that the state has not funded telecommunication projects: instead of allocating funds from its universal service fund, FINET, El Salvador tapped into revenues from a fund generated by the sale of its state-run telephone company, FANTEL, to build telecentres.

While El Salvador has fared better than other countries that actually distribute funds from their universal service funds, it could benefit from using funds for infrastructure development. What has resulted is that El Salvador has relied on sector competition to promote universal services for all telecommunication services. Regionally, this has worked to some degree in the sense that, first, on many of the services discussed in this chapter, it provides the second-best penetration rates and subscription rates, in areas such as fixed-line telephone penetration and broadband services, only behind Costa Rica. Second, El Salvador's mobile phone penetration is impressive by any standards as it is over 100 per 100 people. There are three reasons that seem to 
explain this rather positive outcome: first, telecom operators are required to share their networks. Second, El Salvador has five players in its wireless sector, a number which is higher than in the other countries. Third, there is a very high level of the population that relies on cheaper, pre-paid mobile services for mobile telephony. Indeed, this is representative of the region's approach to wireless technology as income inequality is high throughout it (see Table 2.1 in chapter 2).

However, while sector competition has helped develop the wireless mobile sector, it is also obvious that, for other services, sector competition has not yet delivered on the promises that are often touted by the "free market" ethos. While El Salvador has trailed second only to Costa Rica in many services, this has not meant that its service distribution has been anything to boast. For example, as seen in the previous chapter, its fixed-line telephone sector is highly concentrated. Additionally, while its fixed-line broadband rate is second to Costa Rica's, as of 2012, this figure is only 3.84 per 100 people — far below the standards of developed countries. Mobile broadband figures are only slightly better. Moreover, broadband access from home is noticeably low, with only fifteen percent of houses having access in a country where a quarter of individuals use the internet; this is, again, small in comparison to developed countries such as Canada and the US. Additionally, by using the IDI measurement, one can see that El Salvador's telecommunication infrastructure has consistently ranked in the bottom half of the world. Indeed, while sector reforms have allowed for the introduction of new services, the lack of service distribution that existed in ANTEL's era continues in the present day.

Overall, El Salvador's FISDL has not managed FINET well enough to address the issue of the digital divide. Telecommunication services could benefit greatly from FINET funds in addition to having its telecommunication regulator, SIGET, manage and enforce its policies, instead of FISDL. These policies would also need to be updated so that they are tailored toward a 
variety of services, following Costa Rica's model of using FONATEL to develop infrastructure, education, and to create access to broadband services. As stated at the beginning of this chapter, scholars have written that universal services should be re-tooled to meet these needs, especially as telecommunication environments change (Hudson, 2010). Indeed, El Salvador's lack of services and outdated universal service definitions, which are restricted to fixed-line telephony, are a testament to this. Policies should address issues pertaining to sector competition and newer technologies are needed if the country is to further the development of its telecommunication infrastructure to allow more Salvadorians access to services.

Overall, the distribution of services promised at the outset of privatization and liberalization in El Salvador has not yet been met—everyone has access to a mobile phone, but there remains a large difference between access to cheaper pre-paid plans and higher-end postpaid ones. Fixed-line access remains low well into the new millennium, and internet access remains an issue as there is still a vast amount of the population that is not served. Moreover, as Lemus and Villatoro Canales (2009) have found, those who do have access to telecommunication services, specifically internet services, tend to be better-educated and live in the country's populous areas, such as, Antiguo Cuscatlan, Santa Tecla, and its capital San Salvador (p. 87). Trends suggest that these services will continue to be distributed throughout the country; however, because policies are not targeting those who live outside of populous citycentres, they also suggest that no dramatic increases in service uptake are on the horizon.

\subsection{Conclusion}

This chapter has discussed how countries have approached the digital divide through universal service policies. Four of the five countries created universal service funds and policies. 
These were meant to work alongside sector reforms to ensure that communication technology could be accessible to all. Most, however, appear to have been ineffective. Funds were not deployed but diverted; in El Salvador, they went to financing electricity projects. In other countries, specifically in Guatemala, targets were vague rather than crisply stated, which resulted in underachieved goals.

El Salvador's universal service fund was created but was never used to fund telecommunication projects. Moreover, its fund is not managed by its telecommunication operator, but by a government agency that has an eye on broader socio-economic issues. As a result, the country relied on the revenues generated by FANTEL for telecentres, and on sector competition for internet, fixed-line telephony, and wireless telephony. This allowed mobile telephony to spread throughout the country-a trend visible in all five countries as mobile phones have become the most popular communication technology in the region—but did little to aid the spread of fixed-line and internet services. The IDI index speaks to the lack of telecommunication development as many of the countries, including El Salvador, rank in the bottom fifty of the world's most developed telecommunication infrastructures.

Overall, while privatization and liberalization initiatives have helped spread some telecommunication services in the region (specifically, pre-paid mobile telephony), they have, for the most part, failed to provide universal coverage. This chapter has shown that not only should adequate policies be developed alongside privatization and liberalization initiatives if governments to meet public service goals, but also that policymakers must be able to resist pressures from incumbents when creating these policies. Governments which are capable of doing this, i.e. Costa Rica, stand a much better chance at reaching their universal service goals and position themselves better at tackling the digital divide. 


\section{Conclusion: Yesterday's Seeds, Today's Weeds}

This thesis has examined the development of telecommunication services in El Salvador and Central America. It has shown that access to and the use of telecommunications service in Central America, including basic telephone service, internet access and cellphone services, are far lower than in other parts of the world. For example, Central America stands in contrast with Asia, which has seen increases in the level of ICT access within the last 10 years (Oh and Kathuria, 2012). Historically, the issue of access is one that has existed in the eras of pre-reform and post-reform. To address this, the previous chapter has illustrated that policymakers must be robust when working with private sector actors to ensure maximum uptake, even if it means intervening within the sector.

Important to creating these policies is understanding why they are needed. Behind policies and infrastructure lies a very human aspect of the digital divide which carries two consequences for El Salvador and its neighbouring countries. The first of these consequences is economic. As discussed in the introduction of this thesis, scholars such as Ranetta Lawson Mack (2002), Kirk St. Amant (2011), and Anas Taliweh (2011) argue that ICTs are essential to local, national, regional and international economies. Rachael Schwartz (2002) argues that these technologies spill over into professional life and are essential for economic growth. Telecommunication is an essential infrastructure; therefore, for these scholars, the disparity of its access hinders economic progress.

This thesis supports this argument. One need not look further than Central America to make these observations. As Manuel Castells (1996) writes, technologies can drive economic development insofar as the state allows it: the state could choose to accelerate ICT development, bringing economic and social "wellbeing" to a country in only a couple years' time (p. 5). El 
Salvador and other Central American countries have not followed this blueprint; as this thesis has argued, investment into most telecommunication infrastructures has been inadequate and poorly allocated. There are many scholars including St. Amant (2011), Taliweh (2011), and Mack (2002) who support the opinion that ICT access and economic development have a causal relationship. Furthermore, this lack of access within the region has done little to help its economy. Indeed, as the introduction of this thesis has shown, annual GDPs per capita have historically been low in the region: in Central America's early years, military governments made public access to these telecommunication networks difficult. Throughout the post-reform years, weak, late-to-adopt, and often mismanaged universal service funds along with a reliance on market competition did little to spur high levels of investment in the development of telecommunications services. Consequently, such services have done little to assist in economic development.

Secondly, and equally as important, access to ICTs can promote a healthy democracy by facilitating political and social participation. As discussed in the intro of this thesis, Fortunati and Manganelli (2011) demonstrated this trait in their exploration of mobile phone use and social participation. Those who had access to mobile phones were more likely to have larger social networks. Mossberger et al. (2008) arrived at similar findings, concluding that access to and use of the internet facilitated political conversations which affected political attitudes in three separate federal elections. Benkler (2006) also argues that online political discourse has allowed citizens to expose flaws in US electoral systems through the concept of the "Networked Public Sphere" (pp. 225-233). Dias (2012) notes that broadband in the $21^{\text {st }}$ century has made tele-health services possible for those who have difficulty accessing health care. The common trait shared between these findings is that ICTs facilitate communication in ways that improve social 
connections and participation in public life. They provide a medium through which citizens inform themselves and maintain contacts with others in their lives and the broader economy, society and polity in which they live.

In the days of military rule, social participation and use of networks was not a state priority because of restrictions placed on the development and use of telecommunications networks; priority was given to those in the agro-export industry and the military. Engaging in political discourse was even more difficult. This lack of access to communication services was a characteristic shared among many caudillo-led military dictatorships which factored into the creation of civil conflicts and eventually, civil wars. It was not until democratic reforms swept through the region that change in telecommunication sectors began to take root.

However, even after these reforms — which brought telecom liberalization, privatization, and competition — came into effect, the issue of access (or lack thereof) and, as Lemus and Villatoro Canales (2009) have shown, the divide in usage, has persisted in El Salvador and the region. While mobile phone use has proliferated to the point where penetration levels are at their highest in the region's history (as seen in chapter 5), this is where competition's successes in the region stop. Internet, much less broadband, which allows one to access the forums and groups which make up the "Network Public Sphere", is scarce. Clearly, the market on its own has not looked after the public's interest. This is observable when looking at the scarce access to fixedline and broadband services throughout the region and lack of investments into public telephony. Indeed, this is in contrast to a developed country such as Canada, where fixed-line telephones and broadband subscriptions reached 50 per 100 and 32.47 per 100 in 2013. It also contrasts another Latin America, Uruguay, which had penetration rates of 29.77 per 100 for fixed-line telephones and 16.58 per 100 for fixed-line broadband in 2012 (ITU, 2013). This comes as little 
surprise given Central America's relaxed approach to regulation. As Mack (2002) argues, it is rare for market players to increase consumer access to technologies when it does not benefit their self-interests (p. xxii). Thus, there has been a strong need for regulatory bodies to firmly intervene in the Latin American sectors.

Therefore, the digital divide becomes important to discuss because it hinders social and economic development. The case studies of the digital divide in El Salvador and the other Central American countries speak to this. Through a historical analysis, this thesis has shown that the term "digital divide" is not adequate to describe this inequality of access as it has persisted through time, existing even before the advent of digital technologies. The following section discusses three lessons that can be learned from this thesis.

\subsection{Lessons Learned}

The first lesson is that the digital divide in El Salvador and the region is not an issue that appeared overnight. It is one that has evolved over time and which has deep and persistent roots in power struggles; for El Salvador, it is rooted in political decisions made in its long era of military dictatorship. As chapter 3 of this thesis has discussed, access to telecommunication services in the region has, historically, been scarce. El Salvador's early, repressive military dictatorships used telecommunication networks to realize security and economic goals rather than social ones. This was achieved using infrastructure to further agro-exportations, mainly coffee, and in doing so, it restricted public use of telephone and telegraph lines. State repression was one of the main reasons for the country's civil war from 1979 to 1992 between rebel groups and the government. It was not until after the civil war had ended, and after it had inflicting extensive damage to the country's telecom infrastructure, that the state opened the door to sector liberalization and enterprise privatization. 
Indeed, the Salvadorian state, along with the other states in the region, are ones which must live with a legacy of military authoritarianism, corruption, and one which made meager attempts to address public service needs. As discussed in chapter 2 of this thesis, Central American, caudillo-led states followed an authoritarian blueprint, using telecommunications as a means to extend their powers "into the hinterlands" of countries, and furthermore, to their own benefit instead of their societies'. As a result, states neglected to implement robust telecommunication policies to improve infrastructure and its access, and, as time went on, networks deteriorated, resulting in subpar services for citizens. In an attempt to quickly generate state revenues, many Central American states sold their telecommunication enterprises in conjunction with rushed policymaking. Consequently, the states have been weak in regulating their sectors as they have over-relied on competition to meet goals.

The state can be observed here through what Vincent Mosco identifies as the class perspective of the state, where the state becomes a tool for capitalism. Transnational telecommunication firms and international lending institutions have used the state as a tool to expand their operations within Central America. The region currently finds itself relying heavily on European companies to keep their telecommunication networks running and this has unfortunately created an environment which encourages concentration for some service and a severe lack in service diffusion for others. Some countries, such as Guatemala and Nicaragua, continue to rely on The World Bank for help.

This is not a theme present in the post-reform era, but one that has existed since the 1800s: Guatemala promoted coffee oligarchies; Honduras, with the influence of United Fruit Company, promoted banana farming; and Nicaragua, which was the "late telecommunication bloomer" of the region, used telecommunication closely in conjunction with its military. Costa 
Rica is the exception as it introduced democratic reforms earlier than the other countries. As a result, in 1949 its state-owned enterprise, ICE, was named the national monopoly telecommunication and electricity provider. This spread services across this country faster than the four mentioned above, and the effects of this decision are visible in the present day: Costa Rica's internet, fixed-line, and public telephones penetration rates are the highest of the five Central American countries. While its mobile phone penetration is third to El Salvador and Guatemala, it is still well over 100 per 100 people. In other words, peace and good government appear to be critical to the success of a country's ability to meet the communication needs of its citizens.

Second, the role of international lending institutions and foreign investors, particularly American, Mexican, and European investors, have been instrumental in the development of networks before and after telecom reforms. As Jill Hills (2007) has argued, institutions such as the IMF and World Bank, which had been present in all five countries prior to their civil conflicts, saw Latin America as a region to advance their own interests in the expansion of market-based economies and creating new zones of capital investment. Even in the era of postreform, the World Bank continues to have a presence in Guatemala's and Nicaragua's telecom sectors.

As countries looked to rebuild after decades of civil conflict and war, however, lending institutions insisted that various state enterprises, including telecommunication enterprises, be privatised and markets liberalized under the assumption that liberalization would bring about better services. In the process, telecommunication services were separated from the state, and telecommunication regulators were born. In El Salvador, this meant that ANTEL was split into two enterprises, CTE and Intel S.A. The two were then sold to foreign investors, a process 
overseen by the telecommunications regulator, SIGET. Similar initiatives followed in Honduras, Nicaragua, and Guatemala. Honduras has not privatized its state-owned enterprise, however, but this is not because of a lack of attempts - bureaucratic hurdles, political opposition, and lack of investments, particularly right after Hurricane Mitch, have halted every initiative. Costa Rica, on the other hand, resisted sector liberalization until 2008 when it ratified the Central American Free Trade Agreement, arguing that doing so would be to unnecessarily give into pressure from the World Bank. Even today, it continues to operate its state-owned enterprise. In fact, Costa Rica never privatized ICE's fixed-line services.

Early in the process of telecommunications reform, liberalization and privatization were often believed to encourage better services in the region, and initiatives to bring about both were embraced with enthusiasm in the 1980s and early 1990s. After markets were liberalized, foreign investors established themselves as the region's dominant operators. By the mid-2000s, three foreign-owned companies dominated the region's telecommunication landscape: Telefonica, Millicom, and America Movil. Reforms addressed issues related to the digital divide in the region and helped to spread mobile telephony throughout it. However, as seen in chapter 5, promises for better services were not fulfilled, as privatization and liberalization also left other services neglected, such as fixed-line and public payphones in addition to internet services.

The third lesson that flows from such observations is that the role of the state has not diminished in the post-reform era but rather has been transformed. Furthermore, governments must not only work side-by-side with private sector actors to adopt regulatory frameworks in order to meet universal service goals, but they must be able to resist "regulatory capture" by establishing robust frameworks. Most Central American governments have failed to this, and as a result, universal service policies have not yet succeeded in achieving the goals which they had 
initially set out. El Salvador has a universal service policy and a universal service fund, but both are lumped into a fund that addresses telecommunication and electricity issues. Because of this, resources are allocated to electricity projects and not telecom infrastructure development. Instead, El Salvador has opted to rely on competition within the sector to address the digital divide. While market competition has helped spread mobile technology, it has left a hole in access to internet services and fixed-lined telephones throughout the region. As Hudson (2010), Schwartz (1996), and the GSMA (2007) have argued, universal service policies need to address these new technologies. The Central American cases clearly show that mobile ICTs and internet services merit such attention. Tables 6.1 offers a summary of this thesis' findings.

In sum, El Salvador's approach to universal service and telecommunication policy has been insufficient when addressing the issue of the digital divide. It has certainly performed well regionally in terms of wireless, fixed-line, and broadband penetration which is made evident by its consistent ranking at second and third in service distribution among the five countries. However the evidence shows that by global standards, it trails far behind more developed countries and in even some regions with similar development levels, such as Asia. This is important because telecommunications and national development work together; one cannot function without the other. Thus, it is in the country's best interest to address the divide as it plays a part in much larger social and economic issues. Telecommunication policies must be robust to ensure that private sector actors meet universal service goals. As Central American history has shown, the social and economic implications are too large to ignore. 
Table 6.1: Summary of Findings

\begin{tabular}{|c|c|c|c|}
\hline & $\begin{array}{l}\text { Services covered under Universal } \\
\text { Service Policy }\end{array}$ & Projects & $\begin{array}{l}\text { On pace to meet universal service } \\
\text { objectives? }\end{array}$ \\
\hline Costa Rica & $\begin{array}{l}\text { Flexible: applicable to any } \\
\text { telecommunication service regulated } \\
\text { under the telecommunication law. }\end{array}$ & $\begin{array}{l}\text { 2013: With Telefonica, it aims } \\
\text { to provide internet and phone } \\
\text { services to "over } 4,000 \text { people } \\
\text { and } 1,200 \text { students" in the } \\
\text { Limon province. } \\
\text { 2013: SUTEL announces it will } \\
\text { hold auctions to service nine } \\
\text { municipalities within the Limon } \\
\text { province and would allocate US } \\
\text { \$26.7 million to do so. }\end{array}$ & - Yes \\
\hline El Salvador & $\begin{array}{l}\text { Fixed-line telephones/public } \\
\text { payphones }\end{array}$ & $\begin{array}{l}\text { No funds are used towards } \\
\text { telecommunication projects }\end{array}$ & - $\mathrm{No}$ \\
\hline Guatemala & $\begin{array}{l}\text { Telephone services in rural/low } \\
\text { income areas }\end{array}$ & $\begin{array}{l}\text { 2005: US } \$ 8 \text { dollars toward pay } \\
\text { and residential telephones in } \\
2000 \text { population centres. By the } \\
\text { end of the project, only } 20 \% \text { of } \\
\text { phones actually worked. } \\
\text { 2006: World Bank loan over ten } \\
\text { years to bring } 5,234 \text { payphones, } \\
18,285 \text { private lines, and } 288 \\
\text { internet centres at a cost of US } \\
\$ 25.7 \text { million. }\end{array}$ & - $\mathrm{No}$ \\
\hline Nicaragua & $\begin{array}{l}\text { Flexible: "telecommunication } \\
\text { projects [including public telephone } \\
\text { networks, call centres, telecentres, } \\
\text { internet], ICTs, and postal services" }\end{array}$ & $\begin{array}{l}\text { 2005: "The Rural } \\
\text { Telecommunication Project", } \\
\text { with the help from the World } \\
\text { Bank. Two part project: Part } \\
\text { one aimed to increase } \\
\text { payphones and internet accesses } \\
\text { in rural areas at a price of US }\end{array}$ & - $\mathrm{No}$ \\
\hline
\end{tabular}




\begin{tabular}{|c|c|c|c|}
\hline & & $\begin{array}{l}\$ 400,000 \text {. Mixed results: } \\
\text { mobile phone access increased } \\
\text { but payphone access did not. } \\
\text { Part two aimed to increase } \\
\text { public payphones and internet } \\
\text { access in municipal heads. } \\
\text { Project completion date was } \\
\text { pushed back to } 2015 \text {. }\end{array}$ & \\
\hline Honduras & N/A & $\mathrm{N} / \mathrm{A}$ & $\mathrm{N} / \mathrm{A}$ \\
\hline
\end{tabular}

\begin{tabular}{|c|c|c|c|c|c|c|c|c|c|c|c|}
\hline & \multicolumn{2}{|c|}{ Regulator } & \multicolumn{2}{|c|}{$\begin{array}{c}\text { Universal Service } \\
\text { Fund }\end{array}$} & \multirow{2}{*}{$\begin{array}{l}\text { Fund } \\
\text { Managed } \\
\text { by } \\
\text { Regulator? }\end{array}$} & \multicolumn{2}{|c|}{$\begin{array}{l}\text { State-Owned } \\
\text { Enterprise }\end{array}$} & \multicolumn{4}{|c|}{ Service Uptake per 100 users (2012) } \\
\hline & Name & $\begin{array}{c}\text { Year } \\
\text { Created }\end{array}$ & Name & $\begin{array}{l}\text { Year } \\
\text { Created }\end{array}$ & & \begin{tabular}{l|} 
Fixed- \\
Line \\
\end{tabular} & Mobile & Mobile & Fixed-line & $\begin{array}{l}\text { Broadband: } \\
\text { Fixed-line }\end{array}$ & $\begin{array}{l}\text { Broadband: } \\
\text { Wireless }\end{array}$ \\
\hline Costa Rica & SUTEL & 2008 & FONATEL & 2008 & Yes & Yes & No & 111.9 & 20.7 & 9.3 & 20.3 \\
\hline El Salvador & SIGET & 1996 & FINET & 1998 & No: FISDL & No & No & 137.3 & 16.8 & 3.85 & 5.5 \\
\hline Guatemala & SIT & 1996 & FONDETEL & 1996 & Yes & No & No & 137.8 & 11.6 & 1.8 & 4.5 \\
\hline Nicaragua & TELCOR & 1996 & FITEL & 2004 & Yes & No & No & 86.1 & 5 & 1.65 & 1 \\
\hline Honduras & CONATEL & 1995 & None & N/A & N/A & Yes & No & 92.9 & 7.7 & 0.8 & 8.6 \\
\hline
\end{tabular}




\section{References}

Alleman, J., Rappoport, P., Banerjee, A. (2010) “Universal Service: A New Definition?” In Telecommunications Policy. 34(1-2). pp. 86-97.

America Movil (2014) “About America Movil”. Accessed at http://www.americamovil.com/amx/about/footprint? $\mathrm{p}=28$

Amill, V. (1947) Development of Transportation and Telecommunication in El Salvador. M.A. in Social Sciences Dissertation. University of Chicago: Chicago.

Ansorena, C. (2007) “Competencia Y Regulación En La Banca: El Caso De Nicaragua.” Written for IDCR/CEPAL's Reforzando la competencia en el Istmo Centroamericano: políticas e instituciones nacionales, coordinación regional y participación en negociaciones internacionales Project.

Argumedo, P. (2007) "Competencia y regulación en las telecomunicaciones: El caso de El Salvador.” Written for IDCR/CEPAL's Reforzando la competencia en el Istmo Centroamericano: políticas e instituciones nacionales, coordinación regional y participación en negociaciones internacionales Project.

Barcena, A. (2011) “Spreading the Wealth” In Finance \& Development. 48 (1). Pp. 20-21.

Barja, G. and Gigler, B. (2007) "The Concept of Information Poverty and How to Measure it in the Latin American Context”. In Galperin, H., Mariscal, K. Digital Poverty: Latin American and Caribbean Perspectives. Pp. 12-29. International Development Research Centre: Ottawa.

Bauer, J. (2010) "Transformations of the State in Telecommunications". In Papathanassopolous, S., Negrine, R., Communication Policy: Theory and Issues. Pp. 148-165. New York: Palgrave Macmillan

Bauer, J. 1995) “Alternatives to Private Ownership.” In Mody, B., Johannes, B.M., Straubhaar, J.D. (eds.) Telecommunications Politics: Ownership and Control of the Information Highways in Developing Countries. pp. 261-286. Lawrence Erlbaum Associates: New Jersey.

Becerra and Mastrini (2012) "Media Ownership, Oligarchies, and Globalization: Media Concentration in South America". In Winseck, D., Jin, D., The Political Economies of Media: The Transformation of the Global Media Industries. Pp. 66-83. New York: Bloomsbury.

Benitez, J. (2014) "Pluralism, Digitalization and the Contemporary Challenges of Media Policy in El Salvador". In Guerrero, M., Marquez-Ramirez, M., Media Systems and Communication Policies in Latin America. Pp. 122-138. Palgrave-MacMillan: UK.

Benkler, Y. (2006) The Wealth of Networks: How Social Producation Transforms Markets and Freedom. Yale University Press. 
Black, G. (1984) Garrison Guatemala. New York: Monthly Review Press.

Bull, B. (1999) "New Regionalism in Central America" In Third World Quarterly. 20 (5) pp. 957-970.

Bull, B. (2005) Aid, Power, and Privatization: The Politics of Telecommunication Reform in Central America. UK: Edward Elgar Publishing.

Business News America (2002, Jaunary 17) “LatAm Telecoms Weekly Wrap"

Casanueva-Reguarts, C. (2013) “Mexico's universal telecommunications service Policies and regulatory environment in an International perspective, 1990-2010." In Journal of Information Policy. 3. pp. 267-303.

Castells, M. (1996) "Prologo La Red y El Yo" In La Era De La Información. Economía, Sociedad Y Cultura. Vol 1. Pp. 1-18. Mexico: Siglo XXI.

Castree, N., Kitchin, R., Rogers, A. (2013) A Dictionary of Human Geography. Oxford University Press: UK.

CEPAL (2015) Databases and Statistical Publications. Accessed at http://estadisticas.cepal.org/cepalstat/WEB_CEPALSTAT/Portada.asp?idioma $=\mathrm{i}$

Chapuis, R., Joel, A. (2003) 100 Years of Telephone Switching, Part 1. Amsterdam: IOS Press.

Ching, E. F. (2014) North Dame. Indiana: University of Notre Dame Press.

Clegern, W. (1994) Origins of liberal dictatorship in Central America: Guatemala, 1865-1873. Niwot, Colorado: University Press of Colorado

Compaine, B. M. (2001) “Information Gaps: Myth or Reality?" In Compaine, B. M (ed.) The Digital Divide: Facing a Crisis or Creating a Myth? Pp. 105-118. Massachusetts: MIT Press.

Compaine, B. M., and Weinraub, M. (2001) "Universal Access to Online Services: An Examination of the Issue." In Compaine, B. M (ed.) The Digital Divide: Facing a Crisis or Creating a Myth? Pp. 147-178. Massachusetts: MIT Press.

Conatel (2013) Registro de Operadores - Operadores del Servicio PCS

Decree 341 (1976) "La Organica de la Empresa Hondurena de Telecomunicaciones". Obtained from La Gaceta: Diario Oficial de la Republica de Honduras, Num. 21.907.

Decree 354 (1998) Ley Del Fondo De Inversión Nacional En Electricidad Y Telefonía

Decree 94-96 (1996) Ley General de Telecomunicaciones 
Decree no. 1053 (1982) "Ley Organica Del Instituto Nicaragüense De Telecomunicaciones Y Correos (Telcor)"

Decree no. 244-98 (1999) "Decreto no. 244-98, Del 19 De Septiembre De 1998, Reformado Por El Decreto no. 89-99 Del 30 De Junio De 1999"

Decree no. 370 (1962) "Ley De La Administracion Nacional De Telecomunicaciones"

Decree no. 808 (1996) "Ley De Telecomunicaciones"

Decree no. 84 (2004) Reglamento De Administración Y Financiamiento Del Fondo De Inversión De Telecomunicaciones (FITEL)

Decree no. 8642 (2008) Ley General De Telecomunicaciones

Decree no. 94-96 (Guatemala) "Ley General de Telecomunicaciones"

Diario Oficial Num. 259 (1887) "Telefono A Santa Ana"

Dias, M. (2012) “Australia's Project for Universal Broadband Access: From Policy to Social Potential". In First Monday. 17(9) Accessed at http://firstmonday.org/ojs/index.php/fm/article/view/4114/3299

Direccion General de Estadistica y Censos (DIGESTYC) (2008) VI Censo De Poblacion Y V De Viviendo 2007. Accessed at http://www.signalstelecomnews.com/

Dow Jones International News (2003) “America Movil Widens Regional Reach with CTE Acquisition"

Drale, C. (2010) “The United Fruit Company and Early Radio Development". In Journal of Radio \& Audio Media. 17(2) pp. 195-210.

El Diario de Hoy (2005, October 20) "Intelfon inicia operaciones en el país"

El Pais (2004, March 9) "Telefónica cierra la compra de BellSouth en Latinoamérica por 4.731 millones"

El Salvador Government (1939) Constitucion Politica de la Republica de El Salvador. Accessed at http://www.isd.org.sv/isd/index.php/versiones-de-constitucion-de-la-republica-de-elsalvador/82-isd/democracia/estudios-y-publicaciones/constituciones/377-constitucion-de-larepublica-de-el-salvador-ano-1939

FBI (2009) "Latin Node Inc., Pleads Guilty to Foreign Corrupt Practices Act Violation and Agrees to Pay \$2 Million Criminal Fine”. Accessed at: http://www.fbi.gov/miami/pressreleases $/ 2009 / \mathrm{mm} 040709 . \mathrm{htm}$ 
FISDL (2014) “Historia del Fondo de Inversión Social para el Desarrollo Local - FISDL”. Accessed at http://www.fisdl.gob.sv/institucion/marco-institucional/historia\#.VXG1289Viko

Fortunati, L. and Manganelli, A. M. (2011) "Social Participation and Mobile Communication." In Katz, J. E. (ed.) Mobile Communication. Pp. 273-290. Transaction Publishers: New Brunswick.

Fortunati, L. and Manganelli, A. M. (2011) "Social Participation and Mobile Communication." In Katz, J. E. (ed.) Mobile Communication. Pp. 273-290. Transaction Publishers: New Brunswick.

Funes, B. (2002) Telecommunications in Central America: El Salvador, Honduras, Guatemala, Nicaragua and Costa Rica the shift from public to private, the "development" connection, and the rise of wireless communications. M.A. in Communication Thesis. Carleton University: Ottawa.

George Mason University (2006) "Professor Thomas W. Hazlett”. Accessed at http://mason.gmu.edu/ thazlett/

GSMA (2007) "How Mobile Can Bring Communications to All (A study by IntelcomNovember 2007).

GSMA (2007) "How Mobile Can Bring Communications to All (A study by IntelcomNovember 2007).

Haq, F. (1996, December 5) "El Salvador-Labour: Workers Criticise Sweatshops, Government”. Inter Press Service News Agency.

Harvey, D. (2003) “Canada's Permeable Fordist Telecommunication Regime”. In Rideout, V. Continentalizing Canadian Telecommunications: The Politics of Regulatory Reform. Pp. 30-46).

Herrera, A. (1996) "Nicaragua" in Noam, E., Telecommunications in Latin America. Pp. 52-59. New York: Oxford University Press.

Hilbert, M. (2009) "When Is Cheap, Cheap Enough To Bridge The Digital Divide? Modelling Income Related Structural Challenges of Technology Diffusion In Latin America." In World Development. 38(5) pp. 756-770.

Hilbert, M. (2011) “The End Justifies The Definition: The Manifold Outlooks On The Digital Divide And Their Practical Usefulness For Policy-Making.” In Telecommunications Policy. 35, pp. 715-736.

Hills, J. (2007) Telecommunications and Empire. Chicago: University of Illinois Press 
Hitsherich, J. D., Roldan Perea, J. M. (2007) "Institutional Design Of The Regulator In Latin America And The Caribbean." In Galperin, H. (eds.) Digital Poverty: Latin America And The Caribbean Perspectives. pp. 79-94. International Development Research Centre: Ottawa.

Hudson, H (2010) "Defining Universal Service Funds: Are They Accelerators of Anachronisms". In Intermedia. 31 (1). pp. 16-21.

Hudson, H. (1997) Global Connections: International Telecommunications Infrastructure and Policy. Pp. 207-232. USA: Van Nostrand Reinhold.

Huurdeman, A. (2003) The Worldwide History of Telecommunications. John Wiley \& Sons: New York.

Iosifidis, P. (2011) Global Media and Communication Policy. Palgrave Macmillian: UK.

ITU (1949) "General Telephone Statistics Compiled From Official Documents By The General Secretariat of the International Telecommunication Union: Year 1948". Geneva.

ITU (2009) Measuring the Information Society

ITU (2010) Measuring the Information Society

ITU (2011) Measuring the Information Society

ITU (2012) Measuring the Information Society

ITU (2013) Measuring the Information Society

ITU (2014a) The World Telecommunication/ICT indicators.

ITU (2014b) Measuring the Information Society

James, J. (2003) Bridging the global digital divide. Northampton, MA: Edward Elgar Publishing.

John, R. (2010) Network Nation: Inventing American Telecommunication. Cambrige, MA: The Belknap Press of Harvard University Press.

John, R. (2012) "From Franklin to Facebook: The Civic Mandate for Communications." In S. Conn (ed.). To Promote the General Welfare: The Case for Big Government (pp. 156-172). New York: Oxford University.

Katz, R. L., Callorda, F., Koutroumpis, P. (2013) "The Latin American Path Towards Digitization.” In Info. 15(3), pp. 6-24.

King, J. L. (2011) “Mobile Communication and Socio-Technical Change.” In Katz, J. E., Mobile Communication. Pp. 37-61.Transaction Publishers: New Brunswick 
King, J. L. (2011) “Mobile Communication and Socio-Technical Change." In Katz, J. E., Mobile Communication. Pp. 37-61.Transaction Publishers: New Brunswick

Kunigami, A. M. (2009) "Output-Based Aid in Telecommunications: New Models for Universal Access in Latin America." In OBApproaches. Accessed at

https://openknowledge.worldbank.org/bitstream/handle/10986/10996/476370BRI0OBAp10Box3 38858B01PUBLIC1.pdf? sequence $=1$

La Nacion (1996a) "Elecciones En El Salvador"

La Nacion (1996b, March 19) "Empleados Rechazan Privatización De Empresa De Telecomunicaciones"

La Nacion (1996c, April 26) "Investigarán a militares por posible hurto de líneas”

La Nacion (2011, June 22) "Sutel: Telefónica y Claro pueden empezar a dar servicios"

La Nacion (2013, July 11) “Telefonica de Costa Rica Gana Primera Adjudicacion de Fonatel”

Lehoucq, F. (2012) The Politics Of Modern Central America: Civil War, Democratization, And Underdevelopment. Cambridge: Cambridge University Press.

Lemus, M.A., Villatoro Canales, C.V. (2009) La Brecha Digital en El Salvador: Causas y Manifestaciones. Thesis for Licentiate in Economics. Universidad Centroamericana Jose Simeon Canas, Antiguo Cuscatlan: El Salvador.

Leonard, T. (2011) The History of Honduras. Santa Barbara, California: Greenwood

Lessig, L. (2006) Code 2.0. Cambridge, MA: Basic Books.

Lundell, J. E. (1954) “Telecommunications in El Salvador". Report prepared for the World Bank.

Mack, R.L. (2002) The Digital Divide. United Kingdom: Blackwell Publishing.

Manzetti, L. (2000) “The Political Economy of Regulatory Policy”. In Regulatory Policy in Latin America: Post-Privatisation Realities. pp. 83-108. Miami: University of Miami.

Mariscal, J., Bonina C., Luna, J., (2007) “New Marker Scenarios in Latin America.” In Galperin, H. (eds.) Digital Poverty: Latin America And The Caribbean Perspectives. pp. 55-78. International Development Research Centre: Ottawa.

Mariscal, J., Galperin H. (2007) “Introduction”. In Mariscal J, Galperin, H. Digital Poverty: Latin American and Caribbean Perspectives. pp. 8-11. Ottawa: International Development Research Centre. 
McIver, W., Birdsall, W., Rasmussen, M. (2003) “The Internet and the Right to Communicate”. In First Monday. 8 (12). Accessed at http://firstmonday.org/ojs/index.php/fm/article/view/1102/1022

Melody, W.H. (1995) "Privatization and the Developing Countries." In In Mody, B., Johannes, B.M., Straubhaar, J.D. (eds.) Telecommunications Politics: Ownership and Control of the Information Highways in Developing Countries. pp. 249-260. Lawrence Erlbaum Associates: New Jersey.

Millicom (2014) "Latin America". Accessed at http://www.millicom.com/where-weoperate/latin-america/

Mitchell, B. (2007) International Historical Statistics, $\sigma^{\text {th }}$ Edition. Palgrave Macmillan: Basingstoke

Mody, B. and Tsui, L (1995) "The Changing Role of the State". In Telecommunications Politics: Ownership and Control of the Information Highways in Developing Countries. Pp. 179-200.

New Jersey: Lawrence Erlbaum Associates.

Mosco, V. (1988) "Toward a Theory of the State and Telecommunications Policy." In Journal of Communication. 38(1), pp. 107-124.

Mosco, V. (2006) The Political Economy of Communication, $2^{\text {nd }}$ Edition. SAGE Publications: London.

Mossberger, K., Tolbert, C., McNeal, R. (2008) Digital Citizenship: The Internet, Society, and Participation. Cambridge: MIT Press

Noam, E. (1994) "Beyond liberalization III: Reforming Universal Service" In Telecommunicaions Policy. 18(9). pp. 687-704.

Noam, E. (eds.) (1998) Telecommunications in Latin America. Oxford: Oxford University Press.

Oh, K., Kathuria, V (2012) "Digital-divide Across Asian Countries: Is the Convergence Robust?" In Korea and the World Economy. 13(3) pp. 451-475.

Ordonez, J. (2009) The Republic Of Costa Rica: A Case Study On The Process Of Democracy Building. Kingston, Ontario: Queens University

Penton Business Media Inc. (1990, May 28) "Nicaragua seeks telephone help"

Petrazzini (1993) The Political Economy Of Telecommunication Reform In Developing Countries: Privatization And Liberalization In Comparative Perspective. Doctoral Dissertaion. University of California: San Diego. 
Petrazzini, B. (1996) Global Telecom Talks: A Trillion Dollar Deal. Institute for International Economics: Washington DC.

Primo Braga, C.A., Ziegler, V. (1998) "Telecommunications in Latin America and the Carribean: The Role of Foreign Capital." In The Quarterly Review of Economics and Finance. 38 (3) pp. 409-419.

Rankin, M. (2012) The History of Costa Rica. Greenwood: Santa Barbara, California.

Raventos (1998) “Telecommunications in Central America," Development Discussion Paper no. 684. Harvard University.

Reagan, R. (1985) “The United States on the Offensive in Central American in the 1980s". In Peckenham, N., Street, A., (eds.) Honduras: Portrait of a Captive Nation. New York: Praeger.

Research Directorate, Immigration and Refugee Board, Canada (1997) "El Salvador: Information on the privatization of the National Telecommunications Administration (ANTEL), the position of its workers' union, and on conflicts union members may have experienced as a result of their union's position, 1996-97”. Accessed at http://www.refworld.org/docid/3ae6ac5543.html

Reuters (1998, July 24) "France Telecom wins El Salvador phone sale”

Reuters (1999, October 22) "Spain's Telefonica in Guatemala cell phone venture”

Reuters (2010, July 1) "Millicom says to consolidate Honduras ops"

Revista Envio (1995, December) "Privatizing TELCOR: Not the Only or Best Solution"

Ricciardi, J. (1991) "Economic Policy” In Walker, T., Revolution and Counterrevolution in Nicaragua. pp. 247-274. Colorado: Westview Press.

Rivera, E. (2008) "Models of Privatization and Development of Competition in Telecommuications in Central America and Mexico.” In Schatan, C., and Rivera, E. (eds.) Competition Policies in Emerging Economics. pp. 49-96. New York: Springer.

Russell, S. (1998) "Guatemala" in Noam, E. (ed.), Telecommunications in Latin America. pp. 4451. Oxford University Press: New York

Salazar, A. (1987) El Salvador: Elementos de Su Historia y sus Luchas (1932-1985). Caracas: Fondo Editorial Tropykos.

Salzman, R., Albarran, A. B. (2011) “Internet Use In Latin America.” In Palabra Clave. 14(2) pp. 297-313.

SBWire (2014, March 21) "Honduras - Hondutel Expected Continued Losses for 2013 Despite Management Shakeup, New Report Launched" 
Schwartz R. E. (1996) Wireless Communications in Developing Countries: Cellular and Satellite Systems. Archtech House: Boston.

Servon L.J. (2002) Bridging the Digital Divide: Technology, Community, and Public Policy. Blackwell Publishing: UK

SIGET (2009) Mision y Vision. Accessed at

http://www.siget.gob.sv/index.php/institucion/marco-institucional/historia

SIGET (2013) "Las Telecomunicaciones en El Salvador.” Accessed at http://www.siget.gob.sv/index.php/temas/telecomunicaciones/resena-historica/1955

SIGET (2013) Boletín Estadístico de Telecomunicaciones Año 2013

Simon, J.M. (1987) Guatemala: Eternal Spring, Eternal Tyranny. New York: Norton

Singh, J. P. (1999) Leapfrogging development? : The Political Economy of Eelecommunications Restructuring. Albany: State University of New York Press.

Sinha, N. (1995) "Regulatory Reform: An Institutional Perspective" In Mody, B., Johannes, B.M., Straubhaar, J.D. (eds.) Telecommunications Politics: Ownership and Control of the Information Highways in Developing Countries. pp. 287-308. Lawrence Erlbaum Associates: New Jersey

SIT (2013) “Líneas Móviles por Operador, Telefonía Pública y Comunitaria, Líneas Fijas por Departamento y Municipio, por Operador"

St. Amant, K. (2011) Globalization and the Digital Divide: Understanding the Connections Between Technology and Communication in a Global Context. In St. Amant, K. and Olaniran, B. (Eds.), Globalization and the Digital Divide. pp. 1-12. Amherst: Cambria Press.

Statscan (n. d.) Estimated population of Canada, 1605 to Present. Accessed at http:/www.statcan.gc.ca/pub/98-187-x/4151287-eng.htm

Stern P.A., Townsend, D.N (2007) New Models for Universal Access to Telecommunications in Latin America: Lessons from the Past and Recommendations for a New Generation of Universal Access Programs for the 21st Century. Report prepared for REGULATEL.

Sunday Business Post (2006, October 1) “Digicel invests \$100m in Jamaican operation”

SUTEL (2008) “Ley De Telecomunicaciones”

SUTEL (2013) Informe Anual De Administración Del Fondo Nacional De Telecomunicaciones (FONATEL)

SUTEL (2013) Informe De Labores Costa Rica: 2013 
SUTEL (2014) Informe Semestral de Administración del Fondo Nacional de Telecomunicaciones (FONATEL, 1-2014)

Sutherland, E. (2012) "Corruption in Telecommunications: Problems and Remedies" In Info. 14 (1) pp. 4-19.

Tabora (2007) "Competencia y regulación en las telecomunicaciones: el caso de Tawileh, A. (2011) "Wireless Networking Bridges the Digital Divide in Africa". In St. Amant, K. and Olaniran, B. A. Globalization and The Digital Divide. pp. 89-102. Amherst: Cambria Press

Telcor (2013) "Participación de Mercado de los Operadores del Servicio de Telefonía Celular por Año"

Telefonica (2014) "History". Accessed at http://www.telefonica.com/en/about_telefonica/html/history/2000-2005.shtml

Telefonica (2014) Audit Report, Consolidated Annual Financial Statements, And Consolidated Management Report All For The Year Ended December 31, 2014

Telegraph Journal and Electric Review (1882) The Central and South American Telegraph Company's Cables.

Trucco, D. (2013) "The Digital Divide in the Latin American Context." In Muschert, G.W. and Ragnedda M., The Digital Divide: The Internet And The Social Inequality In International Perspective. Pp. 274-290. Routledge.

Tsounta, E., Osueke, A. (2014) "What is Behind Latin America's Declining Income Inequality?" Paper written for the International Monetary Fund.

UNDP (2013) “Income Gini Coefficient”. Accessed at http://hdr.undp.org/en/content/incomegini-coefficient

United Nations (1992) "Letter dated 27 January 1992 from the Permanent Representative of El Salvador to the United nations addressed to the Secretary-General"

United Nations (n. d.) "World Population Prospects: The 2012 Revision". Accessed at http://esa.un.org/unpd/wpp/unpp/panel_population.htm

Urizar, C. (2005) "Competencia y regulación en las telecomunicaciones: el caso de US Census Bureau (2014) "The 1950 Census". Accessed at https://www.census.gov/history/www/through_the_decades/fast_facts/1950_fast_facts.html 
US Code (1934) Communications Act of 1934-47 U.S. Code § 151. Accessed at the Cornell University Law School: Legal Information Institute at http://www.law.cornell.edu/uscode/text/47/151

Wall Street Journal (22 June, 2004) "Mexico's America Movil Buys Honduran Phone Carrier Megatel"

Wellenius, B. (2000) "Regulating the telecommunications Sector: The Experience of Latin America." In Manzetti, L. (ed.) Regulatory Policy in Latin America. Pp. 189-241. Miami: NorthSouth Center Press.

White, C. (2009) The History of El Salvador. London: Greenwood Publishing Group.

Williams, P. J, Walter, K. (1997) Militarization and Demilitarization in El Salvador's Transition to Democracy. University of Pittsburgh Press: Pittsburgh.

World Bank (1963) "Report and Recommendations of the President to The Executive Directors on a Proposed loan to the Administracion Nacional de Telecomunicaciones in The Republic of El Salvador"

World Bank (1963b) "Report And Recommendations Of The Presidentto The Executive Directors On A Proposed Loan To The Instituto Costarricense De Electricidad In The Republic Of Costa Rica"

World Bank (1971) "Appraisal of the First Telecommunications Project of the Empresa Guatemalteca De Telecomunicaciones (GUATEL) Guatemala"

World Bank (1972) "Appraisal of the Second Telecommunications Project of The Administracion Nacional De Telecomunicaciones (ANTEL) El Salvador"

World Bank (1972) "Appraisal of the Second Telecommunications Project of the Administracion Nacional de Telecomunicaciones (ANTEL), El Salvador"

World Bank (1978) "Staff Appraisal Report Costa Rica Instituto Costarricense De Electricidad (ICE) National Telecommunications System (NTS) Fifth Telecommunications Project"

World Bank (1983) "Project Completion Report Costa Rica: Fourth Telecommunications Project (Loan 1006-Cr)"

World Bank (1986) "Project Completion Report: Guatemala, Second Telecommunications Project (Loan 1104-Gu)"

World Bank (1990) "Project Completion Report: El Salvador Third Telecommunications Project (Loan 1570-ES)" 
World Bank (1994) "Report And Recommendation Of The President Of The International Development association To The Executive Directors On A Proposed Second Economic Recovery Credit In An Amount Equivalent To SDR 42.5 Million And An IDA Reflows Supplemental Credit In An Amount Equivalent to SDR 5.36 Million To The Republic Of Nicaragua"

World Bank (2006a) "Project Information Document (PID) Appraisal Stage - Nicaragua"

World Bank (2006b) "Documento De Evaluación De Proyecto Sobre Una Propuesta De Préstamo Por El Monto De Us\$ 30 Millones A La República De Guatemala Para Un Proyecto De Apoyo Al Programa De Desarrollo Económico Desde Lo Rural"

World Bank (2012) "Project Paper On A Proposed Additional Credit In The Amount Of SDR 3.3 Million (Us\$5 Million Equivalent) To The Republic Of Nicaragua For The Rural Telecommunications Project”

World Bank (2014) “Implementation Status \& Results Nicaragua Rural Telecom (P089989)"

World Bank (2015) "World Development Indicators". Accessed at http://databank.worldbank.org/data/views/variableSelection/selectvariables.aspx?source=worlddevelopment-indicators

Xavier, P. (2008) “From universal service to universal network access?” In Info. 10 (5-6) pp. 2032. 